The University of Maine

\title{
DigitalCommons@UMaine
}

Earth Science Faculty Scholarship

Earth Sciences

8-1-2008

\section{Recommended Nomenclature for the Sapphirine and Surinamite Groups (Sapphirine Supergroup)}

Edward S. Grew

University of Maine - Main, esgrew@maine.edu

U. Hålenius

M. Pasero

J. Barbier

Follow this and additional works at: https://digitalcommons.library.umaine.edu/ers_facpub

Part of the Earth Sciences Commons

\section{Repository Citation}

Grew, Edward S.; Hålenius, U.; Pasero, M.; and Barbier, J., "Recommended Nomenclature for the Sapphirine and Surinamite Groups (Sapphirine Supergroup)" (2008). Earth Science Faculty Scholarship. 168.

https://digitalcommons.library.umaine.edu/ers_facpub/168 


\title{
Recommended nomenclature for the sapphirine and surinamite groups (sapphirine supergroup)
}

\author{
E. S. Grew ${ }^{1}$, U. Hålenius ${ }^{2}$, M. Pasero ${ }^{3}$ and J. Barbier ${ }^{4}$ \\ ${ }^{1}$ Department of Earth Sciences, University of Maine, 5790 Bryand Research Center, Orono, 04469-5790 Maine, \\ USA \\ ${ }^{2}$ Department of Mineralogy, Swedish Museum of Natural History, Box 50007, SE-104 05 Stockholm, Sweden \\ ${ }^{3}$ Dipartimento di Scienze della Terra, Università di Pisa, Via S. Maria 53, I-56126 Pisa, Italy \\ ${ }^{4}$ Department of Chemistry, McMaster University, Hamilton, Ontario, Canada L8S 4M1
}

[Received 3 September 2008; Accepted 13 October 2008]

\section{ABSTRACT}

Minerals isostructural with sapphirine- $1 A$, sapphirine- $2 M$, and surinamite are closely related chain silicates that pose nomenclature problems because of the large number of sites and potential constituents, including several $(\mathrm{Be}, \mathrm{B}, \mathrm{As}, \mathrm{Sb})$ that are rare or absent in other chain silicates. Our recommended nomenclature for the sapphirine group (formerly aenigmatite group) makes extensive use of precedent, but applies the rules to all known natural compositions, with flexibility to allow for yet undiscovered compositions such as those reported in synthetic materials. These minerals are part of a polysomatic series composed of pyroxene or pyroxene-like and spinel modules, and thus we recommend that the sapphirine supergroup should encompass the polysomatic series. The first level in the classification is based on polysome, i.e. each group within the supergroup corresponds to a single polysome. At the second level, the sapphirine group is divided into subgroups according to the occupancy of the two largest $M$ sites, namely, sapphirine $(\mathrm{Mg})$, aenigmatite $(\mathrm{Na})$, and rhönite $(\mathrm{Ca})$. Classification at the third level is based on the occupancy of the smallest $M$ site with most shared edges, M7, at which the dominant cation is most often Ti (aenigmatite, rhönite, makarochkinite), $\mathrm{Fe}^{3+}$ (wilkinsonite, dorrite, høgtuvaite) or $\mathrm{Al}$ (sapphirine, khmaralite); much less common is $\mathrm{Cr}$ (krinovite) and $\mathrm{Sb}$ (welshite). At the fourth level, the two most polymerized $T$ sites are considered together, e.g. ordering of $\mathrm{Be}$ at these sites distinguishes høgtuvaite, makarochkinite and khmaralite. Classification at the fifth level is based on $X_{\mathrm{Mg}}=\mathrm{Mg} /\left(\mathrm{Mg}+\mathrm{Fe}^{2+}\right)$ at the $M$ sites (excluding the two largest and $\left.M 7\right)$. In principle, this criterion could be expanded to include other divalent cations at these sites, e.g. Mn. To date, most minerals have been found to be either Mg-dominant $\left(\mathrm{X}_{\mathrm{Mg}}>0.5\right)$, or $\mathrm{Fe}^{2+}$-dominant $\left(X_{\mathrm{Mg}}<\right.$ 0.5 ), at these $M$ sites. However, $X_{\mathrm{Mg}}$ ranges from 1.00 to 0.03 in material described as rhönite, i.e. there are two species present, one Mg-dominant, the other $\mathrm{Fe}^{2+}$-dominant. Three other potentially new species are a Mg-dominant analogue of wilkinsonite, rhönite in the Allende meteorite, which is distinguished from rhönite and dorrite in that $\mathrm{Mg}$ rather than $\mathrm{Ti}$ or $\mathrm{Fe}^{3+}$ is dominant at $M 7$, and an $\mathrm{Al}-$ dominant analogue of sapphirine, in which $\mathrm{Al}>\mathrm{Si}$ at the two most polymerized $T$ sites $v s$. $\mathrm{Al}<\mathrm{Si}$ in sapphirine. Further splitting of the supergroup based on occupancies other than those specified above is not recommended.

KEYWORDS: nomenclature, aenigmatite, sapphirine, surinamite, chain silicates.

\section{Statement of the problem}

THE sapphirine group and related mineral surinamite are chain silicates that pose nomenclature problems because of the large number of

* E-mail: esgrew@maine.edu sites and potential constituents, including several DOI: $10.1180 /$ minmag.2008.072.4.839 $(\mathrm{Be}, \mathrm{B}, \mathrm{As}, \mathrm{Sb})$ that are rare or absent in related 
chain silicates, together with extensive cation disorder at these sites and the difficulty of deriving Fe valence ratios from electron microprobe analyses; the question of $\mathrm{Ti}$ valence arises in rhönite from the Allende meteorite. We have chosen sapphirine rather than aenigmatite to name the supergroup and larger group therein because sapphirine was the first of these minerals to be discovered, chemically analysed and to have its crystal structure refined. There are 15 independent cationic sites in the centrosymmetric triclinic members of the sapphirine group, 12 in the related monoclinic mineral surinamite and over 20 in members lacking a centre of symmetry (welshite) or having a superstructure (khmaralite). Applying the standard CNMNC guidelines (Nickel and Grice, 1998) to each site individually would result in a plethora of species that would be difficult to distinguish on a routine basis and have little geological or petrological significance. However, failing to take into account cation distribution and order could result in overly broad species definitions. Complicating the situation in the sapphirine group are superstructures, polysomatism and polytypism and changes in symmetry dictated by cation order. Because most sapphirine-group minerals have triclinic symmetry, it took some time to agree on a unit cell, namely the Delaunay cell, which was first proposed by Kelsey and McKie (1964) for aenigmatite and generally adopted afterwards.

To date, criteria applied to distinguish one species from another have been applied ad hoc, making use of site occupancies when available, but relying on stoichiometry in the absence of a crystal structure refinement. In many cases recognizing a new species seemed relatively easy because its composition differed so much from existing species, e.g. Ca vs. Na, presence of $\mathrm{Be}, \mathrm{Sb}, \mathrm{As}$ or B. However, other species proved more difficult, most recently makarochkinite, where detailed crystallographic study was needed to demonstrate ordering of $\mathrm{Ti}$ at a single $M$ site.

Kunzmann (1999) proposed a classification for the sapphirine group that was not reviewed by the CNMMN. His classification included only the Naand Ca-bearing members, aenigmatite and rhönite subgroups, respectively, and was based largely on composition with much less reliance on crystal structure. Consequently, as models to follow in developing a classification, we have sought examples from other mineral groups that have been reviewed recently and approved by the
CNMMN (now CNMNC) or in the process of being considered by the CNMNC. Our approach follows more the direction taken by Hawthorne and Oberti (2006) for amphiboles, for which cation sites were grouped for classification (Hatert and Burke, 2008), rather than treated individually as in the unique-name system adopted by Johnsen et al. (2003) for eudialyte. Our criteria distinguish species in a systematic fashion, that is, we have identified critical individual sites or several sites taken together that can be used as criteria. These criteria include a mixture of chemical and crystallographical properties. Nonetheless, it appears that full application of our nomenclature will require crystal structure refinements.

Our recommended nomenclature has been approved by the Commission on New Minerals, Nomenclature and Classification, International Mineralogical Association.

\section{Definition of the sapphirine and surinamite groups}

Strunz and Nickel (2001) broadened the traditional aenigmatite or aenigmatite-rhönite group (e.g. Kunzmann, 1999) to include the closely related minerals sapphirine and surinamite. Minerals in this group are monoclinic and triclinic chain silicates containing kinked, winged chains of tetrahedra and walls of octahedra. Strunz and Nickel (2001) also suggested that jonesite might be a related mineral, but a subsequent crystal structure refinement of jonesite did not bear this out (Krivovichev and Armbruster, 2004). Gaines et al. (1997) suggested that magbasite, $\mathrm{KBa}\left(\mathrm{Mg}, \mathrm{Fe}^{2+}\right)_{6}(\mathrm{Al}, \mathrm{Sc}) \mathrm{Si}_{6} \mathrm{O}_{20} \mathrm{~F}_{2}$, which was described by Semenov et al. (1965), could be in the sapphirine group, but there is no evidence for such a relationship. Only a powder diffraction pattern was reported in the original description (single crystal data could not be obtained) and it differs substantially from that of aenigmatite reported by Kelsey and McKie (1964). The chemical composition recalculated on a 28 cation basis (cf. 15 cations in the given formula) gave $4.9 \mathrm{~F}, 1.6 \mathrm{Ba}$ and $1.8 \mathrm{~K}$, none of which are reported in comparable quantities, if at all, in sapphirine-group minerals and compounds (cf. $4 \mathrm{OH}$ in a synthetic isostructural with aenigmatite, Yang and Konzett, 2000).

We agree with Strunz and Nickel (2001) that sapphirine and aenigmatite should be included in the same group, but we disagree that surinamite also belongs there. Instead, classification of 
sapphirine and related minerals are better understood in terms of a polysomatic series involving one clinopyroxene-like module (or a close-packed isotype of clinopyroxene like $\mathrm{CoGeO}_{3}$, which was refined by Peacor, 1968) and one spinel module (Dornberger-Schiff and Merlino, 1974; Christy and Putnis, 1988; Barbier and Hyde, 1988; Bonaccorsi et al., 1990, Arakcheeva and Ivanov, 1993; Merlino and Pasero, 1997; Gasparik et al., 1999; Zvyagin and Merlino, 2003), which more specifically defines the relationship of surinamite to sapphirine and aenigmatite and leaves open the possibility of other polysomes being included in the future. Thus, we are introducing the concept of a sapphirine supergroup that would encompass all the polysomes. The sapphirine group includes only the polysome consisting of one clinopyroxene or pyroxene-like module and one spinel module. The sapphirine group can be divided into three subgroups on the basis of the dominant cations in the polyhedra outside the octahedral walls; a fourth subgroup needs more study (Table 1). In the aenigmatite and rhönite subgroups, the octahedral walls are cross-linked into continuous sheets by 7-8 coordinated polyhedra containing $\mathrm{Na}$ and $\mathrm{Ca}$, respectively. The corresponding sites in the sapphirine subgroup are 6 coordinated, and the octahedral walls are not cross-linked.

The surinamite group would include the polysome consisting of two pyroxene modules and one spinel module. To date, there is only one known natural compound in this group occurring as an independent phase, surinamite itself, and thus designating a surinamite group anticipates the recognition of more species. The surinamite structure differs from those of the sapphirine group in the proportion of wing to chain tetrahedra: $20 \%$ vs. $33 \%$, and in the position of the wings, which are all on one side of the chains in surinamite, but on both sides in the sapphirine group.

\section{Historical synopsis}

\section{Sapphirine, khmaralite}

Sapphirine is the first sapphirine-group mineral to be discovered, chemically analyzed and to have its crystal structure refined. Giesecke found sapphirine in 1809 at Fiskenæsset, West Greenland, and called it 'blauer Diamantspath (saphirine)' in his catalogues (Bøggild, 1953). The first description of Giesecke's mineral, including a density measurement and full chemical analysis, was reported by Stromeyer (1819, 1821), who retained Giesecke's name 'saphirine', later changed to the present spelling with double p. Over a century of study (e.g. Ussing, 1889; Lorenzen, 1893), including singlecrystal X-ray diffraction (XRD) (Goßner and Mußgnug, 1928; Kuzel, 1961; McKie, 1963; Fleet, 1967), gave a range of compositions from $\mathrm{Mg}_{2} \mathrm{Al}_{4} \mathrm{Si}_{2} \mathrm{O}_{10}$ to somewhat richer in $\mathrm{Al}$ than $\mathrm{Mg}_{7} \mathrm{Al}_{18} \mathrm{Si}_{3} \mathrm{O}_{40}$, the formula given in Table 1; these formulae are related by the Tschermak's substitution $\mathrm{Mg}+\mathrm{Si} \rightleftharpoons 2 \mathrm{Al}$ (e.g. Vogt, 1947). However, a fuller understanding of its crystal chemistry was not possible until Moore's (1968; 1969) successful refinement of the structure of monoclinic sapphirine from Fiskenæsset. Merlino $(1970,1972)$ recognized that the crystal structures of sapphirine, aenigmatite, krinovite and rhönite, were all closely related, and thereby provided the conceptual basis for the sapphirine group. Merlino (1980) refined the crystal of the triclinic polytype, further linking the sapphirine subgroup with the other two subgroups. In addition to the $1 A$ and $2 M$ polytypes, which dominate natural sapphirine (e.g. Christy, 1989), Merlino and Pasero (1987) and Christy and Putnis (1988) found $3 A, 4 M$ and $5 A$ polytypes as domains ranging from less than $100 \AA$ to several thousand ångströms thick.

Grew (1981) described a 'beryllian sapphirine' containing $1.4 \mathrm{Be}$ per formula unit of 28 cations from Zircon Point, a small exposure in Khmara Bay, Enderby Land, East Antarctica. Christy (1988), using transmission electron microscopy (TEM), recognized this mineral as having a superstructure with doubled $a$ axis $\left(P 2_{1} / c\right.$ setting). Refinement of the structure using XRD became possible only when the very weak superstructure reflections could be measured, which Barbier et al. (1999) succeeded in doing with a Siemens diffractometer and a SMART area detector, and thus were able to demonstrate ordering of Be at alternating $T 2$ and $T 3$ sites in doubled tetrahedral chains. The refinement served to distinguish khmaralite from sapphirine- $2 M$ both by the presence of the $2 \times a$ superstructure and the predominance of $\mathrm{Be}$ at one tetrahedral site. The name 'beryllosapphirine' was not applied by Barbier et al. (1999) because they reasoned that a mineral of this name should have the same space group as sapphirine- $2 M$ and similar cell parameters, and thus they named the mineral for the locality. Grew et al. (2000) reported a weak $2 \times a$ superstructure in a sample from a second locality in Khmara Bay that 
E. S. GREW ET AL.

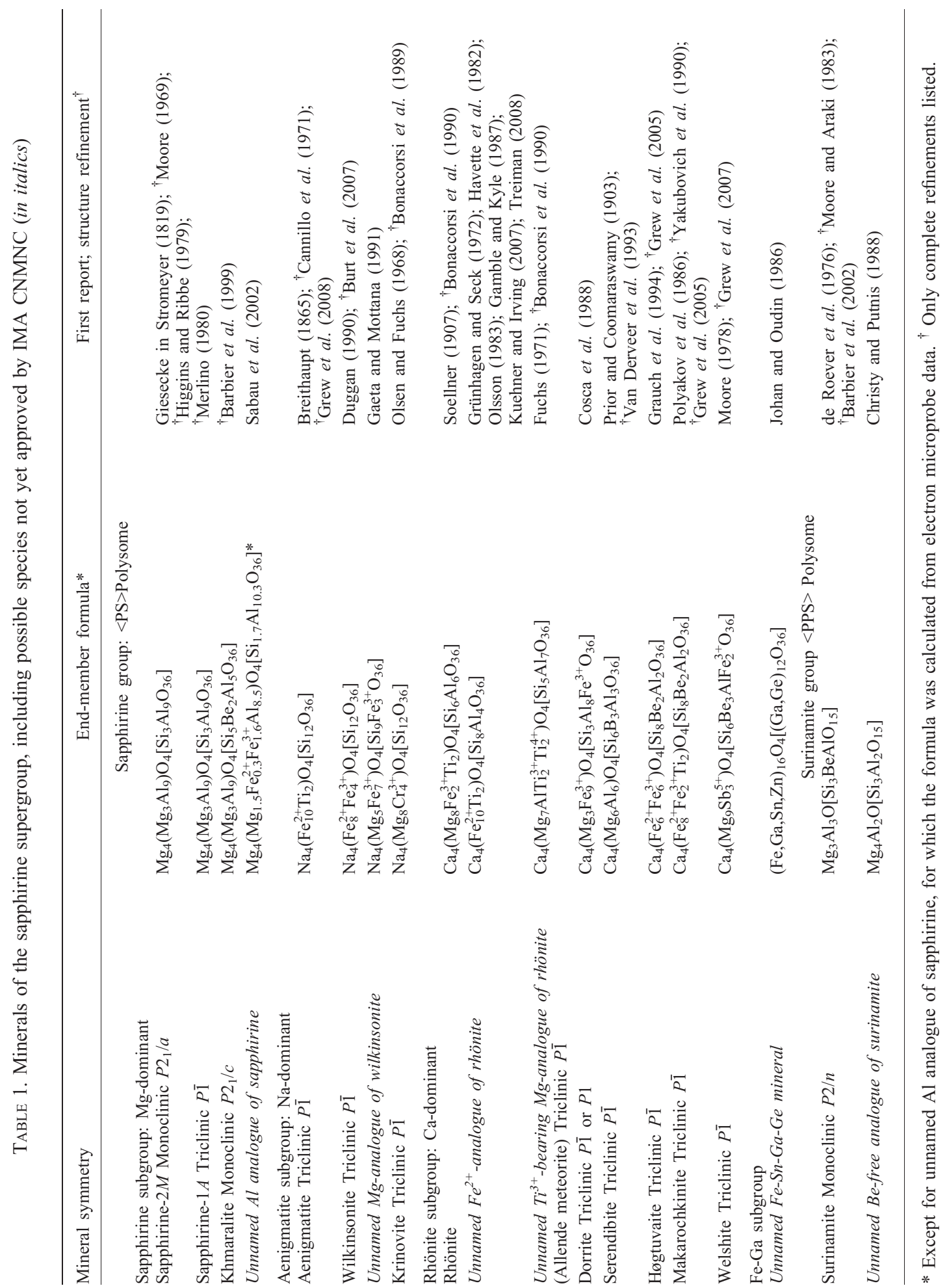


contained $0.87-1.05$ Be per 28 cations, i.e. the appearance of the superstructure defining khmaralite coincides with Be occupancy approaching $50 \%$ at the $T 2$ and $T 3$ sites considered together.

\section{Aenigmatite, wilkinsonite, krinovite}

Breithaupt (1865) simultaneously introduced two new monoclinic minerals 'kölbingite' and 'ainigmatite', which he discovered in samples of peralkaline plutonic rocks from the Ilímaussaq complex, Kangerdluarssuk, Greenland (Bøggild, 1953). He named the first for his late friend Kölbing and the second from the Greek ainigma for its enigmatic nature by comparison with 'kölbingite'; indeed, aenigmatite has proven to be a most appropriate name. Breithaupt (1865) reported both minerals as being greenish to velvet-black in colour and having the identical prismatic habit, but differing in streak, density and hardness, and suggested that 'ainigmatite' was pseudomorphous after 'kölbingite'. No quantitative analysis was given for either mineral; preliminary analyses gave $\mathrm{Ca}, \mathrm{Fe}$ and $\mathrm{Si}$, with Fe largely ferrous in 'kölbingite' and ferric in aenigmatite. Lorenzen (1882) doubted the pseudomorphous nature of aenigmatite because the aenigmatite crystals available to him were all very fresh and unaltered (he did not have any crystals of 'kölbingite' to compare). Forsberg (in Brögger, 1887, 1890) was the first to obtain a complete analysis of the major constituents in aenigmatite including $\mathrm{Ti}$, which he found was major. Brögger $(1887,1890)$ also gave some optical properties of aenigmatite, and thus was able to finally confirm its validity as a mineral species. Brögger $(1887,1890)$ also suggested that 'kölbingite' was an intergrowth of arfvedsonite and aenigmatite by noting that the density and streak color of 'kölbingite' are intermediate between those of arfvedsonite and aenigmatite. Ussing (1898) was able to examine a 'kölbingite' crystal from the material studied by Breithaupt, and showed that similar specimens in the Mineralogical Museum in Copenhagen consisted of aenigmatite coated with aegirine, leading him to conclude that Breithaupt's (1865) 'kölbingite' was but a mixture of aenigmatite and aegirine.

Foerstner (1881) described the new triclinic mineral 'cossyrite' in volcanic rocks of the island Pantelleria, southern Italy (Cossyra in ancient times), and reported a chemical analysis, but not including Ti. Groth (1883) noted that 'cossyrite' and aenigmatite could be related, which Brögger
$(1887,1890)$ confirmed by detailed comparison of the chemical composition and crystal morphology. Thus, Brögger $(1887,1890)$ gave aenigmatite priority, and considered the name 'cossyrite' to be only a synonym. Discredition of 'cossyrite' was complete when powder X-ray data by A.S. Anisimova confirmed its identity as aenigmatite (Fleischer, 1964).

Brögger $(1887,1890)$ suggested that aenigmatite could be a triclinic member of the amphibole group despite the nearly $10^{\circ}$ difference in the angle between the cleavages $\left(66^{\circ}\right.$ vs. $56^{\circ}$ for arfvedsonite) and a significant difference in axial ratio, both of which he attributed to substitution of Si by Ti. In contrast, Soellner (1909) placed 'cossyrite' and aenigmatite in a separate group that was on a par with pyroxenes and amphiboles. X-ray studies by Goßner and Mußgnug (1929) showed that aenigmatite is not related to amphibole, and this conclusion was confirmed by morphological crystallography (Palache, 1933) and chemical analyses (Fleischer, 1936). On the basis of literature data and new analyses, Kelsey and McKie (1964) settled on the now accepted crystallographic orientation (Delaunay cell), unit cell content and formula (Table 1). Thompson and Chisholm (1969) synthesized aenigmatite with the composition deduced by Kelsey and McKie (1964).

Three groups simultaneously solved the crystal structure of aenigmatite: Merlino (1970); Cannillo and Mazzi; and Fang, Robinson and Ohya; the latter two groups reported their results in a joint publication (Cannillo et al. 1971). Choi (1983) and Choi and Burns (1983) reported Mössbauer spectroscopic evidence for the presence of $\mathrm{Fe}^{3+}$ on tetrahedral sites. A new refinement and Mössbauer spectrum (Grew et al., 2008) confirm the essential features reported earlier, but bring greater precision to cation ordering in aenigmatite.

Hodges and Barker (1973) reported extensive solid solution by the substitution of $\mathrm{Fe}^{2+}+\mathrm{Ti}$ by $2 \mathrm{Fe}^{3+}$ between 'ideal aenigmatite' and the titanium-free aenigmatite which had been synthesized by Ernst (1962) in the Na-Fe-Si-H-O system. Duggan (1990) described the latter as the new mineral wilkinsonite from peralkaline, silica-undersaturated trachyte of Warrumbungle volcano, New South Wales, Australia, which he named to honor J.F.G. Wilkinson for his work on volcanic rocks where the mineral was found. In demonstrating the solid solution between the two minerals, Hodges and Barker (1973) and Duggan (1990) did not measure $\mathrm{Fe}^{3+}$ directly, but 
calculated it from stoichiometry. The structure of wilkinsonite is the most recent of sapphirinegroup minerals to be refined (Burt et al., 2007).

Olsen and Fuchs (1968) described krinovite as a monoclinic $\mathrm{Na}-\mathrm{Mg}-\mathrm{Cr}$ silicate from three octahedrite meteorites. The mineral was named to honor E.L. Krinov for his work on meteorites. Its relationship to aenigmatite was not demonstrated until Merlino (1972) carried out a crystallographic study establishing its triclinic symmetry, and selected a triclinic cell to conform to the Delaunay cell used by Kelsey and McKie (1964) for aenigmatite. Bonaccorsi et al. (1989) solved the structure.

\section{Rhönite, dorrite, høgtuvaite, makarochkinite, welshite, serendibite}

Soellner (1907) first recognized rhönite, which he named for the Rhön Mountains of central Germany, as a distinct triclinic mineral and realized it was isomorphic with aenigmatite and 'cossyrite'. Soellner found rhönite in alkaline basaltic rocks not only in the Rhön Mountains, but also at several localities elsewhere in Germany and in Bohemia plus one in Sweden. Walenta (1969) confirmed triclinic symmetry using singlecrystal methods, and Merlino (1972) fixed the triclinic cell to conform to the Delaunay cell used by Kelsey and McKie (1964) for aenigmatite. Bonaccorsi et al. (1990) first refined the structure. Although rhönite had a simpler history than aenigmatite, settling on a formula was complicated by the greater compositional variation in rhönite. Fleischer (1936) suggested that aenigmatite and rhönite were related by the substitution $\mathrm{Ca}$ $+\mathrm{Al} \rightleftharpoons \mathrm{Na}+\mathrm{Si}$ by analogy with feldspar, but Cameron et al. (1970) found that other substitutions were involved and noted the substantial compositional gap between the two minerals.

Fuchs (1971, 1978), Mason and Taylor (1982) and Simon et al. (1999) described rhönite containing about twice as much $\mathrm{Ti}$ as in other rhönite from calcium and aluminum rich inclusions in the Allende meteorite. Stoichiometry requires that a substantial portion of the $\mathrm{Ti}$ be trivalent. The presence of $\mathrm{Ti}^{3+}$ in a synthetic analogue 'baykovite' is indicated by its distinctive absorption (Rudneva and Malysheva, 1960). Structures of Allende rhönite and 'baykovite' were refined by Bonaccorsi et al. (1990) and Arakcheeva (1995), respectively.

Cosca et al. (1988) described a Ti-poor, $\mathrm{Fe}^{3+}$ rich analogue of rhönite from pyrometamorphic melt-rock (paralava) in the Powder River Basin, Wyoming, as the new mineral dorrite in honor of John A. Dorr, Jr., a professor at the University of Michigan. Negligible Ti content and dominance of $\mathrm{Fe}^{3+}$ at octahedral sites were cited to distinguish dorrite from rhönite. On the basis of single-crystal data and absent a structure refinement, Cosca et al. (1988) inferred that dorrite was isostructural with aenigmatite and rhönite, and thus calculated dorrite composition assuming aenigmatite-group stoichiometry. Calculated $\mathrm{Fe}^{3+}$ occupies $66-73 \%$ of the octahedral sites in type dorrite, and $\mathrm{Al}+\mathrm{Fe}^{3+}$ exceeds $\mathrm{Si}$ at the tetrahedral sites. Refinements of SFCA (silicoferrite of $\mathrm{Ca}$ and $\mathrm{Al}$ ) and SFCAM (plus $\mathrm{Mg}$ ) in the matrix of sinter ore show that these ferrites are isostructural with rhönite and compositionally closest to dorrite (Mumme, 1988, 2003; Hamilton et al., 1989; Mumme et al., 1998; Sugiyama et al., 2005).

Makarochkinite is named for Boris A. Makarochkin, Russian chemist and mineralogist, who studied the rare minerals from the Il'men Mountains, southern Urals, near Miass, Russia where the mineral was found in a pegmatite (Polyakov et al., 1986). These authors reported that a proposal for makarochkinite was submitted to the CNMMN, but apparently there is no record of a vote; Shcherbakova et al. (2004) were skeptical that the materials ever reached the Commission. Høgtuvaite was first introduced as a new species with an end-member formula $\mathrm{Ca}_{4}\left(\mathrm{Fe}_{10}^{2+} \mathrm{Ti}_{2}\right) \mathrm{O}_{4}\left[\mathrm{Si}_{10} \mathrm{Be}_{2}\right] \mathrm{O}_{36}$ from Be-rich orthogneiss at Høgtuva, a window of Proterozoic rocks in the Caledonides, Nordland County, Norway (Grauch et al. 1994; Burt 1994). The mineral was distinguished from rhönite because it contained sufficient $\mathrm{Be}$ to fill one tetrahedral site. In the absence of a structure refinement, Burt (1994) applied the vector method to define høgtuvaite. Grauch et al. (1994) equated makarochkinite with høgtuvaite, but learned too late of the crystal structure refinement of makarochkinite, which gave $50 \%$ Be occupancy at two sites (Yakubovich et al., 1990), to include it in their discussion. Makarochkinite remained a synonym for høgtuvaite until Grew et al. (2005) obtained CNMMN approval for its being distinct from høgtuvaite on the basis of new structural refinements showing dominance of $\mathrm{Ti}$ at $M 7$, whereas distinction from rhönite remained based on stoichiometry, i.e. sufficient Be to occupy the equivalent of one tetrahedral site. The formulae proposed by Grew et al. (2005) for høgtuvaite and 
makarochkinite take into account the significant amounts of $\mathrm{Al}$ and $\mathrm{Fe}^{3+}$ present in both minerals (Table 1).

Ever since its first mention as an unnamed monoclinic mineral, $\mathrm{Ca}_{2}(\mathrm{Mg}, \mathrm{Fe})_{4} \mathrm{SbSi}_{4} \mathrm{O}_{12}(\mathrm{OH})_{8}$, from the Fe-Mn skarn deposit of Långban, Sweden (Moore, 1967), welshite has been one of the most intractable of the sapphirine group. After announcing the name (for Wilfred R. Welsh, teacher and amateur mineralogist) in 1970 (Moore, 1970) and obtaining approval by the CNMMN in 1973, Moore (1978) finally published his description of welshite as a sapphirine-group mineral with the formula $\mathrm{Ca}_{4} \mathrm{Mg}_{8} \mathrm{Fe}_{2}^{3+} \mathrm{Sb}_{2}^{5+} \mathrm{O}_{4}\left[\mathrm{Si}_{8} \mathrm{Be}_{4} \mathrm{O}_{36}\right]$. Taking advantage of Mössbauer spectroscopy and ion microprobe analyses of Be, Grew et al. (2001) had a firmer basis for determining a formula and locating $\mathrm{Fe}$ in the structure. However, attempts to refine the crystal structure were foiled by polysynthetic twinning and an eclectic composition until J. Barbier successfully overcame these difficulties to solve one welshite structure, showing this mineral to be the only noncentrosymmetric sapphirine-group mineral and allowing for the development of a satisfactory end-member formula (Grew et al., 2007).

Prior and Coomaraswamy (1903) first described serendibite from a calc-silicate skarn in Sri Lanka and named it for Serendib, the old Arabic designation for this island. Ye. N. Belova (in Pertsev and Nikitina, 1959) and Süsse (1968) carried out single-crystal work on serendibite and determined that it is triclinic, but Machin and Süsse (1974) were the first to recognize its relationship to the sapphirine group and adopted the Delaunay cell used by Kelsey and McKie (1964) for aenigmatite. Buerger and Venkatakrishnan (1974) refined the structure, but only to $\mathrm{R}=7.1 \%$. They reported $\mathrm{B} \rightleftharpoons \mathrm{Al}$ and $\mathrm{Mg} \rightleftharpoons \mathrm{Ca}$ substitutions, anomalous features that prompted Van Derveer et al. (1993) to refine the structures of three serendibite samples differing in $\mathrm{Fe}$ content to weighted $\mathrm{R}=$ 2.8-3.3 wt.\%, and thereby established $\mathrm{Si} \rightleftharpoons \mathrm{B}$ substitution at the $T 1$ and $T 4$ sites and $\mathrm{Ca} \rightleftharpoons \mathrm{Na}$ substitution at the $M 8$ and $M 9$ sites.

\section{Surinamite}

Surinamite was first described as sapphirine in a metamorphic rock from the Bakhuis Mountains, Surinam (de Roever, 1973), but chemical analyses and X-ray study showed it to be a new ferromagnesian aluminosilicate (de Roever et al., 1976; Moore, 1976). De Roever et al., (1981) and Grew (1981) discovered independently that $\mathrm{Be}$ is an essential constituent; the formula proposed by de Roever et al., (1981) with 1 Be per 11 cations was confirmed by crystal structure refinements (Moore and Araki, 1983; Barbier et al., 2002). Surinamite being similar in appearance to sapphirine is no accident. As mentioned above, both structure types belong to a polysomatic series consisting of pyroxene and spinel modules. The sapphirine and surinamite structure types are intergrown on a submicroscopic scale in natural ferromagnesian aluminosilicate (Christy and Putnis, 1988) and synthetic Mg-Ga germanate (Barbier, 1996).

\section{Crystal structures}

\section{Sapphirine-IA}

In the five polytypes of sapphirine that have been recognized (Merlino and Pasero, 1987; Christy and Putnis, 1988), order-disorder features are present (Merlino and Zvyagin, 1998), but only the centrosymmetric triclinic sapphirine-1A (Fig. 1) is topologically identical with minerals in the aenigmatite and rhönite subgroups (Table 2). There are six tetrahedral sites of equal rank in chains parallel to the $a$ axis. Tetrahedral linkage is 1 for the two tetrahedral wings (T5, T6), 3 for the two chain tetrahedra $(T 2, T 3)$ linked to the wings and 2 for the other chain tetrahedra $(T 1, T 4)$. There are seven octahedral sites. Five ( $M 1-M 4$, M7) of these constitute the walls, which lie in the (011) plane and extend parallel to the $a$ axis, and two are outside the wall $(M 8, M 9) . M 7$ is distinctive in that it shares the most edges (7) with adjacent polyhedra. The main difference between sapphirine- $1 A$ and minerals in the aenigmatite and rhönite subgroups is that the $M 5$ and $M 6$ sites (corresponding to $M 8$ and $M 9$ in the other subgroups) in sapphirine- $1 A$ are 6-coordinated. These octahedra do not cross-link the octahedral walls, but can be considered part of these walls (Moore, 1969). The oxygen anions are cubic close-packed in sapphirine, whereas $\mathrm{Ca}$ and $\mathrm{Na}$ disrupt close packing in the other subgroups.

In general, cation ordering in the sapphirine group is primarily driven by charge ordering and should be similar given the similar topologies of the structures. However, the degree of ordering will depend on the chemical composition of a particular phase through the charges of the cations occupying the various $M$ and $T$ sites. In 


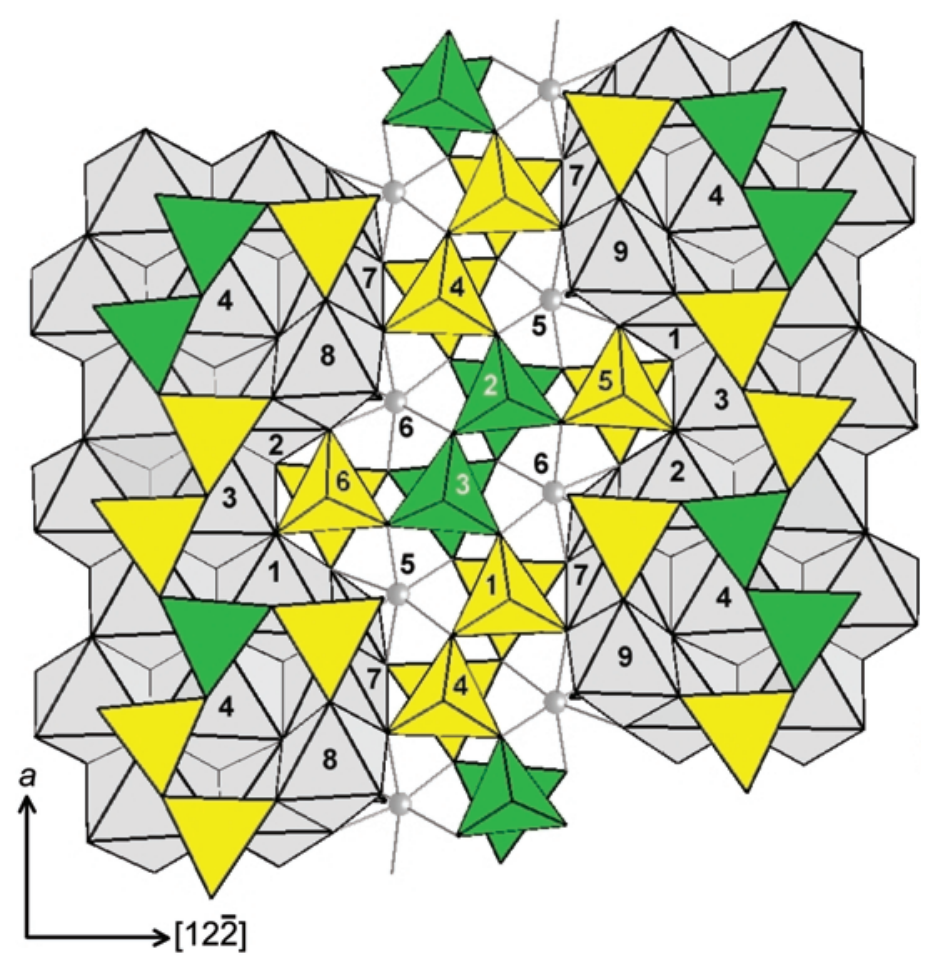

FIG. 1. Crystal structure of sapphirine-1A. Numbering of sites corresponds to column 1 of Table 2. Oriented to facilitate comparison of site numbering with that in the makarochkinite structure shown in Fig. 3. Green tetrahedra: $\mathrm{Si}=\mathrm{Al}$ or $\mathrm{Si}>\mathrm{Al}$; yellow tetrahedra: $\mathrm{Al}$ or $\mathrm{Al}>\mathrm{Si}$.

sapphirine- $1 A$ there is a moderately high degree of cation order at both the $M$ and the $T$ sites.

\section{Sapphirine-2M and khmaralite}

The two monoclinic minerals in the sapphirine subgroup are not topologically identical to sapphirine-1A, but differ in the number of $M$ sites: the two non-wall $M$ sites in the triclinic structure are equivalent in sapphirine-2M. Khmaralite differs from sapphirine- $2 M$ in having a supercell due to doubling along the $a$ axis; it has $12 T$ sites and $16 M$ sites (Fig. 2; Table 3). This response to $\mathrm{Be}$ incorporation differs from that in the rhönite subgroup, and allows a maximum of only 2 Be per 28 cations.

\section{Aenigmatite, wilkinsonite, krinovite}

The compositions of the aenigmatite subgroup minerals whose structures have been refined (Tables 2,3 ) are relatively highly ordered, with all the $T$ sites occupied by $\mathrm{Si}$; $M 7$ occupied by the more highly charged cation, e.g. Ti in aenigmatite and $\mathrm{Cr}$ in krinovite, and $M 3-M 6$ sites by divalent cations. $\mathrm{Cr}$ also occupies the $M 1$ and $M 2$ sites in krinovite. The new refinement of aenigmatite (Grew et al., 2008) gives greater cation order at $M 1-M 7$ sites than earlier reported (Cannillo et al., 1971), viz. $100 \%$ (vs. 59\%) of $\mathrm{Ti}$ at $M 7$ and subordinate $\mathrm{Mg}$ substitutes for $\mathrm{Fe}$ only at $M 3-M 6 . \mathrm{Fe}^{3+}$ is dominant at the $M 1, M 2$ and $M 7$ sites in wilkinsonite (Burt et al., 2007).

Rhönite, rhönite (Allende), høgtuvaite, makarochkinite, welshite

Compositions of the $M 1-M 7$ and $T$ sites are more complex and cation disorder greater in the five rhönite subgroup minerals for which structure refinements are known (Fig. 3; Table 2). M8 and $M 9$ are dominantly $\mathrm{Ca}$ and the distinction between the seven shorter bonds and one longer bond is commonly more marked. Be and B are concentrated on the most polymerized $T$ sites $(T 1, T 4)$. Ti is ordered at $M 7$ in høgtuvaite, makarochkinite 
TABLE 2. Simplified occupancies in minerals of the aenigmatite subgroup, rhönite subgroup (except dorrite) and sapphirine- $1 A$ based on crystal structure refinements.

\begin{tabular}{|c|c|c|c|c|c|c|c|c|c|c|c|}
\hline S.G. & $\begin{array}{c}\text { Spr-1A } \\
P \overline{1}\end{array}$ & & $\begin{array}{l}\text { Aen } \\
P \overline{1}\end{array}$ & $\begin{array}{l}\text { Wlk } \\
P \overline{1}\end{array}$ & $\begin{array}{l}\text { Krin } \\
\mathrm{P} \overline{1}\end{array}$ & $\begin{array}{l}\mathrm{Rhö} \\
P \overline{1}\end{array}$ & $\begin{array}{c}\text { Rhö-All } \\
P \overline{1}\end{array}$ & $\begin{array}{l}\mathrm{H} ø \mathrm{~g} \\
P \overline{1}\end{array}$ & $\begin{array}{c}\mathrm{Mkr} \\
P \overline{1}\end{array}$ & $\begin{array}{c}\text { Welshite* } \\
\quad P 1\end{array}$ & $\begin{array}{l}\text { Srd } \\
P \overline{1}\end{array}$ \\
\hline$T 3 * *$ & $\mathrm{Si}=\mathrm{Al}$ & $T 1^{* *}$ & $\mathrm{Si}$ & $\mathrm{Si}$ & $\mathrm{Si}$ & $\mathrm{Si}=\mathrm{Al}$ & $\mathrm{Si}=\mathrm{Al}$ & $\mathrm{Si}=\mathrm{Be}$ & $\mathrm{Si}=\mathrm{Be}$ & $\mathrm{Si} / \mathrm{Be}$ & $\mathrm{B} \geqslant \mathrm{Si}$ \\
\hline$T 4$ & $\mathrm{Al}>\mathrm{Si}$ & $T 2$ & $\mathrm{Si}$ & $\mathrm{Si}$ & $\mathrm{Si}$ & $\mathrm{Si}=\mathrm{Al}$ & $\mathrm{Si}=\mathrm{Al}$ & $\mathrm{Si}$ & $\mathrm{Si}$ & $\mathrm{Si} / \mathrm{Be}$ & $\mathrm{Si}$ \\
\hline$T 1$ & $\mathrm{Al}$ & $T 3$ & $\mathrm{Si}$ & $\mathrm{Si}$ & $\mathrm{Si}$ & $\mathrm{Si}=\mathrm{Al}$ & $\mathrm{Si}=\mathrm{Al}$ & $\mathrm{Si}>\mathrm{Al}$ & $\mathrm{Si}=\mathrm{Al}$ & $\mathrm{Be}=\mathrm{Al} / \mathrm{Si}$ & $\mathrm{Al}$ \\
\hline$T 2 * *$ & $\mathrm{Si}>\mathrm{Al}$ & $T 4 * *$ & $\mathrm{Si}$ & $\mathrm{Si}$ & $\mathrm{Si}$ & $\mathrm{Si}=\mathrm{Al}$ & $\mathrm{Si}=\mathrm{Al}$ & $\mathrm{Si}=\mathrm{Be}$ & $\mathrm{Si}=\mathrm{Be}$ & $\mathrm{Be} / \mathrm{Si}$ & B \\
\hline$T 6$ & $\mathrm{Al}>\mathrm{Si}$ & $T 5$ & $\mathrm{Si}$ & $\mathrm{Si}$ & $\mathrm{Si}$ & $\mathrm{Si}=\mathrm{Al}$ & $\mathrm{Al}$ & $\mathrm{Si}$ & $\mathrm{Si}$ & $\mathrm{Al}=\mathrm{Fe} / \mathrm{Si}$ & $\mathrm{Si}$ \\
\hline$T 5$ & $\mathrm{Al}$ & $T 6$ & $\mathrm{Si}$ & $\mathrm{Si}$ & $\mathrm{Si}$ & $\mathrm{Si}=\mathrm{Al}$ & $\mathrm{Al}$ & $\mathrm{Si}$ & $\mathrm{Si}$ & $\mathrm{Si} / \mathrm{Al}=\mathrm{Fe}$ & $\mathrm{Si}$ \\
\hline$M 8^{* *}$ & $\mathrm{Al}$ & $M 1^{* *}$ & $\mathrm{Fe}$ & $\mathrm{Fe}$ & $\mathrm{Cr}$ & $\mathrm{Mg}$ & $\mathrm{Mg}=\mathrm{Ti}$ & $\mathrm{Fe}$ & $\mathrm{Fe}$ & $\mathrm{Mg}$ & $\mathrm{Al}$ \\
\hline$M 9^{* *}$ & $\mathrm{Al}$ & $M 2^{* *}$ & $\mathrm{Fe}$ & $\mathrm{Fe}$ & $\mathrm{Cr}$ & $\mathrm{Mg}$ & $\mathrm{Mg}=\mathrm{Ti}$ & $\mathrm{Fe}$ & $\mathrm{Fe}$ & $\mathrm{Mg}$ & $\mathrm{Al}$ \\
\hline$M 1$ & $\mathrm{Al}$ & M3 & $\mathrm{Fe}$ & $\mathrm{Fe}$ & $\mathrm{Mg}$ & $\mathrm{Mg}$ & $\mathrm{Mg}=\mathrm{Ti}$ & $\mathrm{Fe}$ & $\mathrm{Fe}$ & $\mathrm{Mg} / \mathrm{Sb}$ & $\mathrm{Al}$ or $\mathrm{Mg}$ \\
\hline$M 2$ & $\mathrm{Al}$ & M4 & $\mathrm{Fe}$ & $\mathrm{Fe}$ & $\mathrm{Mg}$ & $\mathrm{Mg}$ & $\mathrm{Mg}=\mathrm{Ti}$ & $\mathrm{Fe}$ & $\mathrm{Fe}$ & $\mathrm{Mg} / \mathrm{Sb}$ & $\mathrm{Al}$ \\
\hline$M 4$ & $\mathrm{Mg}$ & M5 & $\mathrm{Fe}$ & $\mathrm{Fe}$ & $\mathrm{Mg}$ & $\mathrm{Mg}$ & $\mathrm{Mg}$ & $\mathrm{Fe}$ & $\mathrm{Fe}$ & $\mathrm{Mg} / \mathrm{Mg}$ & $\mathrm{Mg}$ \\
\hline$M 3$ & $\mathrm{Mg}$ & M6 & $\mathrm{Fe}$ & $\mathrm{Fe}$ & $\mathrm{Mg}$ & $\mathrm{Mg}$ & $\mathrm{Mg}$ & $\mathrm{Fe}$ & $\mathrm{Fe}$ & $\mathrm{Mg} / \mathrm{Mg}$ & $\mathrm{Mg}$ \\
\hline$M 7$ & $\mathrm{Al}$ & $M 7$ & $\mathrm{Ti}$ & $\mathrm{Fe}$ & $\mathrm{Cr}$ & $\mathrm{Ti}$ & $\mathrm{Mg}=\mathrm{Ti}$ & $\mathrm{Fe}$ & $\mathrm{Ti}$ & $\mathrm{Sb} / \mathrm{Mg}$ & Al \\
\hline M5 & $\mathrm{Mg}$ & M8 & $\mathrm{Na}$ & $\mathrm{Na}$ & $\mathrm{Na}$ & $\mathrm{Ca}$ & $\mathrm{Ca}$ & $\mathrm{Ca}$ & $\mathrm{Ca}$ & $\mathrm{Ca} / \mathrm{Ca}$ & $\mathrm{Ca}$ \\
\hline M6 & $\mathrm{Mg}$ & M9 & $\mathrm{Na}$ & $\mathrm{Na}$ & $\mathrm{Na}$ & $\mathrm{Ca}$ & $\mathrm{Ca}$ & $\mathrm{Ca}$ & $\mathrm{Ca}$ & $\mathrm{Ca} / \mathrm{Ca}$ & $\mathrm{Ca}$ \\
\hline
\end{tabular}

Sources given in Table 1. Dorrite is not included because the structure has not been refined. S.G. - space group. The site labelling (first column) applies only to sapphirine-1A (the third column gives the correspondence for the other minerals). Equal sign $(=)$ indicates approximately equal occupancy by the given constituents.

* For welshite, all sites are split except for non-wall octahedra $M 1$ and $M 2$, so occupancies for both sites are given, separated by a forward slash, with the $A$-labelled site second.

** Indicates the most polymerized $T$ sites and non-wall octahedral sites.

Abbreviations: Spr-1A - sapphirine-1A, Aen - aenigmatite, Wlk - wilkinsonite, Krin - krinovite, Rhö - rhönite, RhöAll - rhönite from the Allende meteorite, Høg - høgtuvaite, Mkr - makarochkinite, Srd - serendibite.

and rhönite, whereas $\mathrm{Mg}, \mathrm{Fe}^{2+}$ and $\mathrm{Fe}^{3+}$ are disordered over the $M 1-M 6$ sites. The Allende rhönite differs in that $\mathrm{Ti}$ (including $\mathrm{Ti}^{3+}$ as well as $\left.\mathrm{Ti}^{4+}\right)$ and $\mathrm{Mg}$ are disordered over the $M 1-M 4$ and $M 7$ sites, leaving $M 5$ and $M 6$ dominated by $\mathrm{Mg}$.

In contrast to other minerals in the aenigmatite and rhönite subgroups, rhönite has at least two polytypes. Bonaccorsi et al. (1990) gave HRTEM evidence for an 8-layer polytype of rhönite (rhönite- $8 A$ ) that is $200 \AA$ wide in a crystal from Scharnhausen, Germany.

Welshite is unique among minerals in the sapphirine group in being non-centrosymmetric with $12 T$ sites and $16 M$ sites, the increase resulting from the loss of the symmetry center (Fig. 4). The first successful crystal structure refinement also resulted in a new end-member formula (Table 1), which differs significantly from the one proposed by Moore (1978) and given in standard references, $\mathrm{Ca}_{4}\left(\mathrm{Mg}_{8} \mathrm{Sb}_{2} \mathrm{Fe}_{2}^{3+}\right) \mathrm{O}_{4}$ $\left[\mathrm{Si}_{8} \mathrm{Be}_{4} \mathrm{O}_{36}\right]$ (e.g. Strunz and Nickel, 2001). Be is not restricted to the most polymerized $T$ sites ( $T 1$, $T 1 \mathrm{~A}, T 4, T 4 \mathrm{~A})$ sites nor is $\mathrm{Sb}$ restricted to the $M$ sites with the most shared edges (M7, M7A). Nonetheless, there is considerable cation order, which allows for incorporation of more Be than in other minerals of the group, up to $3.46 v s$. the maximum of $2.1 \mathrm{Be}$ per 28 cations (høgtuvaite) and still avoids $\mathrm{Be}-\mathrm{O}-\mathrm{Be}$ bridges.

\section{Surinamite}

Surinamite (Fig. 5) is highly ordered compared to sapphirine and khmaralite. As in sapphirine, the oxygen anions are cubic close-packed. Only one polytype $(1 M)$ has been reported for natural surinamite, which has space group $P 2 / n$, although a different polytype $(2 M)$ with space group $C 2 / c$ is realized in a synthetic Ga-Ge analogue of surinamite (Barbier, 1996, 1998).

\section{Compositional variations}

\section{Sapphirine-IA and -2M, khmaralite}

The principal compositional variations in Be- and B-free sapphirine include the homovalent $\mathrm{Fe} \rightleftharpoons$ 


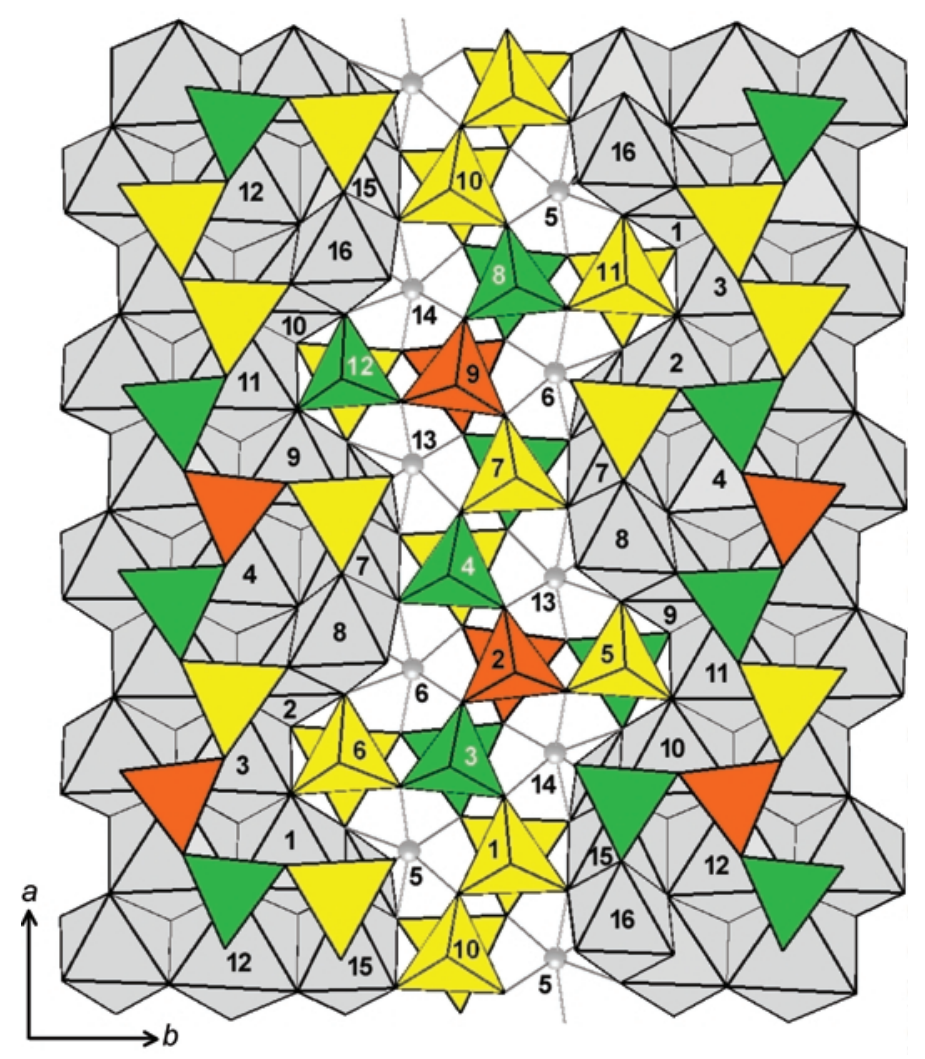

FIG. 2. Crystal structure of khmaralite. Numbering of sites corresponds to column 1 of Table 3 (cf. column 1 , Table 2). Oriented to facilitate comparison of site numbering with that in the makarochkinite structure shown in Fig. 3. Green tetrahedra: $\mathrm{Si}, \mathrm{Si}>>\mathrm{Be}>\mathrm{Al}$ or $\mathrm{Si}>\mathrm{Al}$; yellow tetrahedra: $\mathrm{Al}$ or $\mathrm{Al}>\mathrm{Si}$; orange tetrahedra: $\mathrm{Be}=\mathrm{Si}+$ $\mathrm{Al}$ or $\mathrm{Be}>\mathrm{Al}$.

$\mathrm{Mg}, \mathrm{Fe} \rightleftharpoons \mathrm{Al}$, and $\mathrm{Cr} \rightleftharpoons \mathrm{Al}$ substitutions, and the heterovalent $(\mathrm{Mg}, \mathrm{Fe})+\mathrm{Si} \rightleftharpoons 2(\mathrm{Al}, \mathrm{Fe}, \mathrm{Cr})$ (Tschermaks) substitution (e.g. Deer et al., 1978; Higgins et al., 1979; Christy, 1989; Podlesskii et al., 2008), but Fe- and Cr-dominant analogues have not been reported in nature, nor has a Fe-dominant analogue been synthesized. Total $\mathrm{Fe}$ (as FeO) is in the range $0.05-16.55 \mathrm{wt} \%$ (minimum and maximum from Mangari area, Kenya and Vizianagaram, India, by Mercier et al., 1999 and Kamineni and Rao, 1988, respectively), but in most cases, both $\mathrm{Fe}^{3+}$ and $\mathrm{Fe}^{2+}$ are present, and their proportions are generally calculated from stoichiometry in the absence of a direct determination, e.g. by Mössbauer spectroscopy. Up to $2.77 \mathrm{Fe}^{2+}$ per 28 cations and $\mathrm{Fe}^{2+} /\left(\mathrm{Fe}^{2+}+\mathrm{Mg}\right)=0.36$ has been calculated from stoichiometry (Vizianagaram, India, Kamineni and Rao, 1988). Maximum $\mathrm{Fe}^{3+}$ contents directly measured by Mössbauer spectro- scopy are 0.85 per 28 cations in $\mathrm{Fe}^{2+}$-bearing sapphirine (Wilson Lake, Canada, Burns and Solberg, 1990) and 1.00 per 28 cations in a sapphirine lacking $\mathrm{Fe}^{2+}$ (Mautia Hill, Tanzania, McKie, 1963; Bancroft et al., 1968). The highest $\mathrm{Fe}^{3+}$ contents obtained by other methods are $1.93 \mathrm{Fe}^{3+}$ per 28 cations that Sahama et al. (1974) determined by wet chemistry in a sapphirine from Labwor, Uganda, and $1.89 \mathrm{Fe}^{3+}$ per 28 cations that Gnos and Kurz (1994) calculated in a sapphirine from the Semail ophiolite in the United Arab Emirates. However, these contents exceed the maximum that Steffen et al. (1984) were able to incorporate in synthetic Mg-sapphirine: $1.4 \mathrm{Fe}^{3+}$ per 28 cations. The presence of $\mathrm{Fe}^{2+}$ could favour incorporation of $\mathrm{Fe}^{3+}$; nonetheless, $\mathrm{Fe}^{3+}$ contents exceeding 1.4 need confirmation.

Using Mössbauer spectroscopy, Bancroft et al. (1968) and Steffen et al. (1984) located $\mathrm{Fe}^{3+}$ at 
TABLE 3. Simplified occupancies in the monoclinic minerals sapphirine- $2 M$ and khmaralite.

\begin{tabular}{|c|c|c|c|}
\hline S.G. & $\begin{array}{c}\text { Sapphirine- } 2 M \\
P 2_{1} / \mathrm{a}\end{array}$ & $\begin{array}{c}\text { Khmaralite } \\
\qquad P 2_{1} / c\end{array}$ & $\begin{array}{l}\text { Equivalent site* } \\
\qquad P \overline{1}\end{array}$ \\
\hline$T 3 * *$ & $\mathrm{Si}=\mathrm{Al}$ & $\mathrm{Si} \gg \mathrm{Be}>\mathrm{Al}$ & $T 1^{* *}$ \\
\hline$T 9 * *$ & - & $\mathrm{Be}>\mathrm{Al}$ & $T 1^{* *}$ \\
\hline$T 4$ & $\mathrm{Al}$ & $\mathrm{Si}>\mathrm{Al}$ & $T 2$ \\
\hline$T 10$ & - & $\mathrm{Al}$ & $T 2$ \\
\hline$T 1$ & $\mathrm{Al}$ & $\mathrm{Al}>\mathrm{Si}$ & $T 3$ \\
\hline$T 7$ & - & $\mathrm{Al}>\mathrm{Si}$ & $T 3$ \\
\hline$T 2 * *$ & $\mathrm{Si}$ & $\mathrm{Be}=\mathrm{Si}+\mathrm{Al}$ & $T 4 * *$ \\
\hline$T 8 * *$ & - & $\mathrm{Si}$ & $T 4 * *$ \\
\hline$T 6$ & $\mathrm{Al}>\mathrm{Si}$ & $\mathrm{Al}>\mathrm{Si}$ & $T 5$ \\
\hline$T 12$ & - & $\mathrm{Si}$ & $T 5$ \\
\hline$T 5$ & $\mathrm{Al}$ & $\mathrm{Al}>\mathrm{Si}$ & $T 6$ \\
\hline$T 11$ & - & $\mathrm{Al}$ & $T 6$ \\
\hline$M 8^{* *}$ & $\mathrm{Al}$ & $\mathrm{Al}$ & $M 1 * *, M 2 * *$ \\
\hline$M 16^{* *}$ & - & $\mathrm{Al}$ & \\
\hline$M 1$ & $\mathrm{Al}$ & $\mathrm{Al}$ & $M 3$ \\
\hline M9 & - & $\mathrm{Al}>\mathrm{Mg}$ & $M 3$ \\
\hline$M 2$ & $\mathrm{Al}$ & $\mathrm{Al}$ & M4 \\
\hline$M 10$ & - & $\mathrm{Al}>\mathrm{Mg}$ & M4 \\
\hline$M 4$ & $\mathrm{Mg}$ & $\mathrm{Mg}$ & M5 \\
\hline M12 & - & $\mathrm{Mg}$ & M5 \\
\hline$M 3$ & $\mathrm{Al}=\mathrm{Mg}$ & $\mathrm{Al}$ & M6 \\
\hline$M 11$ & - & $\mathrm{Mg}>\mathrm{Al}$ & M6 \\
\hline$M 7$ & $\mathrm{Al}$ & $\mathrm{Al}$ & $M 7$ \\
\hline$M 15$ & - & $\mathrm{Al}$ & $M 7$ \\
\hline$M 5$ & $\mathrm{Mg}$ & $\mathrm{Mg}>\mathrm{Al}$ & $M 8$ \\
\hline$M 13$ & - & $\mathrm{Mg}$ & $M 8$ \\
\hline$M 6$ & $\mathrm{Mg}$ & $\mathrm{Mg}$ & M9 \\
\hline$M 14$ & - & $\mathrm{Mg}$ & M9 \\
\hline
\end{tabular}

Sources given in Table 1. S.G. - space group. Equal sign (=) indicates approximately equal occupancy by the given constituents.

* In the other subgroups (Table 2).

** Indicates the most polymerized $T$ sites and non-wall octahedral sites.

tetrahedral sites, whereas Burns and Solberg (1990) concluded that $\mathrm{Fe}^{3+}$ occupies octahedral sites, which is consistent with $\mathrm{Fe}^{3+}$ occupancy determined by single-crystal refinement in sapphirine- $1 A$ from Wilson Lake, Canada (Merlino, 1980). Nonetheless, $\mathrm{Fe}^{3+}$ occupancy in sapphirine remains an open question.

The maximum $\mathrm{Cr}$ content is 1.42 per 28 cations (7.52 wt.\% $\mathrm{Cr}_{2} \mathrm{O}_{3}$, Fiskenæsset region, Greenland, Friend, 1982); the corresponding $\mathrm{Cr}^{3+} /\left(\mathrm{Cr}^{3+}+{ }^{\mathrm{vi}} \mathrm{Al}\right)$ ratio is 0.15 , i.e. $15 \%$ of a $\mathrm{Cr}$ end-member if $\mathrm{Cr}$ occupies only octahedral sites as suggested by the large octahedral site preference energy for $\mathrm{Cr}^{3+}$ (Navrotsky, 1975; Burns, 1993). Brigida et al. (2007) synthesized at $1340^{\circ} \mathrm{C}$ and 1 bar a sapphirine for which a formula with $83 \%$ of a $\mathrm{Cr}$ end-member,
$\mathrm{Mg}_{4}\left(\mathrm{Mg}_{3.8} \mathrm{Cr}_{6.7} \mathrm{Al}_{1.4}\right) \mathrm{O}_{4}\left[\mathrm{Si}_{4.1} \mathrm{Al}_{7.9} \mathrm{O}_{36}\right]$, can be written if all $\mathrm{Cr}^{3+}$ remains octahedrally coordinated at this temperature.

The Tschermak substitution is extensive in sapphirine. $\mathrm{Si}$ ranges from 1.71 to 4.49 per 28 cations in Be poor compositions; that is, a few compositions extend beyond the usual limits of $\mathrm{Si}=2$ and $\mathrm{Si}=4$ given for sapphirine, which correspond to the 2:2:1 and 3:5:1 compositions in terms of the (Mg,Fe,Mn)O:(Al,Fe,Cr, $)_{2} \mathrm{O}_{3}: \mathrm{SiO}_{2}$ ratio (Fig. 6). The great majority of compositions are closer to the 7:9:3 composition, which is given as the end-member in Table 1. Preference for this ratio is not surprising given the considerable octahedral ordering in sapphirine, i.e. $\mathrm{Mg}$ at $M 4$, $M 5$, and $M 6,{ }^{\text {vi }} \mathrm{Al}$ at $M 1, M 2, M 7, M 8$ and $M 9$, 


\section{E. S. GREW ET AL.}

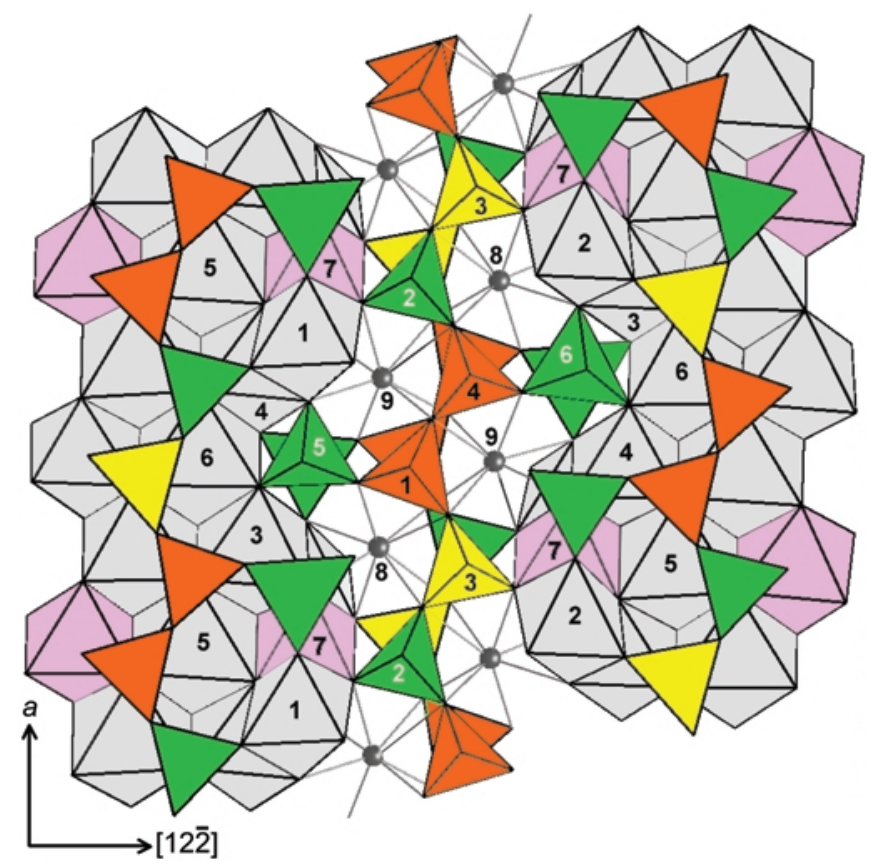

FIG. 3. Crystal structure of makarochkinite, which is representative of the structures of the centrosymmetric triclinic $\mathrm{Na}$ and $\mathrm{Ca}$ aenigmatite subgroup. Numbering of sites corresponds to column 3 of Table 2 (cf. column 4, Table 3). Green tetrahedra: $\mathrm{Si}$; yellow tetrahedra: $\mathrm{Si}=\mathrm{Al}$; orange tetrahedra: $\mathrm{Be}=\mathrm{Si}$; lavender octahedra: $\mathrm{Ti}$.

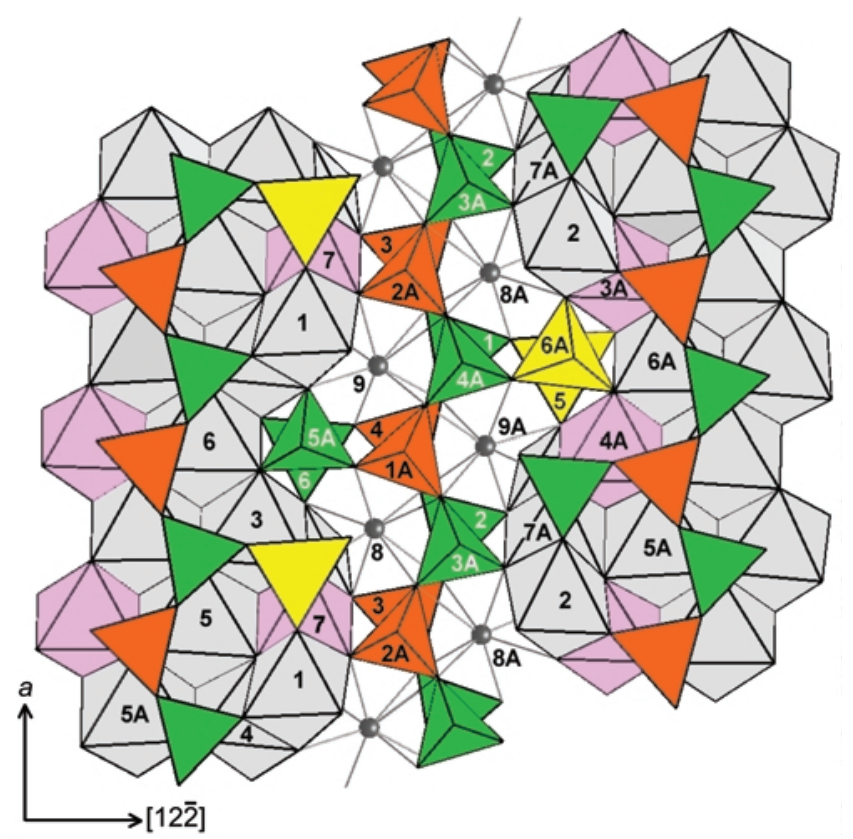

FIG. 4. Crystal structure of welshite, which is uniquely non-centrosymmetric Ca aenigmatite subgroup mineral. Numbering of sites corresponds to column 3 of Table 2, but sites are split (lettered vs. unlettered) due to absence of symmetry centre. Green tetrahedra: $\mathrm{Si}$; yellow tetrahedra: $\mathrm{Al}=\mathrm{Fe}$; orange tetrahedra: $\mathrm{Be}$ or $\mathrm{Be}=\mathrm{Al}$; lavender octahedra: Sb. 


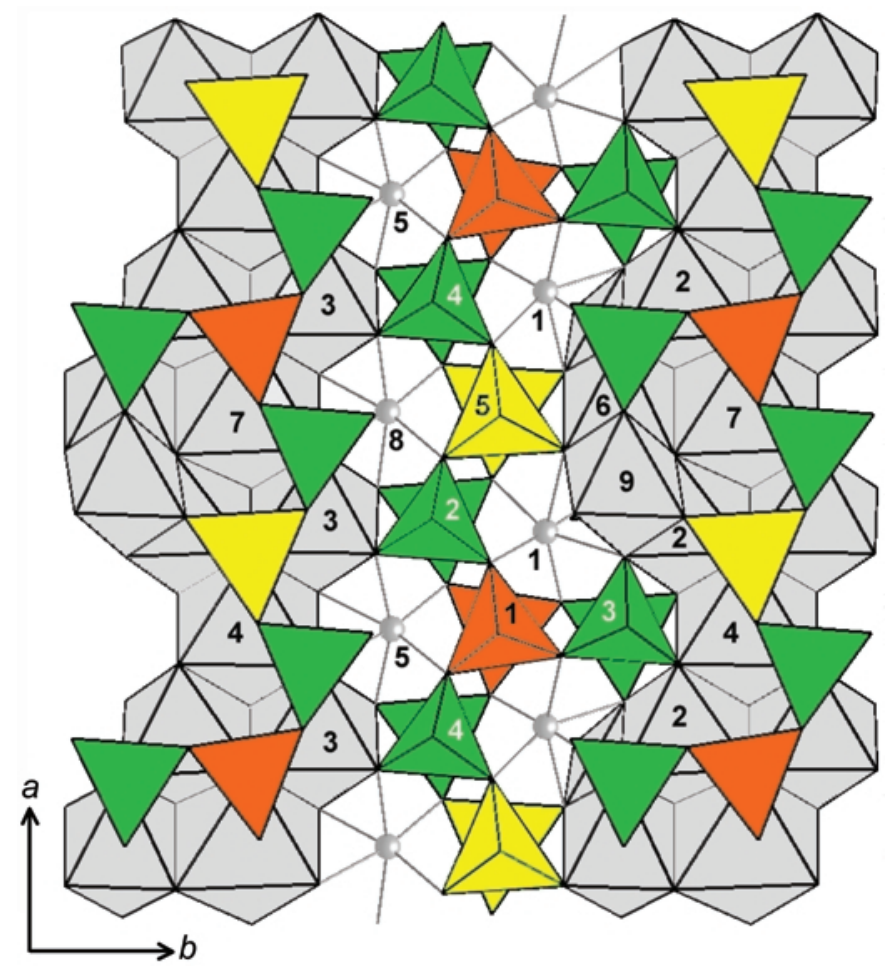

Fig. 5. Crystal structure of surinamite. Green tetrahedra: Si; yellow tetrahedra: Al; orange tetrahedra: Be.

with M3 generally split (Moore, 1969; Higgins and Ribbe, 1979; Merlino, 1980), summing to $\sim 7 \mathrm{Mg}$ and $\sim 9{ }^{\mathrm{vi}} \mathrm{Al}$ per 28 cations (Tables 2, 3). The tetrahedra are less well ordered (at least in the long range); the ratio of $\sim 3 \mathrm{Si}$ to $\sim 9{ }^{\mathrm{iv}} \mathrm{Al}$ in typical sapphirine is dictated by charge balance.

Calcium is generally a minor component of sapphirine, rarely exceeding 0.2 wt. $\% \mathrm{CaO}$ (Christy, 1989). However, Grew et al. (1992) reported B-rich sapphirine containing up to 5.4 wt. $\% \mathrm{CaO}$, which was attributed to $35 \%$ serendibite in solid solution.

Other constituents reported in sapphirine in amounts exceeding $1 \mathrm{wt} \% \%$ oxide are $\mathrm{MnO}$ (to 1.16 wt.\%, Madurai Block, south India; Tateishi et al., 2004) and $\mathrm{TiO}_{2}$ (to 1.25 wt.\% in terrestrial sapphirine, Vestfold Hills, Antarctica, Harley and Christy, 1995; and 1.60-2.30 wt.\% in sapphirine in plagioclase-olivine inclusions in the Allende meteorite, Sheng et al. 1991). Stoichiometric calculation of compositions of 'fassaite' in other plagioclase-olivine inclusions gave $\mathrm{Ti}^{3+}=$ $60-80 \%$ of total Ti (Sheng et al., 1991), suggesting that the $\mathrm{Ti}$ in the Allende sapphirine could also be trivalent in part $\left(\mathrm{Ti}^{3+}\right.$-bearing rhönite is also from Allende, but in Ca-Al-rich inclusions). Assuming $\mathrm{Ti}$ is trivalent improves stoichiometry of the two compositions reported by Sheng et al. (1991).

Beryllium is incorporated in sapphirine through the substitution $\mathrm{Be}+\mathrm{Si} \rightleftharpoons 2 \mathrm{Al}$, which relates the end-members for sapphirine and khmaralite given in Table 1 (Grew, 1981; Barbier et al., 1999, 2002; Christy et al., 2002; Grew et al., 2006). There appears an unbroken solid solution between Befree sapphirine and khmaralite containing $1.57 \mathrm{Be}$ per 28 cations, the maximum $\mathrm{Be}$ in natural khmaralite (Fig. 6). The superstructure with doubled chain periodicity characteristic of khmaralite appears at about $1 \mathrm{Be}$ per 28 cations (Grew et al., 2000). The octahedral composition of khmaralite is roughly $7\left(\mathrm{Mg}, \mathrm{Fe}^{2+}\right)$ and $9\left(\mathrm{Al}, \mathrm{Fe}^{3+}\right)$ (Table 3 ) as a consequence of the marked ordering at octahedral sites, an ordering very similar to that of sapphirine (Barbier et al., 1999). Moreover, sapphirine and khmaralite having intermediate Be contents plot close to a line joining the endmember sapphirine and khmaralite compositions 


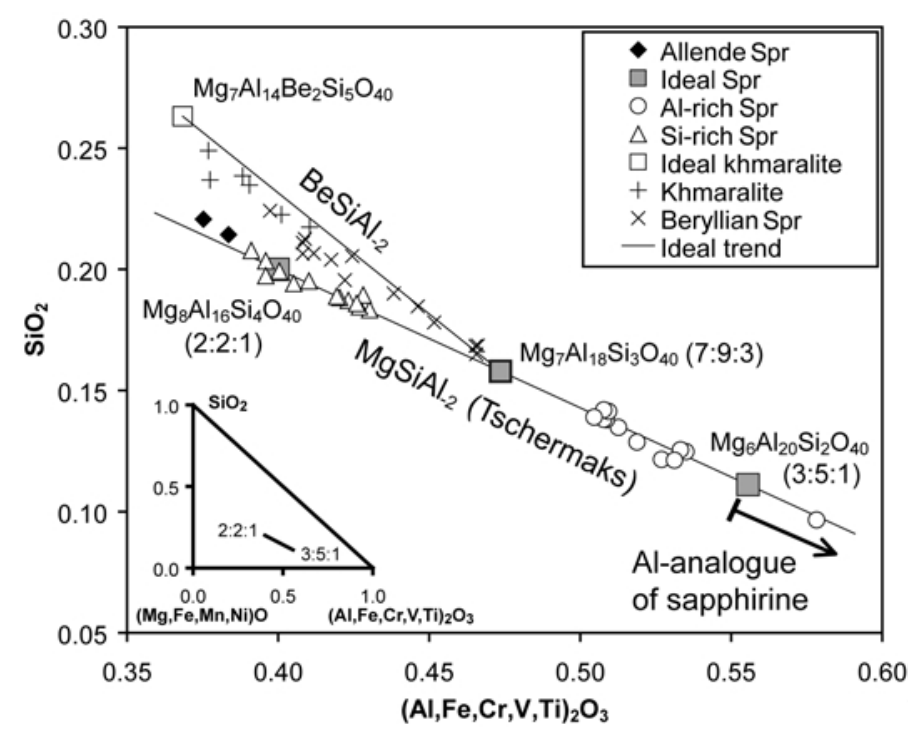

FIG. 6. Composition of sapphirine in terms of mole proportions $\mathrm{SiO}_{2},(\mathrm{Mg}, \mathrm{Fe}, \mathrm{Mn}, \mathrm{Ni}) \mathrm{O}$ and $(\mathrm{Al}, \mathrm{Fe}, \mathrm{Cr}, \mathrm{V}, \mathrm{Ti})_{2} \mathrm{O}_{3}$. $\mathrm{Al}$-analogue of sapphirine refers to a distinct species, yet unnamed, in which $\mathrm{Si}<2$ per 28 cations (Table 4). $\mathrm{BeSiAl}_{-2}$ and $\mathrm{MgSiAl}_{-2}$ refer to the substitutions $\mathrm{Be}+\mathrm{Si} \rightleftharpoons 2 \mathrm{Al}$ and $\mathrm{Mg}+\mathrm{Si} \rightleftharpoons 2 \mathrm{Al}$, respectively. Analyses of sapphirine selected to show only relatively Si-rich compositions (Dawson et al., 1997; Gnos and Kurz, 1994; Grew et al., 1994; Harley and Christy, 1995; Owen et al., 1988; Sajeev and Osanai, 2004; Sheng et al., 1991; Sills et al., 1983; Simon and Chopin, 2001) and Al-rich 'peraluminous' compositions (Godard and Mabit, 1998; Grew et al., 1988; Harley and Christy, 1995; Liati and Seidel, 1994; Nijland et al., 1998; Sabau et al., 2002; Schreyer and Abraham, 1975; Warren and Hensen, 1987); most sapphirine compositions are intermediate and have not been plotted. Ti is assumed to be trivalent only in the Allende sapphirine; in all others, Ti is assumed to be tetravalent. $\mathrm{Be}=1$ atom per 28 cations serves as the distinction between khmaralite and beryllian sapphirine. The plot includes all available compositions of khmaralite and Be-rich beryllian sapphirine (BeO $>1$ wt.\%) (Grew, 1981; Barbier et al., 1999; Grew et al., 2000 and unpublished data), but only selected compositions for beryllian sapphirine with Be contents between 1 and 0.2 wt.\% $\mathrm{BeO}$ (Grew et al., 2006).

(Fig. 6). Christy et al. (2002) synthesizied beryllian sapphirine in the $\mathrm{MgO}-\mathrm{BeO}-\mathrm{Al}_{2} \mathrm{O}_{3}$ $\mathrm{SiO}_{2}-\mathrm{H}_{2} \mathrm{O}$ system, but none had the superstructure characteristic of khmaralite. No more than 2 Be per 28 cations could be incorporated, and this amount only in starting compositions corresponding to the 2:2:1 composition plus $0.5 \mathrm{BeSiAl}_{-2}$. Two runs of this composition gave single-product sapphirine, implying its composition was $\mathrm{Mg}_{4}\left(\mathrm{Mg}_{4} \mathrm{Al}_{8}\right) \mathrm{O}_{4}$ $\left[\mathrm{Si}_{6} \mathrm{Be}_{2} \mathrm{Al}_{4} \mathrm{O}_{36}\right]$, but this was not confirmed by direct analysis.

Ca-poor sapphirine associated with prismatine at several localities incorporates up to $0.85 \mathrm{wt} . \%$ $\mathrm{B}_{2} \mathrm{O}_{3}$, corresponding to $0.35 \mathrm{~B}$ per 28 cations (Grew, 1986; Grew et al., 1990, 1991b). Bbearing sapphirine compositions are somewhat richer in $\mathrm{Si}$ than the 7:9:3 composition; the $\mathrm{B}$ contents correspond to $\sim 17 \%$ of a $\mathrm{B}$ analogue to the 7:9:3 composition, $\mathrm{Mg}_{4}\left(\mathrm{Mg}_{3} \mathrm{Al}_{9}\right) \mathrm{O}_{4}$ $\left[\mathrm{Si}_{3} \mathrm{~B}_{2} \mathrm{Al}_{7} \mathrm{O}_{36}\right]$. Ca-bearing sapphirine, to date only found at Johnsburg, New York, USA (Grew et al., 1992), contains significantly more B. A formula for the averaged composition with 2.08 wt. $\% \mathrm{~B}_{2} \mathrm{O}_{3}$ is $\mathrm{Mg}_{3.6} \mathrm{Ca}_{0.4}\left(\mathrm{Mg}_{2.8} \mathrm{Fe}_{0.1} \mathrm{Al}_{9}\right) \mathrm{O}_{4}$ $\left[\mathrm{Si}_{3.2} \mathrm{~B}_{0.8} \mathrm{Be}_{0.1} \mathrm{Al}_{7.9} \mathrm{O}_{36}\right]$, but the sapphirine is very heterogeneous compositionally. Examination by TEM led Grew et al. (1992) to conclude that the heterogeneous material is structurally a singlephase triclinic $\mathrm{Ca}-\mathrm{B}$ sapphirine; this phase appears to be a solid solution of serendibite and B-bearing sapphirine that subsequently exsolved Ca-richer material. The averaged composition (1.47 wt.\% $\mathrm{CaO}, 2.08$ wt. $\% \mathrm{~B}_{2} \mathrm{O}_{3}$ ) corresponds roughly to $10 \%$ serendibite and $25 \%$ $\mathrm{Mg}_{4}\left(\mathrm{Mg}_{3} \mathrm{Al}_{9}\right) \mathrm{O}_{4}\left[\mathrm{Si}_{3} \mathrm{~B}_{2} \mathrm{Al}_{7} \mathrm{O}_{36}\right]$ in solid solution.

\section{Aenigmatite, wilkinsonite, krinovite}

Aenigmatite and wilkinsonite constitute a continuous solid solution series linked predominantly by 
TABLE 4. Classification scheme for the sapphirine supergroup.

\begin{tabular}{|c|c|c|c|c|c|}
\hline $\begin{array}{l}\text { Polysome } \\
\text { (group) }\end{array}$ & $\begin{array}{l}\text { Largest } M \\
\text { (subgroup) }\end{array}$ & $\begin{array}{l}\text { Most shared } \\
\text { edges }\end{array}$ & $\mathrm{Q}^{3} T$ & $X_{\mathrm{Mg}}$ & $\begin{array}{c}\text { Mineral or } \\
\text { possible mineral }\end{array}$ \\
\hline \multicolumn{6}{|l|}{ Sapphirine } \\
\hline & $M 5, M 6$ & $M 7$ & $T 2, T 3$ & & \\
\hline & Sapphirine & & & & \\
\hline$<\mathrm{SP}>$ & $\mathrm{Mg}$ & $\mathrm{Al}$ & $\mathrm{Si}>\mathrm{Al}$ & $>0.5$ & SAPPHIRINE \\
\hline$<\mathrm{SP}>$ & $\mathrm{Mg}$ & Al & $\mathrm{Al}>\mathrm{Si}$ & $>0.5$ & Al analogue of sapphirine \\
\hline \multirow[t]{3}{*}{$<\mathrm{SP}>$} & $\mathrm{Mg}$ & $\mathrm{Al}$ & $\mathrm{Be}=1^{1}$ & $>0.5$ & KHMARALITE $^{2}$ \\
\hline & $M 8, M 9$ & $M 7$ & $T 1, T 4$ & & \\
\hline & Aenigmatite & & & & \\
\hline$<\mathrm{SP}>$ & $\mathrm{Na}$ & $\mathrm{Ti}^{4+}$ & $\mathrm{Si}$ & $<0.5$ & AENIGMATITE \\
\hline$<\mathrm{SP}>$ & $\mathrm{Na}$ & $\mathrm{Fe}^{3+}$ & $\mathrm{Si}$ & $<0.5$ & WILKINSONITE \\
\hline$<\mathrm{SP}>$ & $\mathrm{Na}$ & $\mathrm{Fe}^{3+}$ & $\mathrm{Si}$ & $>0.5$ & Mg analogue of wilkinsonite \\
\hline \multirow[t]{2}{*}{$<\mathrm{SP}>$} & $\mathrm{Na}$ & $\mathrm{Cr}$ & $\mathrm{Si}$ & $>0.5$ & KRINOVITE \\
\hline & Rhönite & & & & \\
\hline$<\mathrm{SP}>$ & $\mathrm{Ca}$ & $\mathrm{Ti}^{4+}$ & $\mathrm{Si}>\mathrm{Al}$ & $>0.5$ & RHÖNITE \\
\hline$<\mathrm{SP}>$ & $\mathrm{Ca}$ & $\mathrm{Ti}^{4+}$ & $\mathrm{Si}>\mathrm{Al}$ & $<0.5$ & $\mathrm{Fe}^{2+}$ analogue of rhönite \\
\hline$<\mathrm{SP}>$ & $\mathrm{Ca}$ & $\mathrm{Ti}^{4+}$ & $\mathrm{Be}=1^{1}$ & $<0.5$ & MAKAROCHKINITE \\
\hline$<\mathrm{SP}>$ & $\mathrm{Ca}$ & $\mathrm{Fe}^{3+}$ & $\mathrm{Si}, \mathrm{Al}$ & $>0.5$ & DORRITE \\
\hline$<\mathrm{SP}>$ & $\mathrm{Ca}$ & $\mathrm{Fe}^{3+}$ & $\mathrm{Be}=1^{1}$ & $<0.5$ & HØGTUVAITE \\
\hline$<\mathrm{SP}>$ & $\mathrm{Ca}$ & $\mathrm{Mg}$ & $\mathrm{Si}, \mathrm{Al}$ & $>0.5$ & Unnamed $^{3}$ \\
\hline$<\mathrm{SP}>$ & $\mathrm{Ca}$ & $\mathrm{Al}$ & $\mathrm{B}=1^{1}$ & $>0.5$ & SERENDIBITE \\
\hline \multirow[t]{2}{*}{$<\mathrm{SP}>$} & $\mathrm{Ca}$ & $\mathrm{Sb}, \mathrm{Mg}$ & $\mathrm{Be}=1^{4}$ & $>0.5$ & WELSHITE $^{4}$ \\
\hline & Unnamed & & & & \\
\hline$<\mathrm{SP}>$ & $\mathrm{Fe}^{2+}$ & $?$ & $?$ & $<0.5$ & Unnamed Fe-Sn-Ga-Ge \\
\hline \multicolumn{6}{|l|}{ Surinamite } \\
\hline & $M 1, M 5, M 8$ & M6 & $T 1$ & & \\
\hline$<$ PPS $>$ & $\mathrm{Mg}$ & $\mathrm{Al}$ & $\mathrm{Be}$ & $>0.5$ & SURINAMITE \\
\hline$<$ PPS $>$ & $\mathrm{Mg}$ & $\mathrm{Al}$ & $\mathrm{Al}$ or $\mathrm{Si}$ & $>0.5$ & Be-free analogue of surinamite \\
\hline
\end{tabular}

Columns are 1 - Group name and polysome symbol; 2 - Subgroup name and occupant of two or three largest $M$ sites, 3 - Occupants of $M$ site with most shared edges, 4 - Occupants of most polymerized $T$ sites. $5-X_{\mathrm{Mg}}=$ atomic $\mathrm{Mg} /\left(\mathrm{Mg}+\mathrm{Fe}^{2+}\right)$ at other $M$ sites. Names of minerals approved by the CNMNC (CNMMN) are in capital letters.

${ }^{1}$ Total Be or B occupancy at the two $T$ sites considered together for the end-member composition given in Table 1. ${ }^{2}$ Khmaralite contains two sapphirine sub-cells $(M 1-8, T 1-6$ and $M 9-16, T 7-12)$. Be $>0.5$ at each of $T 2$ and $T 9$. ${ }^{3} \mathrm{Ti}^{3+}$-bearing $\mathrm{Mg}$-analogue of rhönite.

${ }^{4}$ Welshite has $P 1$ symmetry so that the $T 1-T 6$ and $M 3-M 9$ sites are doubled. Be $=1$ at $T 1 \mathrm{~A}$ and $T 4$, contributing $2 \mathrm{Be}$ to the end-member formula (Table 1) from these sites; $\mathrm{Sb}=1$ at $M 7$ and $\mathrm{Mg}=1$ at $M 7 \mathrm{~A}$.

the substitution $\mathrm{Fe}^{2+}+\mathrm{Ti} \rightleftharpoons 2 \mathrm{Fe}^{3+}$ (Hodges and Barker, 1973; Larsen, 1977; Duggan, 1990). Homovalent substitutions, notably $\mathrm{Mn}$ or $\mathrm{Mg}$ for $\mathrm{Fe}^{2+}$ and $\mathrm{Al}$ for $\mathrm{Fe}^{3+}$, are limited in extent. For example, Ridolfi et al. (2006) reported an aenigmatite in one sample of a silica-saturated peralkaline syenite autolith, from Kilombe volcano, Kenya, with 5.98-7.93 wt.\% $\mathrm{MnO}$, which corresponds to 1.428 and $1.894 \mathrm{Mn}$ per 28 cations and $\mathrm{Mn} /\left(\mathrm{Mn}+\mathrm{Fe}^{2+}\right)=0.15$ and 0.20 , respectively, and is the richest in Mn yet reported. In most cases, $\mathrm{Mg}$ contents are lower, mostly $<1$ wt. $\% \mathrm{MgO}$, but with two notable exceptions. Price et al. (1985) and Price (pers. comm.) reported 8.88-10.61 wt.\% $\mathrm{MgO}$, corresponding to $3.53-4.21 \mathrm{Mg}$ per 28 cations and $\mathrm{Mg} /\left(\mathrm{Mg}+\mathrm{Fe}^{2+}\right)=0.43-0.48$ in aenigmatite from nepheline syenite on Mount Kenya. Aenigmatite found in an albite clast in the Kaidun meteorite, a breccia, contains 3.64-6.81 wt.\% $\mathrm{MgO}$, corre- 
sponding to $1.50-2.71 \mathrm{Mg}$ per 28 cations and $\mathrm{Mg} /\left(\mathrm{Mg}+\mathrm{Fe}^{2+}\right)=0.16-0.29$, Ivanov et al., 2003; Zolensky and Ivanov, 2003). Bischoff et al. (1993) reported $3.7 \mathrm{wt} \% \mathrm{MgO}$ in a phase in an alkali-granite clast in meteorite Adzhi-Bogdo; this phase is probably aenigmatite (Ivanov et al., 2003). With $\mathrm{Mg} /\left(\mathrm{Mg}+\mathrm{Fe}^{2+}\right)=0.06$ (Ivanov et al. 2003; Zolensky and Ivanov, 2003), wilkinsonite associated with aenigmatite in the Kaidun meteorite is more magnesian than any terrestrial material with the exception of wilkinsonite containing 5.50 wt. $\% \mathrm{MgO}$, i.e. $\mathrm{Mg} /\left(\mathrm{Mg}+\mathrm{Fe}^{2+}\right)$ $=0.53$, from a syenitic ejectum, Wonchi volcano, Ethiopia (Gaeta and Mottana, 1991). In contrast to the magnesian aenigmatite from Mount Kenya, in which divalent cations total $8.5-9.0$ per 28 cations, close to the ideal 10 , divalent cations total only 5.1 in the Wonchi wilkinsonite, significantly less than the 8 per 28 cations in ideal wilkinsonite.

Aenigmatite and wilkinsonite deviate to some degree from ideal stoichiometry. Ti exceeds 2 atoms per 28 cations in some samples, and most analyses give $\mathrm{Fe}^{3+}$ in excess of that expected from $\mathrm{Fe}^{2+}+\mathrm{Ti} \rightleftharpoons 2 \mathrm{Fe}^{3+}$ (Fig. 7a). Nonstoichiometry also results from incorporation of constituents other than $\mathrm{Fe}, \mathrm{Ti}, \mathrm{Mg}, \mathrm{Mn}, \mathrm{Na}$ and $\mathrm{Si}$. The most important of these are $\mathrm{Ca}$ and $\mathrm{Al}$, e.g. $\mathrm{Ca}$ content ranges from negligible to nearly 1 atom per 28 cations, i.e. $25 \%$ substitution of $\mathrm{Na}$ by $\mathrm{Ca}$ (Fig. 8). In most analyses the sum of $\mathrm{Na}$ $+\mathrm{Ca}+\mathrm{K}$ ranges from 4.0 to 4.2 atoms, i.e. somewhat in excess of stoichiometry with more scatter at low $\mathrm{Ca}$ content. This excess in electron microprobe analyses could be due to improper standardization of $\mathrm{Na}$ as Larsen (1977) suggested. Aluminum content ranges from 1.5 to 6 times $\mathrm{Ca}$ content, and is close to 1.5 in Ca-rich analyses (Fig. $8 b$ ). $\mathrm{K}_{2} \mathrm{O}$ contents greater than 0.2 wt.\% $(>0.07 \mathrm{~K}$ per 28 cations) are rarely reported, and only in wet chemical analyses with one exception ( 0.75 wt. $\%$ or $0.28 \mathrm{~K}$ per 28 cations, Wonchi wilkinsonite, Gaeta and Mottana, 1991).

Larsen (1977) invoked the following four coupled substitutions to account for compositional variation in aenigmatite from the Ilímaussaq complex, Greenland:

$$
\begin{aligned}
& { }^{\mathrm{vi}} \mathrm{Ti}+{ }^{\mathrm{vi}} \mathrm{Fe}^{2+} \rightleftharpoons 2^{\mathrm{vi}} \mathrm{Fe}^{3+} \\
& \mathrm{Ca}+{ }^{\mathrm{iv}} \mathrm{Al} \rightleftharpoons \mathrm{Na}+{ }^{\mathrm{iv}} \mathrm{Si} \\
& { }^{\mathrm{vi}} \mathrm{Fe}^{2+}+{ }^{\mathrm{iv}} \mathrm{Si} \rightleftharpoons{ }^{\mathrm{vi}} \mathrm{Fe}^{3+}+{ }^{\mathrm{iv}} \mathrm{Al} \\
& { }^{\mathrm{vi}} \mathrm{Fe}^{2+}+{ }^{\mathrm{iv}} \mathrm{Si} \rightleftharpoons{ }^{\mathrm{vi}} \mathrm{Fe}^{3+}+{ }^{\mathrm{iv}} \mathrm{Fe}^{3+}
\end{aligned}
$$

Taking into account the refinement of wilkinsonite (Burt et al., 2007), substitution 1 can be written more specifically as ${ }^{M 7} \mathrm{Ti}+{ }^{M 1, M 2} \mathrm{Fe}^{2+} \rightleftharpoons$ ${ }^{M 7} \mathrm{Fe}^{3+}+{ }^{M 1, M 2} \mathrm{Fe}^{3+}$, which is probably the most important substitution relating the two minerals. Substitutions 3 and 4 can explain why analyses from other areas as well as Ilímaussaq give more $\mathrm{Fe}^{3+}$ than predicted by substitution 1 (e.g. Vesterøya, Norway, Grew et al., 2008) and why Al > Ca. Substitution 2 links end-member aenigmatite with our suggested end-member composition for the $\mathrm{Fe}^{2+}$ analogue of rhönite (Table 1), whereas substitutions 2 and 3 working in tandem at a $2: 1$ ratio, together with $\mathrm{Mg} \rightleftharpoons \mathrm{Fe}^{2+}$, link end-member aenigmatite with the composition given for rhönite in Table 1. The trend at greater $\mathrm{Ca}$ contents $(\mathrm{Al} / \mathrm{Ca}=1.5$, Fig. $8 b)$ is consistent with the latter, i.e. over $20 \%$ solid solution of a $\mathrm{Fe}^{2+}$-dominant analogue of the rhönite composition given in Table 1 .

The new structure refinement and Mössbauer data (Grew et al., 2008) confirm earlier suggestions based on Mössbauer spectroscopy (Choi, 1983; Choi and Burns, 1983; Burns and Solberg, 1990) that tetrahedral $\mathrm{Fe}^{3+}$ is present in aenigmatite. The sum $\mathrm{Si}+\mathrm{Al}$ is significantly less than 12 in other aenigmatite samples (Fig. $7 b$ ), and this deficit at tetrahedral sites is best explained by tetrahedral $\mathrm{Fe}^{3+}$ in the absence of other tetrahedrally coordinated cations such as $\mathrm{Be}$ and $\mathrm{B}$. Thus, substitution 4, which introduces tetrahedral $\mathrm{Fe}^{3+}$, undoubtedly plays a role, albeit minor, in aenigmatite crystal chemistry.

$\mathrm{Nb}, \mathrm{Zr}$, Sn and $\mathrm{Zn}$ are reported in amounts up to 1 wt.\% oxide, sometimes more (e.g. 3.72 wt.\% $\mathrm{Nb}_{2} \mathrm{O}_{5}$ in wilkinsonite, corresponding to $0.49 \mathrm{Nb}$ per 28 cations; Duggan, 1990). Other elements, notably $\mathrm{Li}$ (to 0.06 wt. $\% \mathrm{Li}_{2} \mathrm{O}$, corresponding to $0.07 \mathrm{Li}$ per 28 cations, Howie and Walsh, 1981; Raade and Larsen, 1980; Åsheim et al., 2008), could also be significant; but relatively few papers report analyses of these minor constituents. Åsheim et al. (2008) reported other trace element contents in aenigmatite from the Larvik plutonic complex, Norway, including 28-31 ppm Be and 11-92 ppm B (cf. 20 ppm Be, Lovozero, Vlasov et al., 1966). Because the ferric/ferrous ratio in most samples is calculated from stoichiometry, ignoring $\mathrm{Nb}, \mathrm{Zr}, \mathrm{Sn}, \mathrm{Zn}$ and $\mathrm{Li}$ can lead to errors in calculating $\mathrm{Fe}^{3+}$ content, above and beyond errors inherent in the calculation itself.

Only one analysis of krinovite has been reported (Olsen and Fuchs, 1968). Its composition approaches that of the end-member with 5\% substitution of $\mathrm{Mg}$ by $\mathrm{Fe}$ (Bonaccorsi et al., 

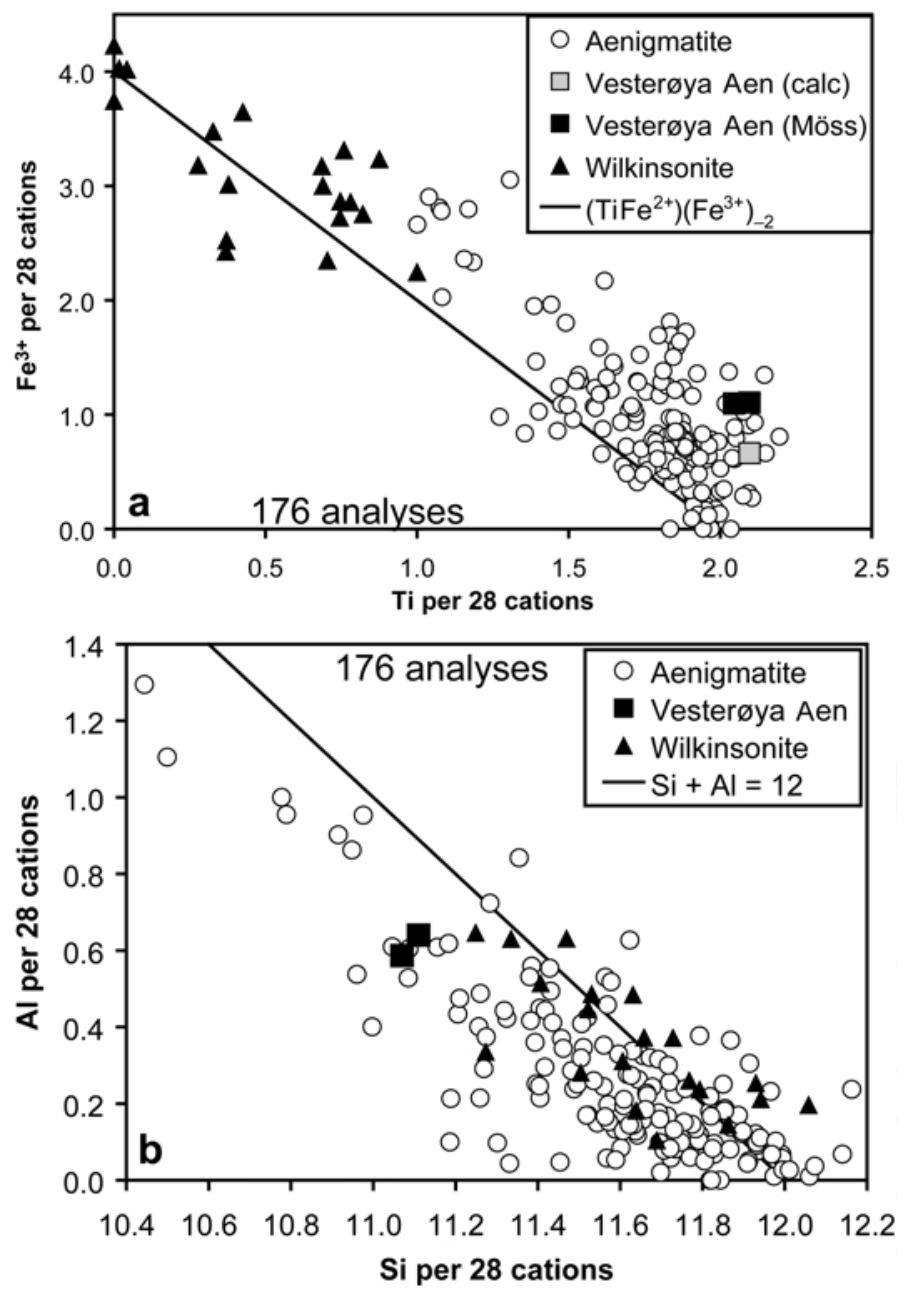

Fig. 7. Compositional variations of aenigmatite (Aen) and wilkinsonite as functions of $\mathrm{Ti}$ and $\mathrm{Si} .\left(\mathrm{TiFe}^{2+}\right)\left(\mathrm{Fe}^{3+}\right)_{-2}$ in (a) indicates the substitution ${ }^{\mathrm{vi}} \mathrm{Ti}+{ }^{\mathrm{vi}} \mathrm{Fe}^{2+} \rightleftharpoons 2{ }^{\mathrm{vi}} \mathrm{Fe}^{3+}$ relating aenigmatite and wilkinsonite. Vesterøya Aen refers to electron microprobe data on a sample from Vesterøya, Norway from which a crystal was used to newly refine the structure $\left(\mathrm{Fe}^{3+} / \Sigma \mathrm{Fe}\right.$ calculated from chemical data and measured by Mössbauer spectroscopy, Grew et al., 2008). We calculated $\mathrm{Fe}^{3+} / \mathrm{Fe}^{2+}$ ratio in all the other analyses by assuming 28 cations and 40 oxygens whether or not $\mathrm{Fe}^{3+}$ had been measured directly in wet chemical analyses or calculated by the original authors from electron microprobe analyses. Sources of other data: Abbott (1967); Avanzinelli et al. (2004); Barker and Hodges (1977); Barker (unpublished data); Birkett et al. (1996); Bischoff et al. (1993); Bohrson and Reid (1997); Borley (1976); Bryan (1969); Bryan and Stevens (1973); Bulakh (1997); Carmichael (1962); Curtis and Currie, 1981; Dawson (1997); Downs (2006); Duggan (1990); Ewart et al. (1968); Farges et al. (1994); Ferguson (1978); Gaeta and Mottana (1991); Gibb and Henderson (1996); Grapes et al. (1979); Henderson et al. (1989); Howie and Walsh (1981); Ike (1985); Ivanov et al. (2003); Jones (1984); Jørgensen (1987); Kelsey and McKie (1964); Krivdik and Tkachuk (1988); Larsen (1977); Lindsley and Haggerty (1970); Mahood and Stimac (1990), Marks and Mark1 (2003); Marsh (1975); Mitrofanov and Afanas'yeva (1966); Nash et al. (1969); Nicholls and Carmichael (1969); Nkoumbou et al. (1995); Platt and Woolley (1986); Powell (1978); Price (personal communication, 2007); Price et al. (1985); Ren et al. (2006); Stolz (1986); Velde (1978); Vlasov et al. (1966); White et al. (2005); Yagi and Souther (1974); Zies

(1966). 

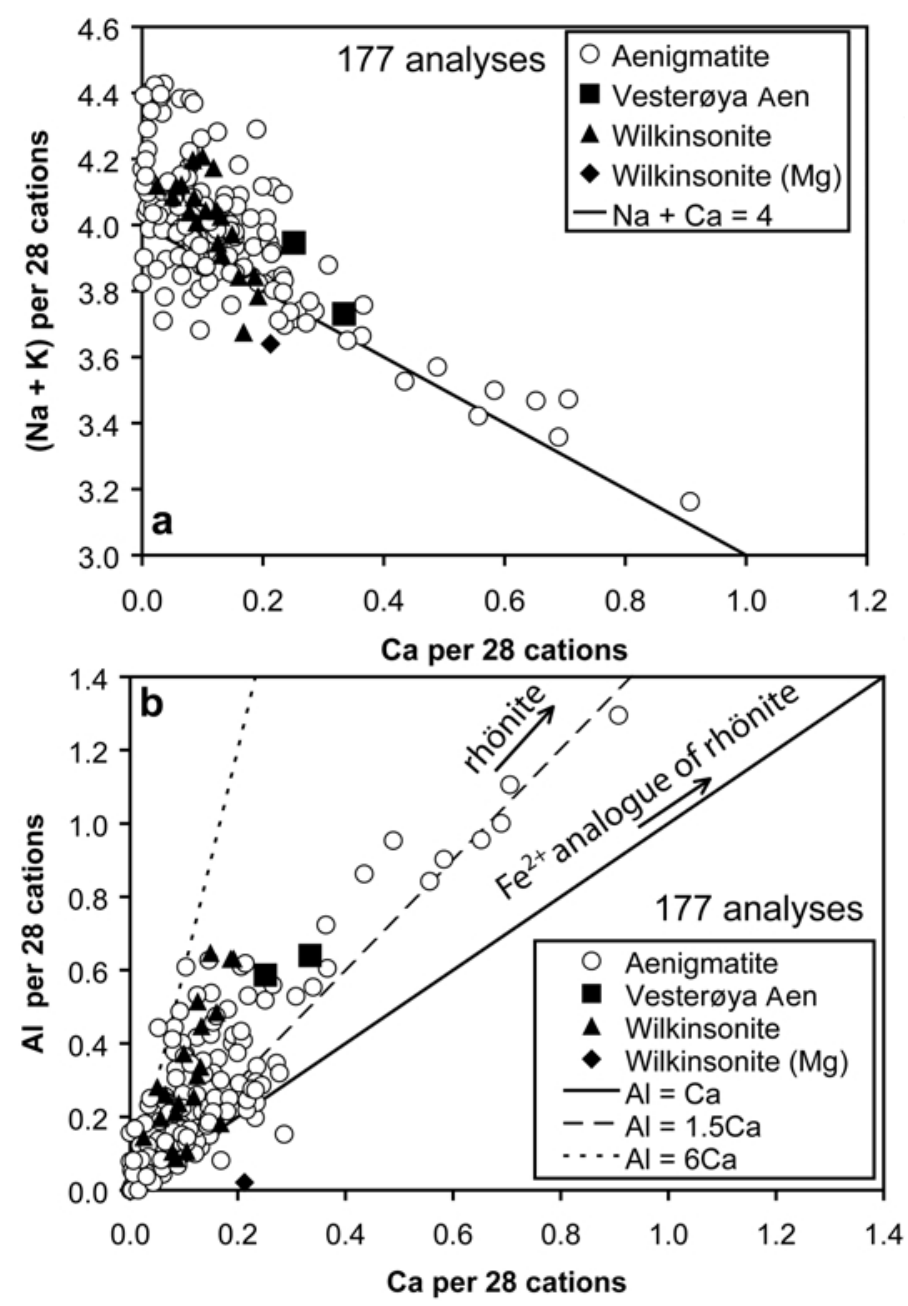

FIG. 8. Compositional variations of aenigmatite (Aen) and wilkinsonite as a function of Ca. Arrows in $(b)$ point to the end-member composition of rhönite plus $\mathrm{Fe}^{2+} \mathrm{Mg}_{-1}$ and to the suggested end-member composition of the $\mathrm{Fe}^{2+}$ analogue of rhönite (Table 1). Vesterøya Aen refers to electron microprobe data on a sample from Vesterøya, Norway from which a crystal was used to newly refine the structure (Grew et al., 2008). Wilkinsonite (Mg) refers to the unnamed Mg-dominant analogue reported by Gaeta and Mottana (1991). Other sources are given in the caption to Fig. 7.

1989); other minor constituents are $\mathrm{Al}_{2} \mathrm{O}_{3}$ (0.6 wt.\%), $\mathrm{TiO}_{2}$ (0.5 wt.\%), $\mathrm{CaO}$ and $\mathrm{MnO}$ (0.1 wt.\% each).

Rhönite, dorrite, makarochkinite, høgtuvaite

The Be-poor ferromagnesian silicates rhönite (including the $\mathrm{Fe}^{2+}$-dominant analogue and rhönite in Ca-Al-rich inclusions in the Allende meteorite) and dorrite appear to constitute a complex solid solution involving several compo- nents (e.g. Cosca et al., 1988; Kunzmann, 1989, 1999). There is no evidence for a miscibility gap between dorrite and rhönite (Fig. 9) as Cosca et al. (1988) suggested on the basis of the many fewer compositions available to them. Total $\mathrm{Ti}$ ranges from nearly negligible in dorrite to over 4.5 atoms per 28 cations in Allende rhönite. However, there is a major change at $\mathrm{Ti} \approx 3.1$ atoms. For $\mathrm{Ti}<3.1$, with one exception (see below), formula calculation using stoichiometry and assuming all $\mathrm{Ti}$ is $\mathrm{Ti}^{4+}$ gives $\mathrm{Fe}^{3+}$, whereas 


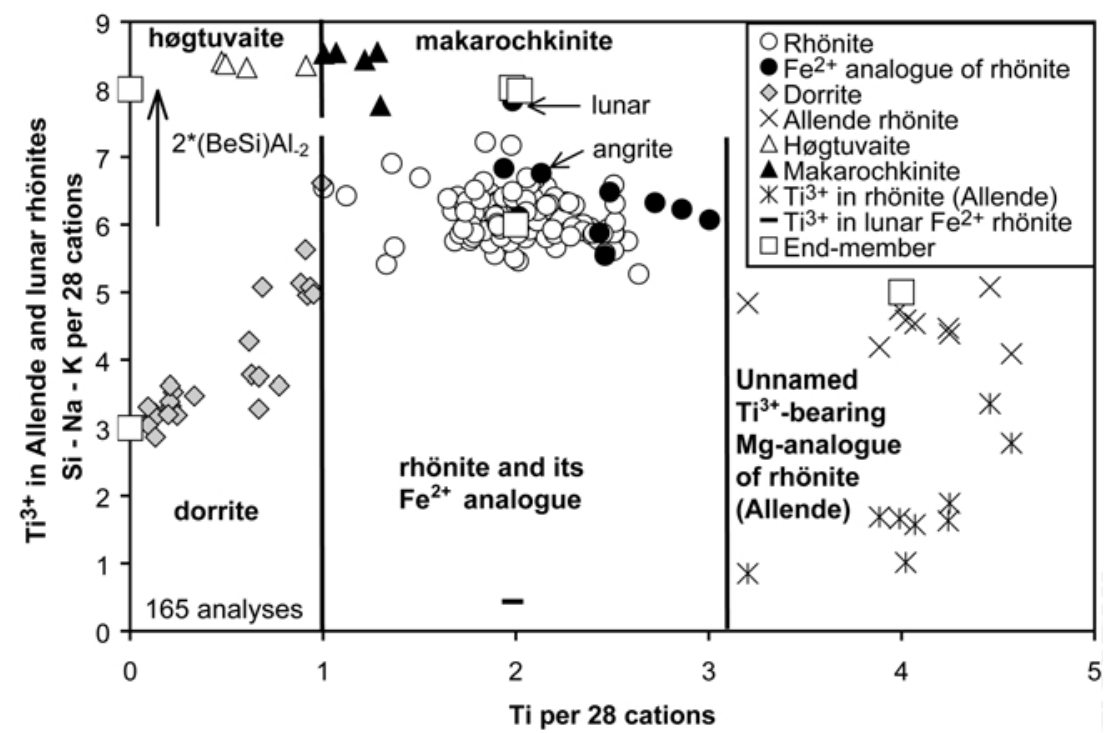

FIG. 9. Si and Ti contents of dorrite, rhönite and its $\mathrm{Fe}^{2+}$ analogue and its $\mathrm{Ti}^{3+}$-bearing $\mathrm{Mg}$ analogue (Allende), høgtuvaite and makarochkinite (modelled on Kunzmann, 1999, Fig. 7 and Grew et al., 2005, Fig. 5). Except for analyses of makarochkinite and høgtuvaite for which Mössbauer data were available (Grauch et al., 1994; Grew et al., 2005), we calculated $\mathrm{Fe}^{3+} / \mathrm{Fe}^{2+}$ ratio by assuming 28 cations and 40 oxygens (unless 28 cations gave all $\mathrm{Fe}$ as $\mathrm{Fe}^{3+}$ ) whether or not $\mathrm{Fe}^{3+}$ had been measured directly in wet chemical analyses or calculated by the original authors from electron microprobe analyses. End-member compositions are given in Table 1 (compositions for makarochkinite and $\mathrm{Fe}^{2+}$ analogue of rhönite are superimposed, and thus the plotted squares are slightly displaced from the ideal value). Vertical arrow shows the effect of the substitution $\mathrm{Be}+\mathrm{Si} \rightleftharpoons 2 \mathrm{Al}$, which relates høgtuvaite and makarochkinite to rhönite and its unnamed $\mathrm{Fe}^{2+}$ analogue. The vertical lines indicate species boundaries for the names in bold. Included with dorrite (diamonds) are the $\mathrm{Fe}^{3+}$-rich 'melilite' of Foit et al. (1987), 'mineral $\mathrm{X}_{1}$ ' of Havette et al. (1982) and several analyses given as 'rhönite' by Kunzmann (1989), Rondorf (1989) and Johnston and Stout, 1984). Two compositions approach a Fe-analogue: one from Luna 24 regolith (lunar, Treiman, 2008), and another from angrite NWA 4590, a meteorite (angrite, Kuehner and Irving, 2007). Sources of the other compositional data: Alletti et al. (2005); Boivin (1980); Bonaccorsi et al. (1990); Brooks et al. (1979); Cameron et al. (1970); Corsaro et al. (2007). Cosca et al. (1988); Downes et al. (1995); Fodor and Hanan (2000); Fuchs (1971, 1978); Gamble and Kyle (1987); Grapes et al. (2003); Grew et al. (2005); Grünhagen and Seck (1972); Hurai et al (2007); Jannot et al. (2005); Johnston and Stout (1985); Kunzmann (1989), Kyle and Price (1975); Magonthier and Velde (1976); Mao and Bell (1974); Mason and Taylor (1982); Nédli and Tóth (2003); Nishio et al. (1985); Olsson (1983); Polyakov et al. (1986); Prestvik et al. (1999); Simon et al. (1999); Soellner (1907); Timina et al. (2006); Warren et al. (2006).

for $\mathrm{Ti}>3.1$, this stoichiometric calculation gives negative $\mathrm{Fe}^{3+}$. If we assume that all $\mathrm{Fe}$ is $\mathrm{Fe}^{2+}$, then compositions with $\mathrm{Ti}>3.1$ give both $\mathrm{Ti}^{4+}$ and $\mathrm{Ti}^{3+}$, and the latter increases with increasing total Ti. The only natural phase containing more than $3.1 \mathrm{Ti}$ and calculated $\mathrm{Ti}^{3+}$ is rhönite from the Allende meteorite. 'Baykovite' ('baikovite'), a component of Si-Ti slag, is an isostructural phase containing $5.82-6.01 \mathrm{Ti}$, of which $3.63-3.76$ is $\mathrm{Ti}^{3+}$ per 28 cations (Rudneva and Malysheva, 1960; Arakcheeva, 1995); an average formula from the reported data is $\mathrm{Ca}_{4}\left(\mathrm{Ca}_{0.3} \mathrm{Mg}_{5.55} \mathrm{Al}_{0.24}\right.$ $\left.\mathrm{Ti}_{3.69}^{3+} \mathrm{Ti}_{2.23}^{4+}\right) \mathrm{O}_{4}\left[\mathrm{Si}_{3.6} \mathrm{Al}_{8.4} \mathrm{O}_{36}\right]$.
Total $\mathrm{Ca}+\mathrm{Na}+\mathrm{K}$ ( $\mathrm{K}$ is much subordinate to $\mathrm{Na})$ sum close to 4 atoms per 28 cations in rhönite and dorrite (except for 5 of 8 compositions in the type dorrite sample), with up to nearly $40 \%$ substitution of $\mathrm{Ca}$ by $\mathrm{Na}+\mathrm{K}$ (Fig. 10). Corsaro et al. (2007) reported up to $1.3 \mathrm{wt} . \% \mathrm{SrO}(0.21 \mathrm{Sr}$ per 28 cations). Al decreases in a 1:1 ratio with $\mathrm{Ca}$ (Fig. 11), which is not consistent with solid solution towards aenigmatite (cf. Fig. 8b). Most dorrite contains relatively little $\mathrm{Na}+\mathrm{K}$, but $\mathrm{Ca}>4$ atoms per 28 cations, implying $\mathrm{Ca}$ substitution at sites other than $M 8$ and $M 9$; up to 0.9 excess $\mathrm{Ca}$ per 28 cations is ordered at M5 in SFCA and 


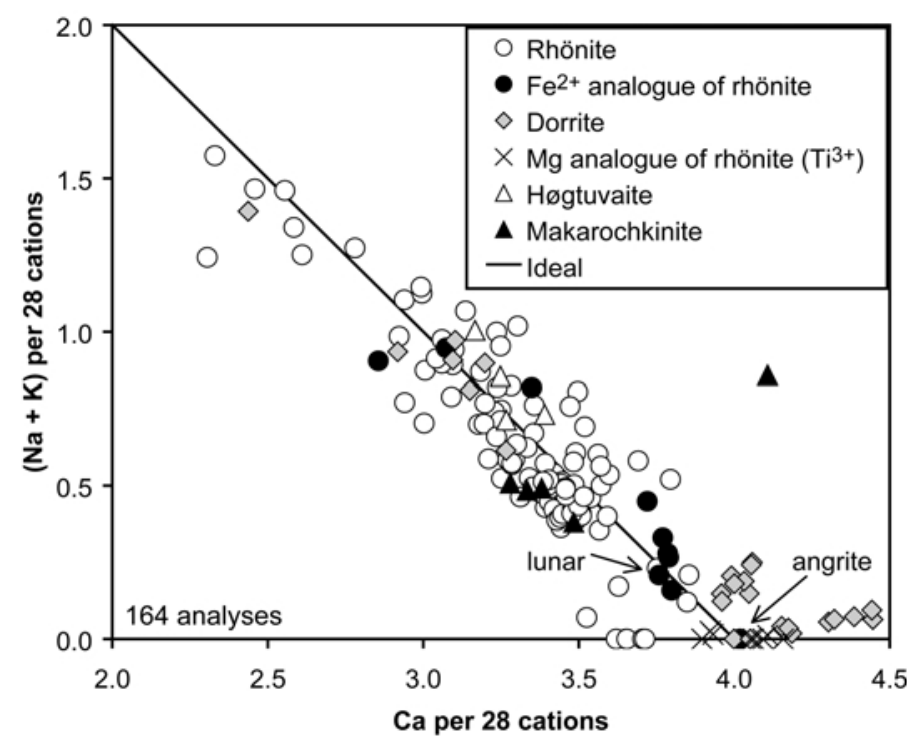

FIG. 10. Na and Ca contents of dorrite, rhönite and its $\mathrm{Fe}^{2+}$ analogue and its $\mathrm{Ti}^{3+}$-bearing $\mathrm{Mg}$ analogue, høgtuvaite and makarochkinite. Allende rhönite containing $4.86 \mathrm{Ca}$ (Fuchs, 1971) is not plotted. Ca content includes $\mathrm{Sr}$ in the 7 analyses reported by Corsaro et al. (2007). Other information and sources are given in the caption of Fig. 9.

SFCAM (Hamilton et al., 1989, Mumme et al., 1998; Sugiyama et al., 2005) and $0.29 \mathrm{Ca}$ at $M 5$ and M6 in 'baykovite' (Arakcheeva, 1995). Al increases with $\mathrm{Ca}$ in rhönite and some dorrite (i.e. from Kauai, Hawaii, USA and Nickenicher-Sattel,
Eifel, Germany), a trend consistent with the substitution $(\mathrm{Na}, \mathrm{K})+\mathrm{Si} \rightleftharpoons \mathrm{Ca}+\mathrm{Al}$ (e.g. Kunzmann, 1989, 1999; this paper, Fig. 11). In dorrite from the type locality (Cosca et al., 1988), Buffalo, Wyoming (Foit et al., 1987) and from

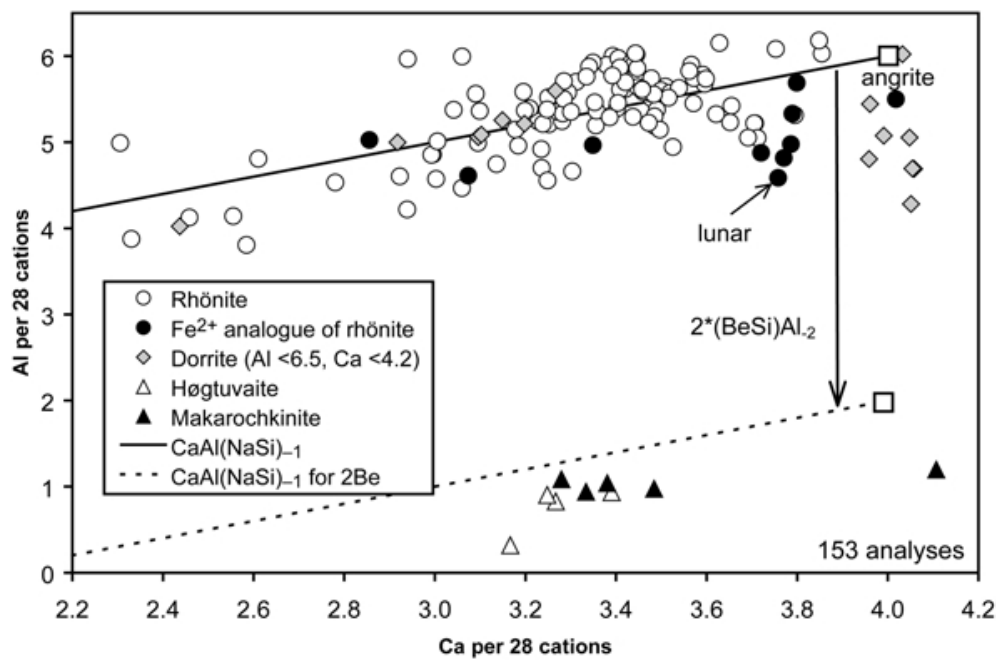

FIG. 11. $\mathrm{Al}$ and $\mathrm{Ca}$ contents of dorrite, rhönite and its $\mathrm{Fe}^{2+}$-dominant analogue, høgtuvaite and makarochkinite. Unfilled squares correspond to end-members (Table 1). Arrow shows the effect of the substitution $\mathrm{Be}+\mathrm{Si} \rightleftharpoons 2 \mathrm{Al}$. $\mathrm{Ca}$ content includes Sr in the 7 analyses reported by Corsaro et al. (2007). Other information and sources are given in the caption of Fig. 9. 
Reunion Island (Havette et al., 1982), Al does not vary with $\mathrm{Ca}$. In many of these compositions, $\mathrm{Al}$ ranges from 3 to 7 cations and $\mathrm{Si}<4$ cations per 28 cations, implying considerable $\mathrm{Al} \rightleftharpoons \mathrm{Fe}^{3+}$ substitution at tetrahedral sites as inferred by Cosca et al. (1988).

After deducting the amount equivalent to $\mathrm{Na}+$ $\mathrm{K}$, Si increases with total $\mathrm{Ti}$ from 3 atoms per 28 cations in Ti-poor dorrite to an average of about 6.3 atoms (range is 5.5-7.8) at $\mathrm{Ti}=2$ atoms (ideal rhönite) and then decreases to 4.1-5.1 atoms in the Allende rhönite (Fig. 9).

Rhönite is the only sapphirine-group mineral reported to include compositions with both $\mathrm{Mg}$ / $\left(\mathrm{Mg}+\mathrm{Fe}^{2+}\right)>0.5$ and $\mathrm{Mg} /\left(\mathrm{Mg}+\mathrm{Fe}^{2+}\right)<0.5$. Ten out of 122 rhönite compositions (excluding material in the Allende meteorite) accepted for plotting in Fig. 9 gave, after stoichiometric calculations, an excess of $\mathrm{Fe}^{2+}$ over $\mathrm{Mg}$, e.g. $\mathrm{Mg} /\left(\mathrm{Mg}+\mathrm{Fe}^{2+}\right)=0.16-0.42$ for five samples from Saint-Leu, Reunion Island (Havette et al., 1982). Meteoritic (angrite) and lunar rhönite are also clearly $\mathrm{Fe}^{2+}$-dominant with $\mathrm{Mg} /\left(\mathrm{Mg}+\mathrm{Fe}^{2+}\right)=$ 0.17 and 0.03 , respectively. The latter is the only rhönite with a normal $\mathrm{Ti}$ content $(\sim 2$ per 28 cations) to give $\mathrm{Ti}^{3+}$ when its formula is calculated on a 28 cation $/ 40$ oxygen basis (Fig. 9).

Manganese contents greater than 0.4 wt. $\%$ $\mathrm{MnO}$ have not been reported in rhönite, but up to $1.2 \mathrm{wt} \% \mathrm{MnO}$ has been found in dorrite (Nickenicher-Sattel, Eifel, Germany, Kunzmann, 1989 and pers. comm., 2007). Other constituents reported in rhönite include $\mathrm{Cr}$ (up to $3.27 \mathrm{wt} . \%$ $\mathrm{Cr}_{2} \mathrm{O}_{3}$ or $0.69 \mathrm{Cr}$ per 28 cations from basanite, Tergesh Pipe, Siberia, Timina et al., 2006) and V (up to 3.32. wt. $\% \mathrm{~V}_{2} \mathrm{O}_{3}$ or $0.69 \mathrm{~V}$ per 28 cations, Allende meteorite, Mason and Taylor, 1982). Scandium $(0.32-0.38$ wt. $\%$ oxide $)$ is also reported in rhönite from Allende (Simon et al., 1999). In contrast to aenigmatite, wilkinsonite, høgtuvaite and makarochkinite, high fieldstrength elements such as $\mathrm{Nb}$ and $\mathrm{Zr}$ have been very rarely sought in rhönite although it is likely they might substitute for Ti.

Høgtuvaite and makarochkinite are related by the substitution $\mathrm{Ti}+\mathrm{Fe}^{2+} \rightleftharpoons 2 \mathrm{Fe}^{3+}$ and form a solid solution series ranging from 0.5 to $1.3 \mathrm{Ti}$ per 28 cations (Fig. 9). Mössbauer spectroscopy suggests that $\mathrm{Fe}^{3+}$ preferentially occupies the $M 1$, $M 2$ and $M 7$ sites, and $\mathrm{Fe}^{2+}$, the $M 3-M 6$ sites; only a few per cent $\mathrm{Fe}^{3+}$ was found at tetrahedral sites in the crystal structure refinements (Grew et al., 2005). Both minerals contain $9 \mathrm{Si}$ (generally $8.5 \mathrm{Si}$ after deduction for alkalis) and $1 \mathrm{Al}$ per 28 cations, which are related to the average $\mathrm{Si}$ and $\mathrm{Al}$ contents of rhönite by the substitution $2 \mathrm{Be}+2 \mathrm{Si} \rightleftharpoons 4 \mathrm{Al}$ (Figs 9, 11). $X_{\mathrm{Mg}}=0.018-0.19$ for høgtuvaite and makarochkinite, which are significantly less magnesian than most rhönite. Phases intermediate in Be content between høgtuvaite-makarochkinite and rhönite-dorrite have not been reported. Elements reported in amounts exceeding 500 ppm in høgtuvaite and makarochkinite include $\mathrm{Zn}, \mathrm{Y}, \mathrm{Sn}, \mathrm{Nb}, \mathrm{Ta}$ and Th (Grauch et al., 1994; Grew et al., 2005).

\section{Serendibite}

The principal compositional variations in serendibite include the homovalent $\mathrm{Fe} \rightleftharpoons \mathrm{Mg}, \mathrm{Fe} \rightleftharpoons \mathrm{Al}$ substitutions, and the heterovalent $(\mathrm{Mg}, \mathrm{Fe})+\mathrm{Si} \rightleftharpoons$ 2(Al,Fe) (Tschermaks) and $\mathrm{Na}+\mathrm{Si} \rightleftharpoons \mathrm{Ca}+\mathrm{Al}$ substitutions (Grew et al., 1991a; Van Derveer et al., 1993; Grew, 1996; Aleksandrov and Troneva, 2006). In terms of mole proportions ( $\mathrm{Mg}, \mathrm{Fe}, \mathrm{Mn}) \mathrm{O}$, $(\mathrm{Al}, \mathrm{Fe})_{2} \mathrm{O}_{3}$, and $\mathrm{SiO}_{2}$, Na-poor serendibite ranges from $\mathrm{SiO}_{2}=(\mathrm{Mg}, \mathrm{Fe}, \mathrm{Mn}) \mathrm{O}=0.33$ (1:1:1 composition) to $\mathrm{SiO}_{2}=0.36$ (4:3:4 composition, which was selected as the end-member, Table 1) via the Tschermaks substitution. Compositions of $\mathrm{Na}-$ bearing serendibite (with $\mathrm{Na} /(\mathrm{Na}+\mathrm{Ca}$ ) ratio up to 0.15 ) are similar, but shifted to higher Si because of the substitution $\mathrm{Na}+\mathrm{Si} \rightleftharpoons \mathrm{Ca}+\mathrm{Al}$. Boron content ranges $2.8-3.3$ atoms per 28 cations in most analyses $(2.91-3.26 \mathrm{~B}$ in three crystal-structure refinements, Van Derveer et al., 1993), whence our selection of $3 \mathrm{~B}$ in the end-member formula. Van Derveer et al. (1993) obtained ion microprobe B contents in two samples of 3.6 and $4.2 \mathrm{~B}$ atoms per 28 cations, which they attributed to analytical error. Savel'yeva et al. (1995) reported a serendibite from the Ozyorskiy massif near Lake Baikal, Russia that is poorer in $\mathrm{Si}$ than the 1:1:1 composition and having a total of 96.69 wt.\%, suggesting a $\mathrm{B}_{2} \mathrm{O}_{3}$ content of 3-4 wt.\%, equivalent to $1.3-1.7 \mathrm{~B}$ per 28 cations or about half that in the end-member formula. Composition of the Ozyorskiy serendibite in terms of the mole proportions $(\mathrm{Mg}, \mathrm{Fe}, \mathrm{Mn}) \mathrm{O}$, $(\mathrm{Al}, \mathrm{Fe})_{2} \mathrm{O}_{3}$ and $\mathrm{SiO}_{2}$ is estimated to be 1:1.6:1 $\left(\mathrm{SiO}_{2}=0.27\right)$, i.e. midway between $4: 3: 4$ serendibite $\left(\mathrm{SiO}_{2}=0.36\right)$ and ideal dorrite $(1: 3: 1$ composition, $\mathrm{SiO}_{2}=0.2$ ). This could indicate possible miscibility between dorrite and serendibite but for the large difference between the two minerals in $\mathrm{Fe}^{3+}$ and $\mathrm{Al}$ contents calculated to occupy octahedral sites.

Possible Fe analogues constitute up to $26 \%$ of natural serendibite, whereas $\mathrm{MnO}, \mathrm{TiO}_{2}$ and other 
potential constituents do not exceed 0.5 wt. $\%$ oxide. Total $\mathrm{Fe}$ as $\mathrm{FeO}$ ranges from 0.76 to 14.75 wt. $\%$, the extremes being reported by Schmetzer et al. (2002) and Nicollet (1990), respectively. The most Fe-rich serendibite has $\mathrm{Fe}$ $>\mathrm{Mg}$, but $X_{\mathrm{Fe}^{2+}}$ could not be calculated from stoichiometry because there is no information on boron content. The maximum $X_{\mathrm{Fe}^{2+}}=0.26$ reported to date was calculated for a sample containing 13.34 wt.\% $\mathrm{Fe}$ as $\mathrm{FeO}$ from the Tayozhnoye deposit, Siberia (Grew et al., 1991a). The proportion of $\mathrm{Fe}^{3+}$ equals or exceeds $\mathrm{Fe}^{2+}$ content in most Fe-rich samples from this deposit and from the type locality (Grew et al., 1991a, Van Derveer et al., 1993). The latter authors reported no evidence for tetrahedrally coordinated $\mathrm{Fe}^{3+}$ in Tayozhnoye serendibite, and thus $\mathrm{Fe}^{3+} /\left(\mathrm{Fe}^{3+}+\mathrm{Al}\right)$ ratio at octahedral sites can be calculated from bulk $\mathrm{Fe}^{3+}$; it reaches 0.20 in these serendibite samples.

\section{Welshite}

Most welshite samples studied by Grew et al. (2007), which included the type specimen (Moore 1978) and one of the two samples analysed by Grew et al. (2001), had compositions intermediate between the end-member given in Table 1, $\mathrm{Ca}_{4}\left(\mathrm{Mg}_{9} \mathrm{Sb}_{3}^{5+}\right) \mathrm{O}_{4}\left[\mathrm{Si}_{6} \mathrm{Be}_{3} \mathrm{AlFe}_{2}^{3+} \mathrm{O}_{36}\right]$, and an Fefree equivalent, $\mathrm{Ca}_{4}\left(\mathrm{Mg}_{9} \mathrm{Sb}_{3}^{5+}\right) \mathrm{O}_{4}\left[\mathrm{Si}_{6} \mathrm{Be}_{3} \mathrm{Al}_{3} \mathrm{O}_{36}\right]$, with the first being closer to the average. The 12 tetrahedral sites in these samples (type 1) can be split into two equal subsets: (1) $\mathrm{Si}+\mathrm{As}=6$ with up to $0.6 \mathrm{As}$, and (2) $\mathrm{Al}+\mathrm{Fe}+\mathrm{Be}=6$ with $\mathrm{Be}$ ranging from 2.76 to 3.46 atoms per 28 cations and $\mathrm{Al}$, from 0.99 to 2.47 atoms. $\mathrm{Mn}$ and $\mathrm{Fe}^{3+}$ are subordinate substituents at octahedral sites. However, two samples (type 2, including the second of the two samples analysed by Grew et al., 2001) showed much greater variation related by the coupled substitution ${ }^{M} \mathrm{Sb}^{5+}+{ }^{\mathrm{vi}} \mathrm{Mg}^{2+}+$ ${ }^{\mathrm{iv}} \mathrm{Fe}^{3+} \rightleftharpoons{ }^{M} \mathrm{Fe}^{3+}+{ }^{\text {vi }} \mathrm{Fe}^{3+}+{ }^{\mathrm{iv}} \mathrm{Si}^{4+}$, where $M$ refers specifically to the $M 7, M 3 \mathrm{~A}$ and $M 4 \mathrm{~A}$ octahedral sites. This substitution relates the end-member given in Table $1, \mathrm{Ca}_{4}\left(\mathrm{Mg}_{9} \mathrm{Sb}_{3}^{5+}\right) \mathrm{O}_{4}\left[\mathrm{Si}_{6} \mathrm{Be} \mathrm{B}_{3} \mathrm{Al}\right.$ $\left.\mathrm{Fe}_{2}^{3+} \mathrm{O}_{36}\right]$, with a hypothetical $\mathrm{Sb}$-free endmember, $\mathrm{Ca}_{4}\left(\mathrm{Mg}_{6} \mathrm{Fe}_{6}^{3+}\right) \mathrm{O}_{4}\left[\mathrm{Si}_{9} \mathrm{Be}_{3} \mathrm{O}_{36}\right]$ if $\mathrm{Al}$ and $\mathrm{Fe}^{3+}$ are considered together. The lowest measured $\mathrm{Sb}$ reported by Grew et al. (2007) is 1.45 atoms per 28 cations in one compositional zone of a highly heterogeneous grain of type 2 welshite, about midway between the two end-members. A partial single-crystal refinement of a fragment from this grain found $1.64 \mathrm{Sb}$ that appears to be partially disordered at $M 7, M 3 \mathrm{~A}$ and $M 4 \mathrm{~A}$, which are fully occupied by $\mathrm{Sb}$ in type 1 welshite $(\mathrm{Sb}=3)$.

\section{Surinamite}

Surinamite compositions closely approach the ideal formula (Table 1) with $12-25 \%$ of $\mathrm{Fe}^{2+}$ substitution for $\mathrm{Mg}$ and $0-13 \%$ of $\mathrm{Fe}^{3+}$ substitution of ${ }^{\mathrm{vi}} \mathrm{Al}$ (Baba et al., 2000; Grew et al., 2000; Barbier et al., 2002). Proportions of $\mathrm{Fe}^{2+}$ and $\mathrm{Fe}^{3+}$ were calculated from stoichiometry using ideal or measured $\mathrm{Be}$ content, but in one case, $\mathrm{Fe}^{2+} / \mathrm{Fe}^{3+}$ ratio was determined by crystal structure refinement and Mössbauer spectroscopy. MnO contents do not exceed 2 wt.\%, whereas other constituents are present in amounts not exceeding a few tenths wt. $\%$, e.g. $\leqslant 0.33$ wt. $\% \mathrm{P}_{2} \mathrm{O}_{5}$ (Grew, 2002). Ion microprobe analyses of surinamite from South Harris, Scotland gave a deficiency of $0.18-0.23$ Be per 11 cations relative to the ideal formula with the charge balanced by a corresponding addition of divalent cations at the octahedral sites (Baba et al., 2000), i.e. by solid solution of $18-23 \%$ of a $\mathrm{Be}$-free analogue of surinamite, $\mathrm{Mg}_{4} \mathrm{Al}_{2} \mathrm{O}\left[\mathrm{Si}_{3} \mathrm{Al}_{2} \mathrm{O}_{15}\right]$, which Christy and Putnis (1988) suggested could also be present as one-cell wide lamellae associated with stacking faults in sapphirine from Finero, Italy.

\section{Recommended nomenclature}

\section{Introduction}

To date, recognizing distinct mineral species in the sapphirine supergroup has been ad hoc. This approach was tolerated because most members are distinct from one another in more than one compositional variable, and their recognition as distinct species did not raise a problem. However, other members, notably rhönite-dorritehøgtuvaite-makarochkinite solid solutions in which $\mathrm{Mg}, \mathrm{Fe}$ and $\mathrm{Ti}$ are the dominant cations at octahedral sites, raised nomenclature problems. There is a large number of sites with extensive cation disorder, and there are ambiguities in determining the valence of $\mathrm{Fe}$ and $\mathrm{Ti}$ from electron microprobe analyses. The crystal structures of relatively few samples have been refined (Table 2), and even crystal-structure refinements provide only broad constraints on $\mathrm{Fe}$ and $\mathrm{Ti}$ valence. For example, the distinction between makarochkinite and høgtuvaite could only be established by single crystal refinement that demonstrated that $\mathrm{Ti}$ is ordered at the $M 7$ site. Ordering of $\mathrm{Ti}$ at $M 7$ also distinguishes rhönite 
from dorrite. However, $\mathrm{Mg}$ and $\mathrm{Ti}$ are disordered in rhönite from the Allende meteorite, and $\mathrm{Ti}$ is not the dominant cation at $M 7$ (Bonaccorsi et al., 1990). Tetrahedral compositions also raise questions. For example, høgtuvaite was originally approved as a species distinct from rhönite because its Be content approached 1 atom per 20 O, i.e. Be appeared to fill one tetrahedral site. However, structure refinements show that that $\mathrm{Be}$ is split about equally between two $T$ sites in both høgtuvaite and makarochkinite, that is, one of the two makarochkinite samples studied by Grew et al. (2005) would have been called $\mathrm{Fe}^{2+}$-dominant, Be-bearing rhönite if the 50\% rule (Nickel and Grice, 1998) had been strictly applied to each of the Be-bearing tetrahedral sites.

The recommended classification (Table 4) was developed to address these problems. It makes extensive use of precedent, but applies the rules to all known natural compositions (Tables 4 and 5), with flexibility to allow for yet undiscovered compositions such as those reported in synthetic materials (Table 6). Because the sapphirine supergroup is a polysomatic series, the first level of classification is based on polysome, that is, each group within the supergroup corresponds to a single polysome. This polysomatic series consists of pyroxene (or pyroxene-like, P) and spinel (S) modules. Using the notation of Zvyagin and Merlino (2003), two polysomes have been found in nature, $<(\mathrm{P} / 2) \mathrm{S}(\mathrm{P} / 2)>$ (sapphirine group) and $<$ PSP $>$ (surinamite), where $\mathrm{P} / 2$ refers to half a pyroxene module included in an order-disorder or OD layer; $<(\mathrm{P} / 2) \mathrm{S}(\mathrm{P} / 2)>$ can be simplified to $<$ PS $>$ with a composition $M_{28} \mathrm{O}_{40}$.

The sapphirine group is divided into subgroups according to the occupancy of the two largest $M$ sites (M5 and $M 6$ in the sapphirine subgroup, $M 8$ and $M 9$ in the other subgroups), followed by division by occupancy of the smallest $M$ site (M7 in all subgroups), then by occupancies of the most polymerized $T$ sites, and lastly by $\mathrm{Mg} /\left(\mathrm{Mg}+\mathrm{Fe}^{2+}\right)$ ratio at the $M 1-M 6$ sites $(M 1-M 4, M 8-M 9$ in sapphirine). Further splitting of the supergroup based on occupancies other than those specified below is not recommended.

The only other polysome found in nature, $<$ PSP $>$ (or $<$ PPS $>$ ) has the formula $M_{22} \mathrm{O}_{32}$, and is represented by the beryllosilicate surinamite. Christy and Putnis (1988) suggested that a Befree analogue of surinamite could be present as lamellae in sapphirine, implying that subdivisions of $<$ PPS $>$ analogous to those for $<$ PS $>$ may eventually be needed in a surinamite group.

Two other polysomes $<\mathrm{SSP}>, M_{20} \mathrm{O}_{28}$ and $<$ SSPSP $>, M_{34} \mathrm{O}_{48}$ have been synthesized (Table 6), respectively, the $\mathrm{Ca}-\mathrm{Al}$ ferrites $\mathrm{CaFe}_{3} \mathrm{AlO}_{7}$ and SFCA-I (Arakcheeva et al., 1991; Mumme et al., 1998) and SFCA-II (Mumme, 2003). Examples of the $<\mathrm{P}>,<\mathrm{S}>$, $<\mathrm{PS}>, \quad<\mathrm{PPS}>$ and $<\mathrm{SSP}>$ polysomes were illustrated by Merlino and Pasero (1997).

\section{Sapphirine subgroup - a special case}

Sapphirine- $2 M$ and khmaralite are not topologically identical to sapphirine- $1 A$ and minerals in the aenigmatite and rhönite subgroups. Nonetheless, we have decided to let the similarities in chemical composition, specifically, dominance of $\mathrm{Mg}$ at the M5 and M6 sites, override the differences in crystal structure by including both polytypes of sapphirine and khmaralite in the sapphirine subgroup.

\section{First level: 〈PS〉 polysome, Sapphirine group}

\section{Second level: Two largest $M$ sites.}

Occupancy at the $M 8$ and $M 9$ sites is used to distinguish the three known subgroups, namely

TABLE 5. Examples of compositions in the sapphirine group containing substantial amounts of a potential new species, but not enough to qualify as new

\footnotetext{
Sapphirine subgroup

B analogue of sapphirine

$\mathrm{Mg}$ analogue of aenigmatite

\author{
$\mathrm{Mg}_{4}\left(\mathrm{Mg}_{3} \mathrm{Al}_{9}\right) \mathrm{O}_{4}\left[\mathrm{Si}_{3} \mathrm{~B}_{2} \mathrm{Al}_{7} \mathrm{O}_{36}\right]$ \\ Aenigmatite subgroup \\ $\mathrm{Na}_{4}\left(\mathrm{Mg}_{10} \mathrm{Ti}_{2}\right) \mathrm{O}_{4}\left[\mathrm{Si}_{12} \mathrm{O}_{36}\right]$
}

Grew et al. $(1990,1991 b, 1992)$ up to $25 \%$ of the B analogue

Price et al. (1985 and unpublished data) reported $\mathrm{Mg} /\left(\mathrm{Mg}+\mathrm{Fe}^{2+}\right)$ up to 0.48
} 
TABLE 6. Compounds related to the sapphirine supergroup, either synthetic or not strictly natural.

Sapphirine subgroup $\mathrm{Cr}$ dominant analogue of sapphirine (synthetic) $\mathrm{Ga}, \mathrm{Ge}$ analogues of sapphirine- $1 A$ (synthetic) $P \overline{1}$

Aenigmatite subgroup Synthetic $P \overline{1}$

Synthetic $P \overline{1}$ Synthetic $P \overline{1}$ Synthetic $P \overline{1}$

Rhönite subgroup:

'Baykovite' (synthetic) $P \overline{1}$

'Leucorhönite'*

'Malakhovite'*

(cf. SFCA)

SFCA

(synthetic) $P \overline{1}$

SFCAM

(synthetic) $P \overline{1}$

CSVA

(synthetic) $P \overline{1}$

$\mathrm{Al}, \mathrm{Ge}$ analogue of surinamite (synthetic) $C 2 / c$ and $P 2 / n$

$\mathrm{Ga}$, Ge analogue of surinamite (synthetic) $C 2 / c$

Synthetic ferrite

$P \overline{1}$

SFCA-I

(synthetic) $P \overline{1}$

SFCA-II

(synthetic $P \overline{1}$ )

\section{Sapphirine group: $<$ PS $>$ Polysome}

$$
\begin{aligned}
& \mathrm{Mg}_{4}\left(\mathrm{Mg}_{3.8} \mathrm{Cr}_{6.7} \mathrm{Al}_{1.4}\right) \mathrm{O}_{4}\left[\mathrm{Si}_{4.2} \mathrm{Al}_{7.8} \mathrm{O}_{36}\right] \\
& \mathrm{Mg}_{4}\left(\mathrm{Mg}_{2} \mathrm{Ga}_{10}\right) \mathrm{O}_{4}\left[\mathrm{Ge}_{2} \mathrm{Ga}_{10} \mathrm{O}_{36}\right](3: 5: 1) \text { to } \\
& \mathrm{Mg}_{4}\left(\mathrm{Mg}_{8} \mathrm{Ga}_{4}\right) \mathrm{O}_{4}\left[\mathrm{Ge}_{8} \mathrm{Ga}_{4} \mathrm{O}_{36}\right](3: 1: 2)
\end{aligned}
$$

Brigida et al. (2007)

Barbier (1990, 1998)

$$
\begin{aligned}
& \mathrm{Na}_{4}\left(\mathrm{Mg}_{8.5} \mathrm{Fe}_{3}^{3+} \mathrm{Si}_{0.5}\right) \mathrm{O}_{4}\left[\mathrm{Si}_{12} \mathrm{O}_{36}\right] \text { to } \\
& \mathrm{Na}_{4}\left(\mathrm{Mg}_{9} \mathrm{Fe}_{2}^{3+} \mathrm{Si}\right) \mathrm{O}_{4}\left[\mathrm{Si}_{12} \mathrm{O}_{36}\right] \\
& \mathrm{Na}_{4} \mathrm{Mg}_{12}(\mathrm{OH})_{4}\left[\mathrm{Si}_{12} \mathrm{O}_{36}\right] \\
& \mathrm{Na}_{4} \mathrm{Mg}_{7.2} \mathrm{Fe}_{4.8}^{3+} \mathrm{O}_{4}\left[\mathrm{Ge}_{11.2} \mathrm{Fe}_{0.8}^{3+} \mathrm{O}_{36}\right] \\
& \mathrm{Na}_{4}\left(\mathrm{Na}_{1.48} \mathrm{Mn}_{5.54}^{2+} \mathrm{Mn}_{4.98}^{3+}\right) \mathrm{O}_{4}\left[\mathrm{Ge}_{12} \mathrm{O}_{36}\right]
\end{aligned}
$$

Gasparik et al. (1999)

Yang and Konzett (2000)

Barbier (1995)

Redhammer et al. (2008)

$$
\mathrm{Ca}_{4}\left(\mathrm{Ca}_{0.3} \mathrm{Mg}_{5.55} \mathrm{Al}_{0.24} \mathrm{Ti}_{3.69}^{3+} \mathrm{Ti}_{2.23}^{4+}\right) \mathrm{O}_{4}\left[\mathrm{Si}_{3.6} \mathrm{Al}_{8.4} \mathrm{O}_{36}\right]
$$

$\mathrm{Ca}_{4}\left(\mathrm{Ca}_{0.4} \mathrm{Mg}_{6.8} \mathrm{Fe}_{1.1}^{2+} \mathrm{Fe}_{2.1}^{3+} \mathrm{Al}_{1.5} \mathrm{Ti}_{0.1}\right) \mathrm{O}_{4}\left[\mathrm{Si}_{8.3} \mathrm{Al}_{3.7} \mathrm{O}_{36}\right]$ $\mathrm{Ca}_{4}\left(\mathrm{Ca}_{0.7} \mathrm{Mg}_{1.3} \mathrm{Fe}_{0.7}^{2+} \mathrm{Fe}_{9.2}^{3+} \mathrm{Ti}_{0.1}\right) \mathrm{O}_{4}\left[\mathrm{Si}_{2.6} \mathrm{Al}_{2.6} \mathrm{Fe}_{6.8}^{3+} \mathrm{O}_{36}\right]$

$\mathrm{Ca}_{4}\left(\mathrm{Ca}_{0.6} \mathrm{Mg}_{1.6} \mathrm{Fe}_{9.8}^{3+}\right) \mathrm{O}_{4}\left[\mathrm{Si}_{2.2} \mathrm{Al}_{3.0} \mathrm{Fe}_{6.8}^{3+} \mathrm{O}_{36}\right]^{\dagger}$

$\mathrm{Ca}_{4}(\mathrm{Ca}, \mathrm{Fe}, \mathrm{Mg}, \mathrm{Al})_{12} \mathrm{O}_{4}\left[(\mathrm{Fe}, \mathrm{Al}, \mathrm{Si})_{12} \mathrm{O}_{36}\right]$

$\mathrm{Ca}_{4}\left(\mathrm{Mn}_{0.024} \mathrm{Fe}_{0.026} \mathrm{Mg}_{1} \mathrm{Al}_{5.5} \mathrm{Ti}_{0.3} \mathrm{~V}_{5.15}\right) \mathrm{O}_{4}\left[\mathrm{Si}_{2.36} \mathrm{Al}_{9.64} \mathrm{O}_{36}\right]$

Surinamite group: <PPS $>$ Polysome

$\mathrm{Mg}_{4} \mathrm{Al}_{2} \mathrm{O}\left[\mathrm{Ge}_{3} \mathrm{Al}_{2} \mathrm{O}_{15}\right]$

Rudneva and Malysheva, 1960);

Arakcheeva (1995)

Chesnokov et al. (1994)

Chesnokov et al. (1993)

Mumme et al. (1988);

Hamilton et al. (1989)

Sugiyama et al. (2005)

Arakcheeva and Ivanov (1993)

$$
\mathrm{Mg}_{4} \mathrm{Ga}_{2} \mathrm{O}\left[\mathrm{Ge}_{3} \mathrm{Ga}_{2} \mathrm{O}_{15}\right]
$$

Barbier (1996, 1998)

Barbier (1996)

Arakcheeva et al. (1991)

Mumme et al. (1998)

$\mathrm{Ca}_{3.18} \mathrm{Fe}_{0.82}^{2+} \mathrm{Fe}_{14.66}^{3+} \mathrm{Al}_{1.34} \mathrm{O}_{28}$

$$
<\text { SSPSP }>\text { Polysome }
$$

$\mathrm{Ca}_{5.1} \mathrm{Fe}_{0.9}^{2+} \mathrm{Fe}_{18.7}^{3+} \mathrm{Al}_{9.3} \mathrm{O}_{48}$

\footnotetext{
* Combustion products found in waste dumps of coal mines in the Chelyabinsk basin. These products are considered to be substances formed by human intervention, and thus are not minerals (Nickel and Grice, 1998).

${ }^{\dagger}$ Formula is written assuming $\mathrm{Al}$ is all tetrahedrally coordinated, but an undetermined amount might be octahedrally coordinated (Hamilton et al., 1989).
} 
sapphirine $(\mathrm{Mg})$, aenigmatite $(\mathrm{Na})$, and rhönite $(\mathrm{Ca})$; the corresponding sites in sapphirine- $1 A$ are $M 5$ and M6 (Tables 2 and 3). $\mathrm{Na}$ and $\mathrm{Ca}$ at these two sites are largely disordered, so that the two sites can be considered as a unit in distinguishing the aenigmatite and rhönite subgroups. Na content (cut off at $2 \mathrm{Na}$ per 28 cations) is the most readily applied measure. Calcium could also occupy the M5 and M6 sites, which has been reported in synthetic compounds (Hamilton et al., 1989; Arakcheeva, 1995; Sugiyama et al., 2005). In solid solutions between serendibite and sapphirine- $1 A$, i.e. Ca- and B-bearing sapphirine (Grew et al., 1992), Ca, $\mathrm{Na}$ and $\mathrm{Mg}$ presumably occupy the M5 and M6 sites, but it is not known whether there is any ordering. The report of a Fe$\mathrm{Sn}-\mathrm{Ga}-\mathrm{Ge}$ phase possibly isostructural with sapphirine (Johan and Oudin, 1986) suggests the possibility of a $\mathrm{Fe}^{2+}$-dominant subgroup. No mineral approaches an Mn-dominant subgroup: the maximum reported is $0.2 \mathrm{Mn}$ at $M 8$ and $M 9$ in makarochkinite, i.e. 5\% occupancy at each site (Grew et al., 2005).

\section{Third level: $M 7$ site}

Occupancy at the $M 7$ site is used to distinguish species within the aenigmatite subgroup and species or clusters of species within the rhönite subgroup; Al is dominant in both species of the sapphirine subgroup. In most cases, smaller, more highly charged cations, principally $\mathrm{Al}$ (sapphirine, serendibite), $\mathrm{Ti}^{4+}$ (aenigmatite, rhönite, makarochkinite), $\mathrm{Cr}^{3+}$ (krinovite), and $\mathrm{Nb}^{5+}$ are ordered at $M 7 . \mathrm{Fe}^{3+}$ is the dominant cation at $M 7$ in høgtuvaite and wilkinsonite (Grew et al., 2005; Burt et al., 2007), and presumably also in dorrite by analogy with similar synthetic compounds (Hamilton et al, 1989; Mumme et al., 1998; Sugiyama et al., 2005). Figure $7 a$ illustrates the substitution ${ }^{\mathrm{vi}} \mathrm{Ti}+{ }^{\mathrm{vi}} \mathrm{Fe}^{2+} \rightleftharpoons 2^{\mathrm{vi}} \mathrm{Fe}^{3+}$ relating aenigmatite and wilkinsonite. Rhönite-like minerals but with $\mathrm{Ti}<1$ per 28 cations are dorrite (Fig. 9), e.g. 'rhönite' from Kauai, Hawaii, USA (Johnston and Stout, 1984) and NickenicherSattel (alternative name, Eicher Sattel), Eifel, Germany (Kunzmann, 1989 and pers. comm., 2007; Rondorf, 1989). In addition, Cosca et al. (1988) recognized an unknown $\left(\mathrm{X}_{1}\right.$, Havette et al., 1982) and $\mathrm{Fe}^{3+}$-rich melilite (Foit et al., 1987) as dorrite.

Welshite and Allende rhönite are distinct from the others in that $\mathrm{Mg}$ and $\mathrm{Sb}^{5+}$ or $\mathrm{Ti}$ are present in roughly equal amounts at $M 7$, but the ordering in these two phases differs. Welshite lacks a centre of symmetry and the $M 7$ site is split into two sites. In the sample for which a refinement is available, $M 7$ and M7A are fully occupied by $\mathrm{Sb}$ and $\mathrm{Mg}$, respectively, i.e. ordering of $\mathrm{Sb}$ and $\mathrm{Mg}$ is complete within the error of the refinement. The presence of welshite containing only $1.45 \mathrm{Sb}$ per 28 cations (vs. 3 in the ideal formula) and $3.44 \mathrm{Fe}^{3+}$ at octahedral sites suggests the possibility of a $\mathrm{Fe}^{3+}$-dominant analogue of welshite with $\mathrm{Fe}^{3+}>(\mathrm{Sb}+\mathrm{Mg})$ at $M 7$ and $M 7 \mathrm{~A}$, but this could not be demonstrated by single-crystal refinement (Grew et al., 2007). In contrast, $\mathrm{Ti}$ is not ordered at $M 7$ in rhönite from the Allende meteorite. Bonaccorsi et al. (1990) refined the occupancy at $M 7$ in a crystal from Allende to be $44 \% \mathrm{Ti}, 56 \%$ $\mathrm{Mg}$ and gave a formula for the analysed crystal as ${ }_{M 8, M 9}\left(\mathrm{Ca}_{4}\right)^{M 5, M 6}\left(\mathrm{Mg}_{3.4} \mathrm{Fe}_{0.6}^{2+}\right)^{M 1-M 4, M 7}\left(\mathrm{Mg}_{2.4} \mathrm{Al}\right.$ $\left.\mathrm{V}_{0.6} \mathrm{Ti}_{1.6}^{3+} \mathrm{Ti}_{2.4}^{4+}\right) \mathrm{O}_{4}\left[\mathrm{Si}_{4} \mathrm{Al}_{8} \mathrm{O}_{36}\right]$. Thus, the Allende rhönite does not qualify either as rhönite $\left(\mathrm{Ti}^{4+}\right.$ dominant at $M 7)$ or dorrite $\left(\mathrm{Fe}^{3+}\right.$-dominant at $\left.M 7\right)$. We suggest that Allende rhönite be considered a distinct species with $\mathrm{Mg}$ dominant at $M 7$.

Although ${ }^{\mathrm{vi}} \mathrm{Fe}^{3+} /\left({ }^{\mathrm{vi}} \mathrm{Fe}^{3+}+{ }^{\mathrm{vi}} \mathrm{Al}\right)$ ratio reaches 0.20 in a serendibite from the Tayozhnoye deposit (see above), $\mathrm{Fe}^{3+} /\left(\mathrm{Fe}^{3+}+\mathrm{Al}\right)=0.091$ at $M 7$ in this sample (5152, Van Derveer et al., 1993), i.e. this sample contains only $9 \%$ of the $\mathrm{Fe}^{3+}$ analogue of serendibite.

Gasparik et al. (1999) synthesized Mg-analogues of wilkinsonite with $\mathrm{Si}>12$ atoms per 28 cations at $13-14 \mathrm{GPa}$ and $1450-1700^{\circ} \mathrm{C}$, i.e. $\mathrm{Si}$ occupies octahedral sites. One refinement gave $0.806(\mathrm{Mg}, \mathrm{Si})+0.194 \mathrm{Fe}^{3+}$ at $M 7$ and a relatively short $<M 7-\mathrm{O}>$ of $1.981 \AA$, which suggests that $\mathrm{Si}$ could a major constituent at this site, but leaves open the question whether it is the most abundant.

\section{Fourth level: Most polymerized Tsites}

Occupancy at the $T 2$ and $T 3$ sites in the sapphirine subgroup ( $T 1$ and $T 4$ in the other subgroups), which are the most polymerized in the sapphirine group $\left(\mathrm{Q}^{3}\right.$ in the terminology of Christy et al., 1992), is used to distinguish species within clusters defined by $M 7$ occupancy. Following Grew et al. (2005), we recommend considering the two $\mathrm{Q}^{3}$ sites together. These two sites are occupied by $\mathrm{Si}$ or by $\mathrm{Si}$ and $\mathrm{Al}$ in roughly equal amounts in the aenigmatite subgroup and rhönite. Si dominance at the two sites was inferred for the relatively $\mathrm{Mg}$ - and Si-rich dorrite-like synthetic ferrite, SFCAM (Sugiyama et al., 2005), whereas in SFCA containing less $\mathrm{Si}$ and little or no $\mathrm{Mg}, \mathrm{Si}$ is dominant at $T 4$ but absent at T1 (Hamilton et al., 1989; Mumme et 
al., 1998). Only $\mathrm{Al}$ is reported at the two $\mathrm{Q}^{3}$ sites in Si-free ferrite (Mumme, 2003). In the three sapphirines for which crystal structures are available (Moore, 1969; Higgins and Ribbe, 1979; Merlino, 1980), $\mathrm{Si}$ is the dominant cation at these two sites (Tables 2 and 3), an occupancy that Christy et al. (1992) attributed to preference for $\mathrm{Si}-\mathrm{O}-\mathrm{Al}$ bridges. $\mathrm{Al}$ would be the dominant cation at these two $T$ sites in sapphirine containing less than $2 \mathrm{Si}$ per 28 cations (Fig. 6), i.e. less $\mathrm{Si}$ than the composition $\mathrm{Mg}_{6} \mathrm{Al}_{10} \mathrm{O}_{4}\left[\mathrm{Si}_{2} \mathrm{Al}_{10} \mathrm{O}_{36}\right]$. Such sapphirine would be a distinct species, the Al-dominant analogue. Sabau et al. (2002) reported a sapphirine with $1.709 \mathrm{Si}$ per 28 cations, which is the only composition we found that would qualify as an Al-dominant analogue of sapphirine. According to Christy et al. (1992), sapphirine compositions with $\mathrm{Si}<2$ appear to be unstable relative to spinel-bearing assemblages, and thus this species is expected to be rare.

In høgtuvaite, makarochkinite, serendibite and khmaralite, Be and B are markedly ordered at both sites relative to the other $T$ sites. Linkage between T1 and T4 (rhönite subgroup) precludes the presence of significantly more than $50 \%$ Be at both sites simultaneously in relatively disordered structures, e.g. respectively, $44-48 \%$ and $46-52 \%$ in makarochkinite and, respectively, $50 \%$ and $51 \%$ in høgtuvaite as $\mathrm{Be}-\mathrm{O}-\mathrm{Be}$ bridges would result in underbonding of the bridging O (Christy et al., 2002; Grew et al., 2005). If the two sites are considered together, the Be content in end-member formulae is 2 per 28 cations, equivalent to filling one tetrahedral site. In more ordered structures, occupancy reaches $100 \% \mathrm{Be}$ (welshite) and $70 \% \mathrm{Be}$ (khmaralite), so the $50 \%$ rule could be applied to one site. Nonetheless, we would prefer to have a criterion based on bulk chemistry that would be applicable to all sapphirine-group minerals. Khmaralite was distinguished from sapphirine by both the presence of a superstructure (doubled chain periodicity) and Be ordering (Barbier et al. 1999), but in the present nomenclature, the critical distinction is $\mathrm{Be}>1$ atom per 28 cations in khmaralite, which is roughly coincident with appearance of the superstructure (Grew et al., 2000). Christy et al. (2002) described a synthetic beryllian sapphirine containing up to $2 \mathrm{Be}$ per 28 cations, e.g. $\mathrm{Mg}_{4}\left(\mathrm{Mg}_{4} \mathrm{Al}_{8}\right) \mathrm{O}_{4}\left[\mathrm{Al}_{4} \mathrm{Be}_{2} \mathrm{Si}_{6} \mathrm{O}_{36}\right]$, but lacking the superstructure characteristic of khmaralite. The synthetic sapphirine is dominantly the $1 A$ polytype with lamellae of the $2 M$ polytype. In principle, if such a sapphirine were found naturally, it would be a species distinct from khmaralite because it would lack the superstructure characteristic of khmaralite.

$\mathrm{By}$ analogy with $\mathrm{Be}$, we group the sites for $\mathrm{B}$, although $\mathrm{B}-\mathrm{O}-\mathrm{B}$ bridges are tolerated in serendibite, and B occupancy at $T 1$ and $T 4$ can simultaneously exceed $50 \%$ by a significant amount, reaching $65 \%$ and $98 \%$, respectively, in serendibite (Van Derveer et al., 1993). The possibility of a B-dominant analogue of sapphirine is suggested by the average composition reported by Grew et al. (1992) from Johnsburg, New York. The B content of the average (0.84 B per 28 cations) corresponds to $10 \%$ serendibite and $25 \%$ of a B-analogue of sapphirine, $\mathrm{Mg}_{4}\left(\mathrm{Mg}_{3} \mathrm{Al}_{9}\right) \mathrm{O}_{4}\left[\mathrm{Si}_{3} \mathrm{~B}_{2} \mathrm{Al}_{7} \mathrm{O}_{36}\right]$ (Table 1). Although $25 \%$ is not sufficient to define a new species, study of the Johnsburg sample at higher resolution than was possible by Grew et al. (1992) might reveal patches containing more of the $\mathrm{Mg}_{4}\left(\mathrm{Mg}_{3} \mathrm{Al}_{9}\right) \mathrm{O}_{4}$ $\left[\mathrm{Si}_{3} \mathrm{~B}_{2} \mathrm{Al}_{7} \mathrm{O}_{36}\right]$ end-member than of either of the serendibite or B-free sapphirine end-members, and thereby qualify as a new B-dominant analogue of sapphirine distinct from serendibite. TEM study indicates that the sapphirine grains are uniformly sapphirine- $1 A$ despite their chemical heterogeneity (Grew et al., 1992).

$\mathrm{Ge}$ and $\mathrm{Ga}$ are potential substituents at the $T 2(T 4)$ and $T 3(T 1)$ sites. There is a Fe-Sn-Ga-Ge mineral possibly isostructural with sapphirine (Johan and Oudin, 1986) and several synthetic compounds (Table 6), i.e. a Mg- and Ge-analogue of wilkinsonite (Barbier, 1995) and Ga- and Ge analogues of sapphirine-1 $A$ with $\mathrm{MgO}: \mathrm{Ga}_{2} \mathrm{O}_{3}: \mathrm{GeO}_{2}$ ratios ranging from 3:5:1 almost to 3:1:2 (Barbier, 1990; 1998). A Na$\mathrm{Mn}^{2+}-\mathrm{Mn}^{3+}$ germanate isostructural with aenigmatite has been synthesized without any Ga (Redhammer et al., 2008).

Fifth level: $\mathrm{Mg} /\left(\mathrm{Mg}+\mathrm{Fe}^{2+}\right)$ ratio

A final criterion is $\mathrm{Mg} /\left(\mathrm{Mg}+\mathrm{Fe}^{2+}\right)=X_{\mathrm{Mg}}$ ratio at $M 1-M 6$ sites $(M 1-M 4, M 8-M 9$ in sapphirine). With rare exception, each mineral listed in Table 1 has been found to be either Mgdominant, i.e. $X_{\mathrm{Mg}}>0.5$, or $\mathrm{Fe}^{2+}$-dominant, i.e. $X_{\mathrm{Mg}}<0.5$, at these $M$ sites. However, $X_{\mathrm{Mg}}$ ranges from 1.00 to 0.03 in material described as rhönite. In this case, the 10 analyses giving $X_{\mathrm{Mg}}<0.5$ correspond to the $\mathrm{Fe}^{2+}$-dominant analogue, which is a distinct species (Table 4). The most magnesian wilkinsonite $\left(X_{\mathrm{Mg}}=0.53\right)$ is poten- 
tially a distinct species, and the most magnesian aenigmatite reported to date, $X_{\mathrm{Mg}}=0.48$ (Table 5), suggests the possibility of finding the Mg-dominant analogue of aenigmatite, which would also be a distinct species.

According to Hatert and Burke (2008), this criterion could be expanded to include other divalent cations at the $M 1-M 6$ sites $(M 1-M 4$, $M 8-M 9$ in sapphirine) resulting in ternary and higher order solid solutions, e.g. Mn, which is a significant, albeit subordinate, constituent at these sites in welshite, but is minor in other sapphirinegroup minerals.

\section{Other criteria}

Further breakdown is possible because larger octahedral cations tend to be ordered at the M5 and M6 sites and larger tetrahedral cations at the $T 5$ and T6 sites. However, in many cases occupancies at these sites are correlated with occupancies at the sites used to distinguish the different species, e.g. Fe ordering at $M$ sites is correlated with presence of $\mathrm{Be}$ in khmaralite (Barbier et al., 1999). Grew et al. (2007) suggested the possibility of splitting out species in welshite based on the dominance of $\mathrm{Fe}^{3+}$ and $\mathrm{Al}$ at $T 5$ and T6A. However, in one sample, tetrahedral $\mathrm{Fe}^{3+}$ content is correlated with $\mathrm{Sb}$ content. Tetrahedral $\mathrm{Fe}^{3+}$ content in dorrite from the type locality is calculated to range from 0.4 to 5.5 atoms per 28 cations (Cosca et al., 1988), suggesting the possibility of $\mathrm{Fe}^{3+}$ dominance at $T 5$ and $T 6$ in some samples but $\mathrm{Al}$ dominance in others, i.e. two species could be split out on the basis of $T 5$ and $T 6$ occupancy. However, further splitting would result in a needless proliferation of species, and is not consistent with earlier decisions by the CNMNC on sapphirine-group minerals.

A special case is $\mathrm{OH}$. Minerals of the sapphirine group are presumed to be anhydrous, and crystal structure refinements show no evidence for the presence of $\mathrm{OH}$ in natural material. However, an $\mathrm{OH}$-bearing, Ti-free $\mathrm{Mg}$ analogue of aenigmatite has been synthesized at $10 \mathrm{GPa}$ and $1250^{\circ} \mathrm{C}$ (Yang and Konzett, 2000), suggesting the possibility of $\mathrm{OH}$ incorporation at high pressure.

\section{First level: 〈PPS〉 polysome, surinamite group}

This group contains only one natural member that is found as an independent phase, surinamite, and the designation of group anticipates discovery of other members. Christy and Putnis (1988) suggested that lamellae associated with stacking faults in sapphirine from Finero, Italy could be a Be-free analogue of surinamite. By analogy with the sapphirine group, the criterion for distinguishing the Be-free analogue would be occupancy of $\mathrm{Al}$ or $\mathrm{Si}$ instead of $\mathrm{Be}$ at the $T 1$ site. Barbier (1996, 1998) synthesized Ge- and Gaanalogues of Be-free surinamite in one of which Ga and Ge occupy the $T 1$ site (Table 6).

\section{Possible new names and species}

The new nomenclature does not result in new names for existing species. Names in current usage (Tables 1, 4) remain unchanged. However, new names would be required for the compositions that we suggest are sufficiently distinct to be recognized as new species in the above section outlining our nomenclature. It would be premature for us to propose specific names here, but only to summarize the compositional features indicating that the minerals in question are distinct from recognized species.

\section{Unnamed Al-analogue of sapphirine}

Sabau et al. (2002) reported a peraluminous sapphirine from the South Carpathians, Romania, for which the calculated formula contained only $1.71 \mathrm{Si}$ per 28 cations, i.e. less Si than the composition $\mathrm{Mg}_{6} \mathrm{Al}_{10} \mathrm{O}_{4}\left[\mathrm{Si}_{2} \mathrm{Al}_{10} \mathrm{O}_{36}\right]$ (Fig. 6). In such a sapphirine, Al would be the dominant cation at the $T 2$ and $T 3$ sites, i.e. the Aldominant analogue of sapphirine.

\section{Unnamed Mg-analogue of wilkinsonite}

Recalculation of the analysis of wilkinsonite in a syenitic ejectum from the inner caldera of the Wonchi volcano, Ethiopia (Gaeta and Mottana, 1991) gave $X_{\mathrm{Mg}}\left(\right.$ as $\mathrm{Mg} /\left(\mathrm{Mg}+\mathrm{Fe}^{2+} \mathrm{Mn}+\mathrm{Ni}\right)=$ $0.47, X_{\mathrm{Fe}^{2+}}=0.42, X_{\mathrm{Mn}}=0.10$ and $X_{\mathrm{Ni}}=0.01$, i.e. $\mathrm{Mg}$ is the dominant divalent cation presumed to occupy the $M 1-M 6$ sites. In principle the mineral would be a new species because of the rule of the dominant constituent for homovalent ternary solid solutions (Hatert and Burke, 2008). However, given the relatively small excess of $\mathrm{Mg}$ over $\mathrm{Fe}^{2+}$ and the large error in calculating $\mathrm{Fe}^{3+} / \mathrm{Fe}^{2+}$ ratio from stoichiometry, its species status is less certain than that for nearly end-member $\mathrm{Fe}^{2+}$ - analogue of rhönite (see below). The formula calculated for the Wonchi wilkinsonite implies that not only is there significantly more octahedral $\mathrm{Fe}^{3+}$ and less total 
divalent cations than in other wilkinsonite, but also significant $\mathrm{Fe}^{3+}$ is substituting for $\mathrm{Si}$ at tetrahedral sites (the composition cannot be plotted in Fig. 7), whence the different formula given for a possible $\mathrm{Mg}$ analogue in Table 1.

\section{Unnamed $\mathrm{Fe}^{2+}$-analogue of rhönite}

Recalculation of analyses of rhönite from (1) phonolitic differentiate, Puy de SaintSandoux, Auvergne, France (Grünhagen and Seck, 1972), (2) coral penetrated by basalt at Saint-Leu, Reunion Island (Havette et al., 1982), (3) basanite, Scania, Sweden (Olsson, 1983) and (4) a spinel-wehrlite xenolith from Foster Crater, McMurdo Volcanic Group, Antarctica (Gamble and Kyle, 1987) gave $\mathrm{Mg} /\left(\mathrm{Mg}+\mathrm{Fe}^{2+}\right)=$ $0.156-0.499$. In addition, $\mathrm{Mg} /\left(\mathrm{Mg}+\mathrm{Fe}^{2+}\right)=$ 0.17 and 0.03 in rhönite from angrite Northwest Africa 4590 (Kuehner and Irving, 2007) and the Luna 24 regolith (Treiman, 2008), respectively, and identity of the analysed grain in Luna 24 as rhönite was confirmed by Raman spectroscopy. Even allowing for the large uncertainty in the calculation based on stoichiometry, we conclude that most of these rhönite samples are clearly $\mathrm{Fe}^{2+}$-dominant and distinct from other rhönite, i.e. they are the $\mathrm{Fe}^{2+}$-dominant analogue. Many of the compositions are also distinct in other ways, e.g. the Reunion Island rhönite contains more Ti than most (2.43-3.00 Ti per 28 cations, Fig. 9). Trivalent cations at the $M$ sites in this and the angrite rhönite are calculated to total $0-1.5$ per 28 cations, less than in the end-member formula for rhönite. Our proposed end-formula for the unnamed Fe-analogue of rhönite (Table 1) approximates Treiman's (2008) formula of the lunar rhönite, although its composition differs in its high $\mathrm{Si}$ and low $\mathrm{Al}$ contents from other rhönite (Figs 9, 11)

\section{Unnamed $\mathrm{Ti}^{3+}$-bearing $\mathrm{Mg}$-analogue of rhönite}

Rhönite that is associated with melilite, 'fassaite', spinel and perovskite in inclusions in the Allende meteorite contains 3.20 to 4.57 Ti per 28 cations (Fuchs, 1971, 1978; Mao and Bell, 1974; Mason and Taylor, 1982; Simon et al., 1999) and the calculated proportion of $\mathrm{Ti}^{3+}$ increases with total $\mathrm{Ti}$ (Fig. 9). $\mathrm{Ti}$ is not ordered at $M 7$; instead, $\mathrm{Mg}$ is dominant at this site (Bonaccorsi et al., 1990), an M7 occupancy that distinguishes the Allende mineral from both rhönite $\left(\mathrm{Ti}^{4+}\right.$-dominant) and dorrite $\left(\mathrm{Fe}^{3+}\right.$-dominant). A salient feature of the
Allende mineral is the identity of the most abundant octahedrally coordinated trivalent cation: $\mathrm{Ti}^{3+} v s . \mathrm{Fe}^{3+}$ in rhönite and its $\mathrm{Fe}^{2+}$ analogue (except one), whence the rationale for calling the Allende mineral an unnamed $\mathrm{Ti}^{3+}$ bearing $\mathrm{Mg}$-analogue of rhönite.

\section{Unnamed Fe-Sn-Ga-Ge mineral}

Johan and Oudin (1986) reported a Fe-Sn-Ga-Ge mineral in grains about $15 \mu \mathrm{m}$ across in sphalerite from Montauban, Haute Garonne, France. The grains have pseudohexagonal outlines. In calculating formulae from electron microprobe analyses, Johan and Oudin (1986) reported that assuming 7 cations and 10 oxygens gave a better stoichiometry (e.g. Table 7) than assuming 3 cations and 4 oxygens (spinel stoichiometry); our attempt to calculate a formula assuming 3 cations and 4 oxygens from the six published analyses gave negative $\mathrm{Fe}^{3+}$ contents (from 10 to 12 wt. $\% \mathrm{Fe}_{2} \mathrm{O}_{3}$ ). It is thus unlikely the mineral is a spinel, and we concur with the conclusion

TABLE 7. Selected compositions of unnamed Fe-SnGa-Ge mineral (from Johan and Oudin, 1986)

\begin{tabular}{|c|c|c|}
\hline Analysis & 3 & 6 \\
\hline & \multicolumn{2}{|c|}{ Wt. $\%$} \\
\hline $\mathrm{GeO}_{2}$ & 8.68 & 5.07 \\
\hline $\mathrm{SnO}_{2}$ & 14.63 & 13.12 \\
\hline $\mathrm{Fe}_{2} \mathrm{O}_{3}$ & 5.97 & 4.34 \\
\hline $\mathrm{Ga}_{2} \mathrm{O}_{3}$ & 45.94 & 55.33 \\
\hline $\mathrm{MnO}$ & 0.74 & 0.85 \\
\hline $\mathrm{FeO}$ & 19.79 & 15.90 \\
\hline $\mathrm{ZnO}$ & 3.93 & 4.46 \\
\hline \multirow[t]{2}{*}{ Sum } & 99.68 & 99.07 \\
\hline & \multicolumn{2}{|c|}{ Formulae } \\
\hline $\mathrm{Ge}$ & 2.153 & 1.270 \\
\hline${ }^{\mathrm{iv}} \mathrm{Ga}$ & 9.847 & 10.730 \\
\hline Sum $T$ & 12.000 & 12.000 \\
\hline $\mathrm{Sn}$ & 2.518 & 2.281 \\
\hline${ }^{\mathrm{vi}} \mathrm{Ga}$ & 2.869 & 4.741 \\
\hline $\mathrm{Fe}^{3+}$ & 1.941 & 1.426 \\
\hline $\mathrm{Zn}$ & 1.253 & 1.436 \\
\hline $\mathrm{Mn}$ & 0.271 & 0.314 \\
\hline $\mathrm{Fe}^{2+}$ & 7.148 & 5.801 \\
\hline Sum $M$ & 16.000 & 15.999 \\
\hline
\end{tabular}

Electron microprobe analyses. Formula and $\mathrm{Fe}^{3+} / \mathrm{Fe}^{2+}$ ratio calculated assuming 28 cations and 40 oxygens. 
reached by Johan and Oudin (1986) that the mineral could be related to sapphirine. Nonetheless, XRD data will be needed to confirm the relationship. The analysed grains range in $\mathrm{Ga}_{2} \mathrm{O}_{3}$ content from 45.9 to $55.3 \mathrm{wt} . \%$ (e.g. Table 7) and the most important substitution appears to be ${ }^{\mathrm{iv}} \mathrm{Ge}+{ }^{\mathrm{vi}} \mathrm{Fe}^{2+} \rightleftharpoons{ }^{\mathrm{iv}} \mathrm{Ga}+{ }^{\mathrm{vi}} \mathrm{Ga}$, but substitutions such as ${ }^{\mathrm{vi}} \mathrm{Sn}+{ }^{\mathrm{vi}} \mathrm{Fe}^{2+} \rightleftharpoons 2^{\mathrm{vi}} \mathrm{Ga}$ and $\mathrm{Fe}^{3+} \rightleftharpoons \mathrm{Ga}$ (at either $M$ or $T$ sites) probably also play a role.

\section{Unnamed Be-free analogue of surinamite}

Christy and Putnis (1988) reported one-cell wide layers having the surinamite structure in TEM images of sapphirine from Finero, Italy, in which the $1 A, 2 M$ and $4 M$ polytypes are present. The surinamite-like lamellae are attributed to $\mathbf{b} / 5$ stacking faults on (010), along which every fourth spinel-like layer is missing, i.e. $<$ PSPSPSPS $>$ (4 sapphirine layers) becomes $<$ PPSPSPS $>$ (1 surinamite and 2 sapphirine layers). Christy and Putnis (1988) suggested $\mathrm{Mg}_{4} \mathrm{Al}_{2} \mathrm{O}\left[\mathrm{Si}_{3} \mathrm{Al}_{2} \mathrm{O}_{15}\right]$ as a structural formula for the surinamite layer; this formula is derived from the surinamite formula by replacing ${ }^{\mathrm{iv}} \mathrm{Be}$ with ${ }^{\mathrm{iv}} \mathrm{Al}$ and one ${ }^{\text {vi }} \mathrm{Al}$ with one vi $\mathrm{Mg}$.

\section{Acknowledgements}

We thank Daniel Barker for his unpublished analyses and notes on aenigmatite, Thomas Kunzmann for background information on the analyses reported in his thesis (Kunzmann, 1989) and Richard Price for permission to cite unpublished analyses of Mg-rich aenigmatite from Mt Kenya. We acknowledge the helpful assistance by William Birch, past secretary of the Commission on New Minerals, Nomenclature and Classification, International Mineralogical Association, in establishing the present working group on nomenclature. We appreciate the constructive comments on the original proposal by members of the Commission.

\section{References}

Abbott, M.J. (1967) Aenigmatite from the groundmass of a peralkaline trachyte. American Mineralogist, 52, 1895-1901.

Aleksandrov, S.M. and Troneva, M.A. (2006) Composition, mineral assemblages and genesis of serendibite-bearing magnesian skarns. Geokhimiya, 2006(7), 722-738 (English translation:
Geochemistry International, 44(7), 665-680).

Alletti, M., Pompilio, M. and Rotolo, S.G. (2005) Mafic and ultramafic enclaves in Ustica Island lavas: Inferences on composition of lower crust and deep magmatic processes. Lithos, 84, 151-167.

Arakcheeva, A.V. (1995) Crystal structure of the baykovite mineral. Crystallography Reports, 40, 220-227.

Arakcheeva, A.V. and Ivanov, I.T. (1993) Crystal structure of disomatic phase of variable composition $\mathrm{CaAl}\left(\mathrm{Al}, \mathrm{V}, \mathrm{M}^{\mathrm{I}}\right)_{2}\left(\mathrm{~V}, \mathrm{M}^{\mathrm{II}}\right)(\mathrm{Si}, \mathrm{Al})_{2} \mathrm{O}_{10}$, where $\mathrm{M}^{\mathrm{I}}=\mathrm{Mg}$, $\mathrm{M}^{\mathrm{II}}=\mathrm{Al}, \mathrm{Fe}, \mathrm{Mn}, \mathrm{Ti}, \mathrm{Mg}$ : its polytypic modifications and structural homologs. Kristallografiya, 38, 144-161 (in Russian).

Arakcheeva, A.V., Karpinskii, O.G. Lyadova, V.Ya. (1991) Crystal structure of a $\mathrm{CaFe}_{3} \mathrm{AlO}_{7}$ aluminum-calcium ferrite of variable composition. Soviet Physics, Crystallography, 36, 332-336.

Åsheim, A., Berge, S.A., and Larsen, A.O. (2008) Sporelementer i ænigmatitt fra Larvik plutonkompleks. Norsk Bergverksmuseum, Skrift, 38, 63-65 (in Norwegian).

Avanzinelli, R., Bindi, L., Menchetti. S. and Conticelli, S. (2004) Crystallisation and genesis of peralkaline magmas from Pantelleria Volcano, Italy: an integrated petrological and crystal-chemical study. Lithos, 73, 41-69.

Baba, S., Grew, E.S., Shearer, C.K. and Sheraton, J.W. (2000) Surinamite: A high-temperature metamorphic beryllosilicate from Lewisian sapphirine-bearing kyanite-orthopyroxene-quartz-potassium feldspar gneiss at South Harris, N.W. Scotland. American Mineralogist, 85, 1474-1484.

Bancroft, G.M., Burns, R.G. and Stone, A.J. (1968) Applications of the Mössbauer effect to silicate mineralogy-II. Iron silicates of unknown and complex crystal structures. Geochimica et Cosmochimica Acta, 32, 547-559.

Barbier, J. (1990) $\mathrm{Mg}_{4} \mathrm{Ga}_{8} \mathrm{Ge}_{2} \mathrm{O}_{20}$, a new synthetic analog of the mineral sapphirine. Physics and Chemistry of Minerals, 17, 246-252.

Barbier, J. (1995) Structure refinement of $\mathrm{Na}_{2}(\mathrm{Mg}, \mathrm{Fe})_{6}\left[(\mathrm{Ge}, \mathrm{Fe})_{6} \mathrm{O}_{18}\right] \mathrm{O}_{2}$, a new aenigmatiteanalog. Zeitschrift für Kristallographie, 210, 19-23.

Barbier, J. (1996) Surinamite analogs in the $\mathrm{MgO}-\mathrm{Ga}_{2} \mathrm{O}_{3}-\mathrm{GeO}_{2}$ and $\mathrm{MgO}-\mathrm{Al}_{2} \mathrm{O}_{3}-\mathrm{GeO}_{2}$ systems. Physics and Chemistry of Minerals, 23, $151-156$.

Barbier, J. (1998) Crystal structures of sapphirine and surinamite analogues in the $\mathrm{MgO}-\mathrm{Ga}_{2} \mathrm{O}_{3}-\mathrm{GeO}_{2}$ system. European Journal of Mineralogy, 10, 1283-1293.

Barbier, J. and Hyde, B.G. (1988) Structure of sapphirine: its relation to the spinel, clinopyroxene and $\beta$-gallia structures. Acta Crystallographica, B44, 373-377.

Barbier, J., Grew, E.S., Moore, P.B. and Su, S.-C. (1999) 
Khmaralite, a new beryllium-bearing mineral related to sapphirine: A superstructure resulting from partial ordering of $\mathrm{Be}, \mathrm{Al}$ and $\mathrm{Si}$ on tetrahedral sites. American Mineralogist, 84, 1650-1660.

Barbier, J., Grew, E.S., Hålenius, E., Hålenius, U. and Yates, M.G. (2002) The role of Fe and cation order in the crystal chemistry of surinamite, $\left(\mathrm{Mg}, \mathrm{Fe}^{2+}\right)_{3}\left(\mathrm{Al}, \mathrm{Fe}^{3+}\right)_{3} \mathrm{O}\left[\mathrm{AlBeSi}{ }_{3} \mathrm{O}_{15}\right]:$ A crystal structure, Mössbauer spectroscopic, and optical spectroscopic study. American Mineralogist, 87, 501-513.

Barker, D.S. and Hodges, F.N. (1977) Mineralogy of intrusions in the Diablo Plateau, northern TransPecos magmatic province, Texas and New Mexico. Geologocal Society of America Bulletin, 88, $1428-1436$.

Birkett, T.C., Trzcienski, W.E., Jr. and Stirling, J.A.R. (1996) Occurrence and compositions of some Tibearing minerals in the Strange Lake intrusive complex, Quebec-Labrador boundary. The Canadian Mineralogist, 34, 779-801.

Bischoff, A., Geiger, T., Palme, H., Spettel, B., Schultz, L., Scherer, P., Schlüter, J. and Lkhamsuren, J. (1993) Mineralogy, chemistry, and noble gas contents of Adzhi-Bogdo-an LL3-6 chondritic breccia with L-chondritic and granitoidal clasts. Meteoritics, 28, 570-578.

Bøggild, O.B. (1953) The mineralogy of Greenland. Meddelelser om Grønland, 149(3), 442 pp.

Bohrson, W.A. and Reid, M.R. (1997) Genesis of silicic peralkaline volcanic rocks in an ocean island setting by crustal melting and open-system processes: Socorro Island, Mexico. Journal of Petrology, 38, 1137-1166.

Boivin, P. (1980) Données expérimentales préliminaires sur la stabilité de la rhönite à 1 atmosphère. Application aux gisements naturels. Bulletin de Minéralogie, 103, 491-502.

Bonaccorsi, E., Merlino, S. and Pasero, M. (1989) The crystal structure of the meteoritic mineral krinovite, $\mathrm{NaMg}_{2} \mathrm{CrSi}_{3} \mathrm{O}_{10}$. Zeitschrift für Kristallographie, 187, 133-138.

Bonaccorsi, E., Merlino, S., and Pasero, M. (1990) Rhönite: structural and microstructural features, crystal chemistry and polysomatic relationships. European Journal of Mineralogy, 2, 203-218.

Borley, G.D. (1976) Ænigmatite from an ægirine-riebeckite granite, Liruei Complex, Nigeria. Mineralogical Magazine, 40, 595-598.

Breithaupt, A. (1865) Mineralogische Studien. 29. Kölbingit. A inigmatit. Berg-und Huettenmoennische Zeitung, 24(47), 397-398.

Brigida, C., Poli, S. and Valle, M. (2007) Hightemperature phase relations and topological constraints in the quaternary system $\mathrm{MgO}-\mathrm{Al}_{2} \mathrm{O}_{3}-\mathrm{SiO}_{2}$ $\mathrm{Cr}_{2} \mathrm{O}_{3}$ : An experimental study. American
Mineralogist, 92, 735-747.

Brögger, W.C. (1887) Forelöbig meddelelse om mineralerne på de sydnorske augit- og nefelinsyeniters grovkornige gange. Geologiska Föreningens $i$ Stockholm Förhandlingar, 9, 247-274 (in Danish).

Brögger, W.C. (1890) Mineralien der südnorweg. Augitsyenite. 50. Ainigmatit, Breithaupt (Kölbingit, Breithaupt). Zeitschrift für Krystallographie und Mineralogie, 16, 423-433.

Brooks, C.K., Pedersen, A.K. and Rex, D.C. (1979) The petrology and age of alkaline mafic lavas from the nunatak zone of central East Greenland. Grønlands Geologiske Undersøgelse Bulletin, 133, 28pp.

Bryan, W.B. (1969) Alkaline and peralkaline rocks of Socorro Island, Mexico. Year Book - Carnegie Institution of Washington, 68, 194-200.

Bryan, W.B. and Stevens, N.C. (1973) Holocrystalline pantellerite from Mt. Ngun-Ngun, Glass House Mountains, Queensland, Australia. American Journal of Science, 273, 947-957.

Buerger, M.J. and Venkatakrishnan, V. (1974) Serendibite, a complicated, new, inorganic crystal structure. Proceedings of the National Academy of Sciences of the United States of America, 71, 4348-4351.

Bulakh, A.G. (1997) Mineralogy of alkaline granites of Gremyakha Tundra on the Kola Peninsula. Vestnik Sankt-Peterburgskogo Universiteta, Seriya 7, Geologiya, Geografiya, 1997(3), 18-28 (in Russian).

Burns, R.G. (1993) Mineralogical Applications of Crystal Field Theory, second edition, Cambridge University Press, Cambridge, UK, 551pp.

Burns, R.G. and Solberg, T.C. (1990) ${ }^{57}$ Fe-bearing oxide, silicate, and aluminosilicate minerals. Crystal structure trends in Mossbauer spectra. Pp. 262-283 in: (L.M. Coyne, S.W.S. McKeever and D.F. Blake, editors). Spectroscopic Characterization of Minerals and their Surfaces, ACS Symposium Series 415, American Chemical Society, Washington, D.C.

Burt, D.M. (1994) Vector representation of some mineral compositions in the aenigmatite group, with special reference to høgtuvaite. The Canadian Mineralogist, 32, 449-457.

Burt, J.B., Downs, R.T. and Costin, G. (2007) Singlecrystal X-ray refinement of wilkinsonite, $\mathrm{Na}_{2} \mathrm{Fe}_{4}^{2+} \mathrm{Fe}_{2}^{3+} \mathrm{Si}_{6} \mathrm{O}_{20}$. Acta Crystallographicn Section E, Structure Reports Online, 63, i122-i124.

Cameron, K.L., Carman, M.F. and Butler, J.C. (1970) Rhönite from Big Bend National Park, Texas. American Mineralogist, 55, 864-874.

Cannillo, E., Mazzi, F., Fang, J.H., Robinson, P.D. and Ohya, Y. (1971) The crystal structure of aenigmatite. American Mineralogist, 36, 427-446.

Carmichael, I.S.E. (1962) Pantelleritic liquids and their phenocrysts. Mineralogical Magazine, 33, 86-113. 
Chesnokov B.V., Vilisov, V.A, Bazhenova, L. F., Bushmakin A.F. and Kotlyarov, V.A. (1993). New minerals from the burned dumps of the Chelyabinsk coal basin (fifth communication). Ural Mineralogical Collection, 2, 3-8 (in Russian).

Chesnokov B.V., Vilisov, V.A, Bushmakin A.F., Kotlyarov, V.A. and Belogub, V.A. (1994). New minerals from the burned dumps of the Chelyabinsk coal basin (sixth communication). Ural Mineralogical Collection, 3, 15-19 (in Russian).

Choi, J.B. (1983) Mössbauer spectroscopy and crystal chemistry of aenigmatites. MS Thesis, Massachusetts Institute of Technology, Cambridge, Mass., 59pp.

Choi, J.B. and Burns, R.G. (1983) Crystal chemistry of aenigmatite and related minerals: results from Mossbauer spectroscopy. Abstracts with Programs, Geological Society of America, 15, 543.

Christy, A.G. (1988) A new $2 c$ superstructure in beryllian sapphirine from Casey Bay, Enderby Land, Antarctica. American Mineralogist, 73, 1134-1137.

Christy, A.G. (1989) The effect of composition, temperature and pressure on the stability of the $1 \mathrm{Tc}$ and $2 \mathrm{M}$ polytypes of sapphirine. Contributions to Mineralogy and Petrology, 103, 203-215.

Christy, A.G. and Putnis, A. (1988) Planar and line defects in the sapphirine polytypes. Physics and Chemistry of Minerals, 15, 548-558.

Christy, A.G., Phillips, B.L., Güttler, B.K. and Kirkpatrick, R.J. (1992) A ${ }^{27} \mathrm{Al}$ and ${ }^{29} \mathrm{Si}$ MAS NMR and infrared spectroscopic study of Al-Si ordering in natural and synthetic sapphirine. American Mineralogist, 77, 8-18.

Christy, A.G., Tabira, Y., Hölscher, A., Grew, E. S. and Schreyer, W. (2002) Synthesis of beryllian sapphirine in the system $\mathrm{MgO}-\mathrm{BeO}-\mathrm{Al}_{2} \mathrm{O}_{3}-\mathrm{SiO}_{2}-\mathrm{H}_{2} \mathrm{O}$ and comparison with naturally occurring beryllian sapphirine and khmaralite. Part 1: Experiments, TEM and XRD. American Mineralogist, 87, 1104-1112.

Corsaro, R.A., Miraglia, L. and Pompilio, M. (2007) Petrologic evidence of a complex plumbing system feeding the July-August 2001 eruption of Mt. Etna, Sicily, Italy. Bulletin of Volcanology, 69, 401-421.

Cosca, M.A., Rouse, R.R. and Essene, E.J. (1988) Dorrite $\left[\mathrm{Ca}_{2}\left(\mathrm{Mg}_{2} \mathrm{Fe}_{4}^{3+}\right)\left(\mathrm{Al}_{4} \mathrm{Si}_{2}\right) \mathrm{O}_{20}\right]$, a new member of the aenigmatite group from a pyrometamorphic melt-rock. American Mineralogist, 73, 1440-1448.

Curtis, L.W. and Currie, K.L. (1981) Geology and petrology of the Red Wine alkaline complex, central Labrador. Geological Survey Canada Bulletin, 294, $61 \mathrm{pp}$.

Dawson, J.B. (1997) Neogene-recent rifting and volcanism in northern Tanzania: relevance for comparisons between the Gardar Province and the East African Rift valley. Mineralogical Magazine,
61, 543-548.

Dawson, J.B., Harley, S.L., Rudnick, R.L. and Ireland, T.R. (1997) Equilibration and reaction in Archaean quartz-sapphirine granulite xenoliths from the Lace kimberlite pipe, South Africa. Journal of Metamorphic Geology, 15, 253-266.

Deer, W.A., Howie, R.A. and Zussman, J. (1978) Rockforming minerals, volume $2 A$, Single-chain silicates, second edition. Longman, London. 668 pp.

de Roever, E.W.F. (1973) Preliminary note on coexisting sapphirine and quartz in a mesoperthite gneiss from Bakhuis Mountains (Suriname). Geologisch Mijnbouwkundige Dienst van Suriname Mededeling, 22, 67-70.

de Roever, E.W.F, Kleft, C., Murray, E., Klein, E. and Drucker, W.H. (1976) Surinamite, a new Mg-Al silicate from the Bakhuis Mountains, western Surinam. I. Description, occurrence, and conditions of formation. American Mineralogist, 61, 193-197.

de Roever, E.W.F., Lattard, D. and Schreyer, W. (1981) Surinamite: A beryllium-bearing mineral. Contributions to Mineralogy and Petrology, 76, $472-473$.

Dornberger-Schiff, K. and Merlino, S. (1974) Order-disorder in sapphirine, aenigmatite and aenigmatite-like minerals. Acta Crystallographica, A30, 168-173.

Downes, H., Vaselli, O., Seghedi, I., Ingram, G., Rex, D., Coradossi, N., Pécskay, Z. and Pinarelli, L. (1995) Geochemistry of late Cretaceous-early Tertiary magmatism in Poiana Rusca (Romania). Acta Vulcanologica, 7(2), 209-217.

Downs, R.T. (2006) The RRUFF Project: an integrated study of the chemistry, crystallography, Raman and infrared spectroscopy of minerals. Program and Abstracts, $19^{\text {th }}$ General Meeting of the International Mineralogical Association, Kobe, Japan, p. 117 (http://rruff.info/, website viewed on 12 November 2008)

Duggan, M.B. (1990) Wilkinsonite, $\mathrm{Na}_{2} \mathrm{Fe}_{4}^{2+} \mathrm{Fe}_{2}^{3+} \mathrm{Si}_{6} \mathrm{O}_{20}$, a new member of the aenigmatite group from the Warrumbungle Volcano, New South Wales, Australia. American Mineralogist, 75, 694-701.

Ernst, W.G. (1962) Synthesis, stability relations, and occurrence of riebeckite and riebeckite-arfvedsonite solid solutions. Journal of Geology, 70, 689-736.

Ewart, A., Taylor, S.R. and Capp, A.C. (1968) Geochemistry of the pantellerites of Mayor Island, New Zealand. Contributions to Mineralogy and Petrology, 17, 116-140.

Farges. F., Brown, G.E., Jr. and Velde, D. (1994) Structural environment of $\mathrm{Zr}$ in two inosilicates from Cameroon: Mineralogical and geochemical implications. American Mineralogist, 79, 838-847.

Ferguson, A.K. (1978) A mineralogical investigation of some trachytic lavas and associated pegmatoids from 
Camel's Hump and Turritable Falls, central Victoria. Journal of the Geological Society of Australia, 25, 185-197.

Fleet, S.G. (1967) Non-space-group absences in sapphirine. Mineralogical Magazine, 36, 449-450.

Fleischer, M. (1936) The formula of aenigmatite. American Journal of Science, 232, 343-348.

Fleischer, M. (1964) New Mineral Names. American Mineralogist, 49, 816-821.

Fodor, R.V. and Hanan, B.B. (2000) Geochemical evidence for the Trindade hotspot trace: Columbia seamount ankaramite. Lithos, 51, 293-304.

Foerstner, H. (1881) Ueber Cossyrit, ein Mineral aus den Liparitlaven der Insel Pantellaria. Zeitschrift für Krystallographie und Mineralogie, 5, 348-362.

Foit, F.F., Jr., Hooper, R.L. and Rosenberg, P.E. (1987) An unusual pyroxene, melilite, and iron oxide mineral assemblage in a coal-fire buchite from Buffalo, Wyoming. American Mineralogist, 72, 137-147.

Friend, C.R.L. (1982) $\mathrm{Al}-\mathrm{Cr}$ substitution in peraluminous sapphirines from the Bjørnesund area, Fiskenaesset region, southern West Greenland. Mineralogical Magazine, 46, 323-328.

Fuchs, L.H. (1971) Occurrence of wollastonite, rhönite, and andradite in the Allende meteorite. American Mineralogist, 56, 2053-2068.

Fuchs, L.H. (1978) The mineralogy of a rhönite-bearing calcium aluminum rich inclusion in the Allende meteorite. Meteoritics, 13, 73-88.

Gaeta, M. and Mottana, A. (1991) Phase relations of aenigmatite minerals in a syenitic ejectum, Wonchi volcano, Ethiopia. Mineralogical Magazine, 55, $529-534$.

Gaines, R.V., Skinner, H.C.W., Foord, E.E., Mason, B., Rosenzweig, A., King, V.T. and Dowty, E. (1997) Dana's New Mineralogy: The System of Mineralogy of James Dwight Dana and Edward Salisbury Dana, eighth edition. Wiley, New York, 1819pp.

Gamble, J.A. and Kyle, P.R. (1987) The origins of glass and amphibole in spinel-wehrlite xenoliths from Foster Crater, McMurdo Volcanic Group, Antarctica. Journal of Petrology, 28, 755-779.

Gasparik, T., Parise, J.B., Reeder, R.J., Young, V.G. and Wilford, W.S. (1999) Composition, stability, and structure of a new member of the aenigmatite group, $\mathrm{Na}_{2} \mathrm{Mg}_{4+\mathrm{x}} \mathrm{Fe}_{2-2 \mathrm{x}}^{3+} \mathrm{Si}_{6+\mathrm{x}} \mathrm{O}_{20}$, synthesized at 13-14 GPa. American Mineralogist, 84, 257-266.

Gibb, F.G.F. and Henderson, C.M.B. (1996) The Shiant Isles Main Sill: structure and mineral fractionation trends. Mineralogical Magazine, 60, 67-97.

Gnos, E. and Kurz, D. (1994) Sapphirine-quartz and sapphirine-corundum assemblages in metamorphic rocks associated with the Semail Ophiolite (United Arab Emirates). Contributions to Mineralogy and Petrology, 116, 398-410.
Godard, G. and Mabit, J.-L. (1998) Peraluminous sapphirine formed during retrogression of a kyanite-bearing eclogite from Pays de Léon, Armorican Massif, France. Lithos, 43, 15-29.

Goßner, B. and Mußgnug, F (1928) Vergleichende röntgenographische Untersuchung von Magnesiumsilikaten. Neues Jahrbuch für Mineralogie, Geologie und Paläontologie Monatshefte Abteilung A, 58, 213-252.

Goßner, B. and Mußgnug, F. (1929) Über den Änigmatit und seine Stellung im System der Silikate. Centralblatt der Mineralogie, Geologie und Paläontologie, Abteilung A, Mineralogie und Petrographie, 1929, 5-11.

Grapes, R., Yagi, K. and Okumura, K. (1979) Aenigmatite, sodic pyroxene, arfvedsonite and associated minerals in syenites from Morotu, Sakhalin. Contributions to Mineralogy and Petrology, 69, 97-103.

Grapes, R.H., Wysoczanski, R.J. and Hoskin, P.W.O. (2003) Rhönite paragenesis in pyroxenite xenoliths, Mount Sidley volcano, Marie Byrd Land, West Antarctica. Mineralogical Magazine, 67, 639-651.

Grauch, R.I., Lindahl, I., Evans, H.T., Jr., Burt, D.M., Fitzpatrick, J.J., Foord, E.E., Graff, P.-R. and Hysingjord, J. (1994) Høgtuvaite, a new beryllian member of the aenigmatite group from Norway, with new X-ray data on aenigmatite. The Canadian Mineralogist, 32, 439-448.

Grew, E.S. (1981) Surinamite, taaffeite, and beryllian sapphirine from pegmatites in granulite-facies rocks in Casey Bay, Enderby Land, Antarctica: American Mineralogist, 66, 1022-1033.

Grew, E.S. (1986) Petrogenesis of kornerupine at Waldheim (Sachsen), German Democratic Republic. Zeitschrift für Geologische Wissenschaften (Berlin), 14, 525-558.

Grew, E.S. (1996) Borosilicates (exclusive of tourmaline) and boron in rock-forming minerals in metamorphic environments. Pp. 387-502. in: Boron: Mineralogy, Petrology, and Geochemistry. (E.S. Grew and L.M. Anovitz, editors). Reviews in Mineralogy, 33, Mineralogical Society of America, Washington, D.C.

Grew, E.S. (2002) Beryllium in metamorphic environments (emphasis on aluminous compositions). Pp. 487-549 in: Beryllium: Mineralogy, Petrology, and Geochemistry. (E.S. Grew, editor). Reviews in Mineralogy and Geochemistry, 50. Mineralogical Society of America, Washington, D.C.

Grew, E.S., Belakovskiy, D.I. and Leskova, N.V. (1988) Phase equilibria in talc-kyanite-hornblende rocks (with andalusite and sillimanite) from Kugi-Lal, southwestern Pamirs. Doklady Akademii Nauk SSSR, 299, 1222-1226 (in Russian).

Grew, E.S., Chernosky, J.V., Werding, G., Abraham, K., 
Marquez, N. and Hinthorne, J.R. (1990) Chemistry of kornerupine and associated minerals, a wet chemical, ion microprobe, and X-ray study emphasizing $\mathrm{Li}, \mathrm{Be}, \mathrm{B}$ and $\mathrm{F}$ contents. Journal of Petrology, 31; 1025-1070.

Grew, E.S., Pertsev, N.N., Boronikhin, V.A., Borisovskiy, S.Ye., Yates, M.G. and Marquez, N. (1991a) Serendibite in the Tayozhnoye deposit of the Aldan Shield, eastern Siberia, U.S.S.R. American Mineralogist, 76, 1061-1080.

Grew, E.S., Yates, M.G., Beryozkin, V.I. and Kitsul, V.I. (1991b) Kornerupine in slyudites from the Usmun River Basin in the Aldan Shield. II. Chemistry of the minerals, mineral reactions. Geologiya $i$ Geofizika, 1991(7), 99-116 (English translation: Soviet Geology and Geophysics, 32(7), 85-98).

Grew, E.S., Yates, M.G., Romanenko, I.M., Christy, A. G. and Swihart, G.H. (1992) Calcian, borian sapphirine from the serendibite deposit at Johnsburg, N. Y., USA. European Journal of Mineralogy, 4, 475-485.

Grew, E.S., Pertsev, N.N., Yates, M.G., Christy, A.G., Marquez, N. and Chernosky, J.V. (1994) Sapphirine+forsterite and sapphirine+humite-group minerals in an ultra-magnesian lens from Kuhai-lal, SW Pamirs, Tajikistan: are these assemblages forbidden? Journal of Petrology, 35, 1275-1293.

Grew, E.S., Yates, M.G., Barbier, J., Shearer, C.K., Sheraton, J.W., Shiraishi, K. and Motoyoshi, Y. (2000) Granulite-facies beryllium pegmatites in the Napier Complex in Khmara and Amundsen Bays, western Enderby Land, East Antarctica. Polar Geoscience, 13, 1-40.

Grew, E.S., Hålenius, U., Kritikos, M. and Shearer, C.K. (2001) New data on welshite, e.g. $\mathrm{Ca}_{2} \mathrm{Mg}_{3.8} \mathrm{Mn}_{0.6}^{2+} \mathrm{Fe}_{0.1}^{2+} \mathrm{Sb}_{1.5}^{5+} \mathrm{O}_{2}\left[\mathrm{Si}_{2.8} \mathrm{Be}_{1.7} \mathrm{Fe}_{0.65}^{3+} \mathrm{Al}_{0.7}\right.$ $\left.\mathrm{As}_{0.17} \mathrm{O}_{18}\right]$, an aenigmatite-group mineral. Mineralogical Magazine, 65, 665-674.

Grew, E.S., Barbier, J., Britten, J., Yates, M.G., Polyakov, V.O., Shcherbakova, E.P., Hålenius, U. and Shearer, C.K. (2005) Makarochkinite, $\mathrm{Ca}_{2} \mathrm{Fe}_{4}^{2+} \mathrm{Fe}^{3+} \mathrm{TiSi}_{4} \mathrm{BeAlO}_{20}$, a new beryllosilicate member of the aenigmatite-sapphirine-surinamite group from the Il'men Mountains (southern Urals), Russia. American Mineralogist, 90, 1402-1412.

Grew, E.S., Yates, M.G., Shearer, C.K., Hagerty, J.J., Sheraton, J.W. and Sandiford, M. (2006) Beryllium and other trace elements in paragneisses and anatectic veins of the ultrahigh-temperature Napier Complex, Enderby Land, East Antarctica: the role of sapphirine. Journal of Petrology, 47, 859-882.

Grew, E.S., Barbier, J., Britten, J., Hålenius, U. and Shearer, C.K. (2007) The crystal chemistry of welshite, a non-centrosymmetric $(P 1)$ aenigmatitesapphirine-surinamite group mineral. American
Mineralogist, 92, 80-90.

Grew, E.S., Hålenius, U. and Pasero, M. (2008) The crystal-chemistry of aenigmatite revisited: electron microprobe data, structure refinement and Mössbauer spectroscopy of aenigmatite from Vesterøya (Norway). European Journal of Mineralogy, 20, 983-991.

Groth, P. (1883) Footnote. Zeitschrift für Krystallographie und Mineralogie, 7, 607.

Grünhagen, H. and Seck, H.A. (1972) Rhönit aus einem Melaphonolith vom Puy de Saint-Sandoux (Auvergne). Tschermaks Mineralogische und Petrographische Mitteilungen, 18, 17-38.

Hamilton, J.D.G., Hoskins, B.F., Mumme, W.G., Borbidge, W.E. and Montague, M.A. (1989) The crystal structure and crystal chemistry of $\mathrm{Ca}_{2.3} \mathrm{Mg}_{0.8} \mathrm{Al}_{1.5} \mathrm{Si}_{1.1} \mathrm{Fe}_{8.3} \mathrm{O}_{20}$ (SFCA): solid solution limits and selected phase relationships of SFCA in the $\mathrm{SiO}_{2}-\mathrm{Fe}_{2} \mathrm{O}_{3}-\mathrm{CaO}\left(-\mathrm{Al}_{2} \mathrm{O}_{3}\right)$ system. Neues Jahrbuch fur Mineralogie Abhandlungen, 161, 1-26.

Harley, S.L. and Christy, A.G. (1995) Titanium-bearing sapphirine in a partially melted aluminous granulite xenolith, Vestfold Hills, Antarctica: geological and mineralogical implications. European Journal of Mineralogy, 7, 637-653.

Hatert, F. and Burke, E.A.J. (2008) The IMA-CNMNC dominant-constituent rule revisited and extended. The Canadian Mineralogist, 46, 717-728.

Havette, A., Clocchiatti, R., Nativel, P. and Montaggioni, L.F. (1982) Une paragenèse inhabituelle à fassaïte, mélilite et rhönite dans un basalte alcalin contaminé au contact d'un récif corallien (Saint-Leu, Ile de la Réunion). Bulletin de Minéralogie, 105, 364-375.

Hawthorne, F.C. and Oberti, R. (2006) On the classification of amphiboles. The Canadian Mineralogist, 44, 1-21.

Henderson, C.M.B., Pendlebury. K. and Foland, K.A. (1989) Mineralogy and petrology of the Red Hill alkaline igneous complex, New Hampshire, U.S.A. Journal of Petrology, 30, 627-666.

Higgins, J.B. and Ribbe, P.H. (1979) Sapphirine II. A neutron and $\mathrm{X}$-ray diffraction study of $(\mathrm{Mg}-\mathrm{Al})^{\mathrm{VI}}$ and $(\mathrm{Si}-\mathrm{Al})^{\mathrm{IV}}$ ordering in monoclinic sapphirine. Contributions to Mineralogy and Petrology, 68, 357-368.

Higgins, J.B., Ribbe, P.H. and Herd, R.K. (1979) Sapphirine I. Crystal chemical contributions. Contributions to Mineralogy and Petrology, 68, 349-356.

Hodges, F.N. and Barker, D.S. (1973) Solid solution in aenigmatite. Year Book - Carnegie Institution of Washington, 72, 578-581.

Howie, R.A. and Walsh, J.N. (1981) Riebeckitic arfvedsonite and aenigmatite from the Ailsa Craig microgranite. Scottish Journal of Geology, 17, 
$123-128$

Hurai, V., Huraiová, M., Konečny, P. and Thomas, R. (2007) Mineral-melt-fluid composition of carbonatebearing cumulate xenoliths in Tertiary alkali basalts of southern Slovakia. Mineralogical Magazine, 71, $63-79$.

Ike, E.C. (1985) Postmagmatic arfvedsonite-aenigmatite paragenesis in the ring-dyke of the Burra Centre, Ningi-Burra complex, Nigeria. Journal of African Earth Sciences, 3, 101-105.

Ivanov, A.V., Kononkova, N.N., Yang, S.V., and Zolensky, M.E. (2003) The Kaidun Meteorite: Clasts of alkaline-rich fractionated materials. Meteoritics \& Planetary Science, 38, 725-737.

Jannot, S., Schiano, P. and Boivin, P. (2005) Melt inclusions in scoria and associated mantle xenoliths of Puy Beaunit Volcano, Chaîne des Puys, Massif Central, France. Contributions to Mineralogy and Petrology, 149, 600-612.

Johan, Z. and Oudin, E. (1986) Présence de grenats, $\left.\mathrm{Ca}_{3} \mathrm{Ga}_{2}\left(\mathrm{GeO}_{4}\right)_{3}, \mathrm{Ca}_{3} \mathrm{Al}_{2}[\mathrm{Ge}, \mathrm{Si}) \mathrm{O}_{4}\right]_{3}$ et d'un équivalent ferrifère, germanifère et gallifère de la sapphirine $\mathrm{Fe}_{4}(\mathrm{Ga}, \mathrm{Sn}, \mathrm{Fe})_{4}(\mathrm{Ga}, \mathrm{Ge})_{6} \mathrm{O}_{20}$, dans la blende des gisements de la zone axiale pyrénéenne. Conditions de formation des phases germanifères et gallifères. Compte Rendus de l'Académie des Sciences, Paris, 303, Series II, 811-816.

Johnsen, O., Ferraris, G., Gault, R.A., Grice, J.D., Kampf, A.R. and Pekov I.V. (2003) The nomenclature of eudialyte-group minerals. The Canadian Mineralogist, 41, 785-794.

Johnston, A.D. and Stout, J.H. (1984) A highly oxidized ferrian salite-, kennedyite-, forsterite-, and rhönitebearing alkali gabbro from Kauai, Hawaii and its mantle xenoliths. American Mineralogist, 69, 57-68.

Johnston, A.D. and Stout, J.H. (1985) Compositional variation of naturally occurring rhoenite. American Mineralogist, 70, 1211-1216.

Jones, A.P. (1984) Mafic silicates from the nepheline syenites of the Motzfeldt centre, South Greenland. Mineralogical Magazine, 48, 1-12.

Jørgensen, K.A. (1987) Mineralogy and petrology of alkaline granophyric xenoliths from the Thorsmörk ignimbrite, southern Iceland. Lithos, 20, 153-168.

Kamineni, D.C. and Rao, A.T. (1988) Sapphirinebearing quartzite from the eastern Ghats granulite terrain, Vizianagaram, India. Journal of Geology, 96, 209-220.

Kelsey, C.H. and McKie, D. (1964) The unit-cell of aenigmatite. Mineralogical Magazine, 33, 986-1001.

Krivdik, S.G. and Tkachuk, V.I. (1988) Aenigmatite first occurrence in Ukraine. Dopovidi Akademii Nauk Ukrainskoi RSR, Seriya B, Geologichni, khimichni ta biologichni nauky, 1988(8), 16-18 (in Ukrainian).
Krivovichev, S.V. and Armbruster, T. (2004) The crystal structure of jonesite, $\mathrm{Ba}_{2}(\mathrm{~K}, \mathrm{Na})\left[\mathrm{Ti}_{2}\left(\mathrm{Si}_{5} \mathrm{Al}\right) \mathrm{O}_{18}\right.$ $\left.\left(\mathrm{H}_{2} \mathrm{O}\right)\right]\left(\mathrm{H}_{2} \mathrm{O}\right)_{n}$ : A first example of titanosilicate with porous double layers. American Mineralogist, 89, 314-318.

Kuehner, S.M. and Irving, A.J. (2007) Primary ferric iron-bearing rhönite in plutonic igneous angrite NWA 4590: Implications for redox conditions on the angrite parent body. Eos, Transactions of the American Geophysical Union, 88(52), Fall Meeting Supplement, Abstract P41A-0219.

Kunzmann, T. (1989) Rhönit: Mineralchemie, Paragenese und Stabilität in alkalibasaltischen Vulkaniten (Ein Beitrag zur Minerogenese der Rhönit-Änigmatit-Mischkristallgruppe). Doctor's Dissertation, Ludwig-Maximilians-Universität, München, 152pp.

Kunzmann, T. (1999) The aenigmatite-rhönite mineral group. European Journal of Mineralogy, 11, 743-756.

Kuzel , H -J. (1961) Über Formel und Elementarzelle des Sapphirin. Neues Jahrbuch für Mineralogie Monatshefte, 1961, 68-71.

Kyle, P.R. and Price, R.C. (1975) Occurrences of rhönite in alkalic lavas of the McMurdo Volcanic Group, Antarctica, and Dunedin Volcano, New Zealand. American Mineralogist, 60, 722-725.

Larsen, L.M. (1977) Aenigmatites from the Ilímaussaq intrusion, south Greenland: Chemistry and petrological implications. Lithos, 10, 257-270.

Liati, A. and Seidel, E. (1994) Sapphirine and högbomite in overprinted kyanite-eclogites of central Rhodope, N. Greece: first evidence of granulitefacies metamorphism. European Journal of Mineralogy, 6, 733-738.

Lindsley, D.H. and Haggerty, S.E. (1970) Phase relations of $\mathrm{Fe}-\mathrm{Ti}$ oxides and aenigmatite; oxygen fugacity of the pegmatoid zones. Year Book Carnegie Institute of Washington, 69, 278-284.

Lorenzen, J. (1882) On some minerals from the sodalitesyenite in Juliane-haab district, south Greenland. Mineralogical Magazine, 5, 49-70.

Lorenzen, J. (1893) Undersølgelse af mineralier fra Grønland. 7. Saphirin. Meddelelser om Grønland, 7, 17-19 (in Danish).

Machin, M.P. and Süsse, P. (1974) Serendibite: a new member of the aenigmatite structure group. Nenes Jahrbuch für Mineralogie Monatshefte, 1974, 435-441.

Magonthier, M.C. and Velde, D. (1976) Mineralogy and petrology of some Tertiary leucite - rhönite basanites from central France. Mineralogical Magazine, 40, 817-826.

Mahood, G. A. and Stimac, J.A. (1990) Trace-element partitioning in pantellerites and trachytes. Geochimica et Cosmochimica Acta, 54, 2257-2276. 
Mao, H.K. and Bell, P.M. (1974) Crystal-field effects of trivalent titanium in fassaite from the Pueblo de Allende meteorite. Year Book - Carnegie Institution of Washington, 73, 488-492.

Marks, M. and Markl, G. (2003) Ilímaussaq 'en miniature': closed-system fractionation in an agpaitic dyke rock from the Gardar Province, South Greenland (contribution to the mineralogy of Ilímaussaq no. 117). Mineralogical Magazine, 67, 893-919.

Marsh, J.S. (1975) Aenigmatite stability in silicaundersaturated rocks. Contributions to Mineralogy and Petrology, 50, 135-144.

Mason, B. and Taylor, S.R. (1982) Inclusions in the Allende meteorite. Smithsonian Contributions to the Earth Sciences, 25, 30pp.

McKie, D. (1963) Order-disorder in sapphirine. Mineralogical Magazine, 33, 635-645.

Mercier, A., Debat, P. and Saul, J.M. (1999) Exotic origin of the ruby deposits of the Mangari area in SE Kenya. Ore Geology Reviews, 14, 83-104.

Merlino, S. (1970) Crystal structure of aenigmatite. Journal of the Chemical Society. Section D: Chemical Communications, 20, 1288-1289.

Merlino, S. (1972) X-ray crystallography of krinovite. Zeitschrift für Kristallographie, 136, 81-88.

Merlino, S. (1980) Crystal structure of sapphirine-1Tc. Zeitschrift für Kristallographie, 151, 91-100.

Merlino, S. and Pasero, M. (1987) Studio HRTEM della saffirina: relazioni tra politipi $1 \mathrm{Tc}$ e $2 \mathrm{M}$ e nuovo politipo 4M. Rendiconti della Società Italiana di Mineralogia e Petrologia., 42, 310 (in Italian).

Merlino, S. and Pasero, M. (1997) Merlino, S. and Pasero, M. (1997) Polysomatic approach in the crystal chemical study of minerals. Pp. 297-312 in: Modular Aspects of Minerals (S. Merlino, editor). European Mineralogical Union Notes in Mineralogy, 1,. Eőtvős University Press, Budapest.

Merlino, S. and Zvyagin, B.B. (1998) Modular features of sapphirine-type structures. Zeitschrift für Kristallographie, 213, 513-521.

Mitrofanov, F.P. and Afanas'yeva, L.I. (1966) Aenigmatite from alkalic syenite of the eastern Sayans. Doklady of the Academy of Sciences of the U.S.S.R., Earth Science Sections, 166, 111-113.

Moore, P.B. (1967) Eleven new minerals from Långban, Sweden. The Canadian Mineralogist, 9, 301 (abstract).

Moore, P.B. (1968) Crystal structure of sapphirine. Nature, 218, 81-82.

Moore, P.B. (1969) The crystal structure of sapphirine. American Mineralogist, 54, 31-49.

Moore, P.B. (1970) Mineralogy and chemistry of Långban-type deposits in Bergslagen, Sweden. Mineralogical Record, 1, 154-172.

Moore, P.B. (1976) Surinamite, a new Mg-Al silicate from the Bakhuis Mountains, western Surinam. II. X-ray crystallography and proposed crystal structure. American Mineralogist, 61, 197-199.

Moore, P.B. (1978) Welshite, $\mathrm{Ca}_{2} \mathrm{Mg}_{4} \mathrm{Fe}^{3+} \mathrm{Sb}^{5+} \mathrm{O}_{2}$ $\left[\mathrm{Si}_{4} \mathrm{Be}_{2} \mathrm{O}_{18}\right]$, a new member of the aenigmatite group. Mineralogical Magazine, 42, 129-132.

Moore, P.B. and Araki, T. (1983) Surinamite, ca. $\mathrm{Mg}_{3} \mathrm{Al}_{4} \mathrm{Si}_{3} \mathrm{BeO}_{16}$ : its crystal structure and relation to sapphirine, ca. $\mathrm{Mg}_{2.8} \mathrm{Al}_{7.2} \mathrm{Si}_{1.2} \mathrm{O}_{16}$. American Mineralogist, 68, 804-810.

Mumme, W.G. (1988) A note on the relationship of $\mathrm{Ca}_{2.3} \mathrm{Mg}_{0.8} \mathrm{Al}_{1.5} \mathrm{Si}_{1.1} \mathrm{Fe}_{8.3} \mathrm{O}_{20}$ (SFCA) with aenigmatite group minerals and sapphirine. Neues Jahrbuch für Mineralogie Monatshefte, 1988, 359-366.

Mumme, W.G. (2003) The crystal structure of SFCA-II, $\mathrm{Ca}_{5.1} \mathrm{Al}_{9.3} \mathrm{Fe}_{18.7}^{3+} \mathrm{Fe}_{0.9}^{2+} \mathrm{O}_{48}$ a new homologue of the aenigmatite structure-type, and structure refinement of SFCA-type, $\mathrm{Ca}_{2} \mathrm{Al}_{5} \mathrm{Fe}_{7} \mathrm{O}_{20}$. Implications for the nature of the 'ternary-phase solid-solution' previously reported in the $\mathrm{CaO}-\mathrm{Al}_{2} \mathrm{O}_{3}$-iron oxide system. Neues Jahrbuch für Mineralogie Abhandlungen, 178, 307-335.

Mumme, W.G., Clout, J.M.F. and Gable, R.W. (1998) The crystal structure of SFCA-I, $\mathrm{Ca}_{3.18} \mathrm{Fe}_{14.66}^{3+}$ $\mathrm{Al}_{1.34} \mathrm{Fe}_{0.82}^{2+} \mathrm{O}_{28}$, a homologue of the aenigmatite structure type, and new crystal structure refinements of $\beta$-CFF, $\mathrm{Ca}_{2.99} \mathrm{Fe}_{14.30}^{3+} \mathrm{Fe}_{0.55}^{2+} \mathrm{O}_{25}$ and $\mathrm{Mg}$-free SFCA, $\mathrm{Ca}_{2.45} \mathrm{Fe}_{9.04}^{3+} \mathrm{Al}_{1.74} \mathrm{Fe}_{0.16}^{2+} \mathrm{Si}_{0.6} \mathrm{O}_{20}$. Neues Jahrbuch für Mineralogie Abhandlungen, 173, 93-117.

Nash, W.P., Carmichael, I.S.E. and Johnson, R.W. (1969) The mineralogy and petrology of Mount Suswa, Kenya. Journal of Petrology, 10, 409-439.

Navrotsky, A. (1975) Thermochemistry of chromium compounds, especially oxides at high temperature. Geochimica et Cosmochimica Acta, 39, 819-832.

Nédli, Z. and Tóth, T.M. (2003) Petrography and mineral chemistry of rhönite in ocelli of alkali basalt from Villány Mts, SW Hungary. Acta MineralogicaPetrographica, Szeged, 44, 51-56.

Nicholls, J. and Carmichael, I.S.E. (1969) Peralkaline acid liquids: a petrologic study. Contributions to Mineralogy and Petrology, 20, 268-294.

Nickel, E.H. and Grice, J.D. (1998) The IMA Commission on New Minerals and Mineral Names: procedures and guidelines on mineral nomenclature, 1998. The Canadian Mineralogist, 36, 913-926.

Nicollet, C. (1990) Crustal evolution of the granulites of Madagascar. Pp. 291-310 in: D. Vielzeuf and P. Vidal, (editors). Granulites and Crustal Evolution, NATO Advanced Science Institutes Series, Kluwer, Dordrecht, Netherlands.

Nijland, T.G., Touret, J.L.R. and Visser, D. (1998) Anomalously low temperature orthopyroxene, spinel, and sapphirine occurrences in metasediments from the Bamble amphibolite-to-granulite facies transition zone (South Norway): possible evidence 
for localized action of saline fluids. Journal of Geology, 106, 575-590.

Nishio, F., Katsushima, T. and Ohmae, H. (1985) Volcanic ash layers in bare ice areas near the Yamato Mountains, Dronning Maud Land and the Allan Hills, Victoria Land, Antarctica. Annals of Glaciology, 7, 34-41.

Nkoumbou, C., Déruelle, B., and Velde, D. (1995) Petrology of Mt Etinde nephelinite series. Journal of Petrology, 36, 373-395.

Olsen, E. and Fuchs, L. (1968) Krinovite, $\mathrm{NaMg}_{2} \mathrm{CrSi}_{3} \mathrm{O}_{10}$ : a new meteorite mineral. Science, 161, 786-787.

Olsson, H. B. (1983) Rhönite from Skåne (Scania), southern Sweden. Geologiska Föreningen $i$ Stockholm Förhandlingar, 105, 281-286.

Owen, J.V., Greenough, J.D., Hy, C. and Ruffman, A. (1988) Xenoliths in a mafic dyke at Popes Harbour, Nova Scotia: implications for the basement to the Meguma Group. Canadian Journal of Earth Sciences, 25, 1464-1471.

Palache, C. (1933) Crystallographic notes on anapaite, ainigmatite and eudidymite. Zeitschrift für Kristallographie, Kristallogeometrie, Kristallophysik, Kristallochemie, 86, 280-291.

Peacor, D.R. (1968) The crystal structure of $\mathrm{CoGeO}_{3}$. Zeitschrift für Kristallographie, 126, 299-306.

Pertsev, N.N. and Nikitina, I.B. (1959) New data on serendibite. Zapiski Vsesoyuznogo Mineralogicheskogo Obshchestva, 88, 169-172 (in Russian).

Platt, R.G. and Woolley, A. R. (1986) The mafic mineralogy of the peralkaline syenites and granites of the Mulanje Complex, Malawi. Mineralogical Magazine, 50, 85-99.

Podlesskii, K.K., Aranovich, L. Ya., Gerya, T.V. and Kosyakova, N.A. (2008) Sapphirine-bearing assemblages in the system $\mathrm{MgO}-\mathrm{Al}_{2} \mathrm{O}_{3}-\mathrm{SiO}_{2}$ : A continuing ambiguity. European Journal of Mineralogy, 20, 721-734.

Polyakov, V.O., Cherepivskaya, G.Ye. and Shcherbakova, Ye.P. (1986) Makarochkinite - a new beryllosilicate. In New and little-studied minerals and mineral associations of the Urals. Akademiya Nauk SSSR Ural'skiy Nauchnyy Tsentr, Sverdlovsk, p. 108-110 (in Russian).

Powell, M. (1978) The crystallisation history of the Igdlerfigssalik nepheline syenite intrusion, Greenland. Lithos, 11, 99-120.

Prestvik, T., Torske, T., Sundvoll, B. and Karlsson, H. (1999) Petrology of early Tertiary nephelinites off mid-Norway. Additional evidence for an enriched endmember of the ancestral Iceland plume. Lithos, 46, 317-330.

Price, R.C., Johnson, R.W., Gray, C.M. and Frey, F.A. (1985) Geochemistry of phonolites and trachytes from the summit region of Mt. Kenya. Contributions to Mineralogy and Petrology, 89, 394-409.

Prior, G.T. and Coomaraswamy, A.K. (1903) Serendibite, a new borosilicate from Ceylon. Mineralogical Magazine, 13, 224-227.

Raade, G. and Larsen, A.O. (1980) Polylithionite from syenite pegmatite at Vøra, Sandefjord, Oslo region, Norway. Contributions to the mineralogy of Norway, No. 65. Norsk Geologisk Tidsskrift, 60, 117-124.

Redhammer, G.J., Roth, G., Topa, D. and Amthauer, G. (2008) Synthetic aenigmatite analog $\mathrm{Na}_{2}\left(\mathrm{Mn}_{5.26} \mathrm{Na}_{0.74}\right) \mathrm{Ge}_{6} \mathrm{O}_{20}$ : structure and crystal chemical considerations. Acta Crystallographica Section C, 64, i21-i26.

Ren, M., Omenda, P.A., Anthony, E.Y., White, J.C., Macdonald, R. and Bailey, D.K. (2006) Application of the QUILF thermobarometer to the peralkaline trachytes and pantellerites of the Eburru volcanic complex, East African Rift, Kenya. Lithos, 91, 109-124.

Ridolfi, F., Renzulli, A., Macdonald, R. and Upton, B.G.J. (2006) Peralkaline syenite autoliths from Kilombe Volcano, Kenya Rift valley: Evidence for subvolcanic interaction with carbonatitic fluids. Lithos, 91, 373-392.

Rondorf, A. (1989) Rhönit vom Vulkan Sattel bei Eich/ Osteifel. Der Aufschluss, 40, 391-401.

Rudneva, A.V. and Malysheva, T.Ya. (1960) The composition of baykovite. Doklady Akademii Nauk SSSR, 130, 1329-1332 (in Russian).

Sabau, G., Alberico, A. and Negulescu, E. (2002) Peraluminous sapphirine in retrogressed kyanitebearing eclogites from the South Carpathians: status and implications. International Geology Review, 44, 859-876.

Sahama, T.G., Lehtinen, M. and Rehtijärvi, P. (1974) Properties of sapphirine. Annales Academiae Scientiarum Fennicae, Series A3: GeologicaGeographica, 114, 24pp.

Sajeev, K. and Osanai, Y. (2004) Ultrahigh-temperature metamorphism $\left(1150^{\circ} \mathrm{C}, 12 \mathrm{kbar}\right)$ and multistage evolution of Mg-, Al-rich granulites from the central Highland Complex, Sri Lanka. Journal of Petrology, 45, $1821-1844$.

Savel'yeva, V.B., Ushchapovskaya, Z.F., Medvedeva, T.I., Chestnova, Ye.P. and Balyshev, S.O. (1995) Serendibite from skarns of the Ozyorskiy Massif (Western Baikal region). Zapiski Vserossiyskogo Mineralogicheskogo Obshchestva, 124(2), 87-98 (in Russian).

Semenov, Ye.I., Khomyakov, A.P. and Bykova, A.V. (1965) Magbasite, a new mineral. Doklady Akademii Nauk SSSR, 163, 718-719 (in Russian).

Shcherbakova, Ye.P., Bazhenov, A.G., and Valizer, N.I. (2004) How makarochkinite was discovered. Pp. 28-33. in: Polyakov's readings, Institute of 
Mineralogy, Miass, Russia (in Russian).

Schmetzer, K., Bosshart, G., Bernhardt, H.-J., Gübelin, E.J. and Smith, C.P. (2002) Serendibite from Sri Lanka. Gems \& Gemology, 38, 73-79.

Schreyer, W. and Abraham, K. (1975) Peraluminous sapphirine as a metastable reaction product in kyanite-gedrite-talc schist from Sar e Sang, Afghanistan. Mineralogical Magazine, 40, 171-180.

Sheng, Y.J., Hutcheon, I.D. and Wasserburg, G.J. (1991) Origin of plagioclase-olivine inclusions in carbonaceous chondrites. Geochimica et Cosmochimica Acta, 55, 581-599.

Sills, J.D, Ackermand, D., Herd, R.K. and Windley, B.F. (1983) Bulk composition and mineral parageneses of sapphirine-bearing rocks along a gabbro-lherzolite contact at Finero, Ivrea zone, N Italy. Journal of Metamorphic Geology, 1, 337-351.

Simon, G. and Chopin, C. (2001) Enstatite-sapphirine crack-related assemblages in ultrahigh-pressure pyrope megablasts, Dora-Maira Massif, western Alps. Contributions to Mineralogy and Petrology, 140, 422-440.

Simon, S.B., Davis, A.M. and Grossman, L. (1999) Origin of compact Type A refractory inclusions from CV3 carbonaceous chondrites. Geochimica et Cosmochimica Acta, 63, 1233-1248.

Soellner, J. (1907) Ueber Rhönit, ein neues änigmatitähnliches Mineral und über das Vorkommen und die Verbreitung desselben in basaltischen Gesteinen. Neues Jahrbuch für Mineralogie, Geologie und Paleaontologie Beilage-Band, 24, 475-547.

Soellner, J. (1909) Beiträge zur Kenntnis des Cossyrits von Pantelleria. Zeitschrift für Krystallographie und Mineralogie, 46, 518-562.

Steffen, G., Seifert, F. and Amthauer, G. (1984) Ferric iron in sapphirine: a Mössbauer spectroscopic study. American Mineralogist, 69, 339-348.

Stolz, A.J. (1986) Mineralogy of the Nandewar volcano, northeastern New South Wales, Australia. Mineralogical Magazine, 50, 241-255.

Stromeyer, F. (1819) 2. Saphirin von Fiskenaes oder Kikertarsoeitsiak. Pp. 1994-1995 in: Göttingische gelehrte Anzeigen unter der Aussicht der königlische Gesellschaft der Wissenschaften, Weidmannsche Buchhandlung, Berlin.

Stromeyer, F. (1821) XXVI. Untersuchung des Saphirins von Fiskanaes in Grönland. Pp. 391-398 in: Untersuchungen über die Mischung der Mineralkörper and anderer damit verwandten Substanzen. Vandenhoeck und Ruprecht, Göttingen, Germany.

Strunz, H. and Nickel, E.H. (2001) Strunz Mineralogical Tables. Chemical-Structural Mineral Classification System, Ninth Edition, Schweizerbart'sche Verlagsbuchhandlung, Stuttgart, Germany, 870pp.

Sugiyama, K., Monkawa, A. and Sugiyama, T. (2005)
Crystal structure of the SFCAM phase, $\mathrm{Ca}_{2}(\mathrm{Ca}, \mathrm{Fe}, \mathrm{Mg}, \mathrm{Al})_{6}(\mathrm{Fe}, \mathrm{Al}, \mathrm{Si})_{6} \mathrm{O}_{20}$. ISIJ International, 45, 560-568.

Süsse, P. (1968) Serendibite, space group and cell dimensions. Naturwissenschaften, 55, 176.

Tateishi, K., Tsunogae, T., Santosh, M. and Janardhan, A.S. (2004) First report of sapphirine+quartz assemblage from Southern India: implications for ultrahigh-temperature metamorphism. Gondwana Research, 7, 899-912.

Thompson, R.N. and Chisholm, J.E. (1969) Synthesis of aenigmatite. Mineralogical Magazine, 37, 253-255.

Timina, T. Yu., Sharyagin, V.V. and Golovin, A.V. (2006) Melt evolution during the crystallization of basanites of the Tergesh pipe, northern Minusinsk Depression. Geochemistry International, 44, 752-770.

Treiman, A.H. (2008) Rhönite in Luna 24 pyroxenes: First find from the Moon, and implications for volatiles in planetary magmas. American Mineralogist, 93, 488-491.

Ussing, N.V. (1889) Undersögelse af mineraler fra Fiskernæs i Grönland. 1. Sapphirin. Öfversigt af Kongliga Vetenskaps-Akademiens Förhandlingar, 46(1), 17-26 (in Danish).

Ussing, N.V. (1898) Aignigmatit. Kölbingit. Pp. 214-220 in: Mineralogisk-petrografiske Undersøgelser af Grønlandske Nefelinsyeniter og beslægtede Bjærgarter. Meddelelser om Grønland, 14, (in Danish).

Van Derveer, D.G., Swihart, G.H., Sen Gupta P.K. and Grew, E.S. (1993) Cation occupancies in serendibite: A crystal structure study. American Mineralogist, 78, 195-203.

Velde, D. (1978) An aenigmatite-richterite-olivine trachyte from Puu Koae, West Maui, Hawaii. American Mineralogist, 63, 771-778.

Vlasov, K.A., Kuz'menko, M.Z. and Es'kova, E.M. (1966) The Lovozero Alkali Massif. Hafner, New York, 627 pp.

Vogt, T. (1947) Mineral assemblages with sapphirine and kornerupine. Bulletin de la Commission Géologique de Finlande, 140, 15-24.

Walenta, K. (1969) Zur Kristallographie des Rhönits. Zeitschrift für Kristallographie, 130, 214-230.

Warren, P.H., Huber, H. and Ulff-Møller, F. (2006) Alkali-feldspathic material entrained in Fe,S-rich veins in a monomict ureilite. Meteoritics \& Planetary Science, 41, 797-813.

Warren, R.G. and Hensen, B.J. (1987) Peraluminous sapphirine from the Aileron district, Arunta Block, central Australia. Mineralogical Magazine, 51, 409-415.

White, J.C., Ren, M. and Parker, D.F. (2005) Variation in mineralogy, temperature, and oxygen fugacity in a suite of strongly peralkaline lavas and tuffs, 


\section{E. S. GREW ET AL.}

Pantelleria, Italy. The Canadian Mineralogist, 43, $1331-1347$.

Yagi, K. and Souther, J.G. (1974) Aenigmatite from Mt. Edziza, British Columbia, Canada. American Mineralogist, 59, 820-829.

Yakubovich, O.V., Malinovskii, Yu.A. and Polyakov, V.O. (1990) Crystal structure of makarochkinite. Kristallografiya, 35, 1388-1394 (English translation: Soviet Physics and Crystallography, 35, 818-822).

Yang H. and Konzett, J. (2000) High-pressure synthesis of $\mathrm{Na}_{2} \mathrm{Mg}_{6} \mathrm{Si}_{6} \mathrm{O}_{18}(\mathrm{OH})_{2}$ - a new hydrous silicate phase isostructural with aenigmatite. American Mineralogist, 85, 259-262.

Zies, E.G. (1966) A new analysis of cossyrite from the island of Pantelleria. American Mineralogist, 51, $200-205$.

Zolensky, M. and Ivanov, A. (2003) The Kaidun microbreccia meteorite: A harvest from the inner and outer asteroid belt. Chemie der ErdeGeochemistry, 63, 185-246.

Zvyagin, B.B. and Merlino, S. (2003) The pyroxenespinel polysomatic system. Zeitschrift für Kristallographie, 218, 210-220. 